Universidade de Brasília

Faculdade de Direito

Programa de Pós-Graduação em Direito - PPGD-UnB

\title{
TRANSCONSTITUCIONALISMO, DIREITO ISLÂMICO E LIBERDADE RELIGIOSA
}

\author{
Leonardo Almeida Lage
}

Brasília

Agosto - 2016 


\section{Leonardo Almeida Lage}

\section{Transconstitucionalismo, direito islâmico e liberdade religiosa}

Dissertação apresentada ao Programa de PósGraduação em Direito da Universidade de Brasília (PPGD-UnB), como requisito parcial à obtenção do grau de Mestre em Direito (Linha de Pesquisa: Constituição e Democracia).

Orientador: Professor Dr. Marcelo da Costa Pinto Neves Coorientador: Professor Dr. Maurizio Oliviero 
Leonardo Almeida Lage

Transconsitucionalismo, direito islâmico e liberdade religiosa

Dissertação apresentada ao Programa de PósGraduação em Direito da Universidade de Brasília (PPGD-UnB), como requisito parcial à obtenção do grau de Mestre em Direito (Linha de Pesquisa: Constituição e Democracia).

Brasília (DF), 19 de agosto de 2016.

Professor Dr. Marcelo da Costa Pinto Neves - FD/UnB

Orientador

Prof. Dr. Maurizio Oliviero - Università degli Studi di Perugia (Itália)

Membro da Banca Examinadora

Professora Dr. ${ }^{a}$ Claudia Rosane Roesler - FD/UnB

Membro da Banca Examinadora

Professora Dr. ${ }^{a}$ Debora Diniz - FD/UnB

Suplente 
À vovó loira 


\section{AGRADECIMENTOS}

Agradeço ao Professor Dr. Marcelo Neves, por toda a atenção, paciência e sensibilidade que dedicou a mim durante o período de elaboração deste trabalho. Além disso, agradeço-lhe pelas contribuições que deu nas reuniões de orientação, pelos comentários que propiciaram a lapidação de alguns pontos do texto e, sobretudo, pela inspiração que suas obras proporcionaram para minhas próprias inquietações e interesses acadêmicos.

Ao Professor Dr. Maurizio Oliviero, com cuja generosidade incrível tive o privilégio de contar ao longo dos últimos dois anos. Este trabalho não teria sido possível sem suas lições sobre o direito islâmico e sobre o constitucionalismo nos países do mundo islâmico, tampouco sem a interlocução enriquecedora que a coorientação oportunizou.

À Professora Dr. ${ }^{a}$ Claudia Rosane Roesler, pela preocupação, pelo incentivo e pelas conversas que ajudaram a pôr as ideias em ordem. Sou-lhe especialmente grato por sua amizade e por sua presença ao longo de toda minha trajetória acadêmica, desde que fui seu aluno na disciplina da graduação "Ética e Direito" (no longínquo ano de 2009), sempre com a mesma atenção, gentileza e inteligência que lhe são características.

Ao Professor Dr. Mohamed A. Arafa, cujas aulas no curso "Islamic Law and Comparative Middle Eastern Legal and Political Studies" proporcionaram uma aproximação com a realidade política e com as práticas jurídicas no Oriente Médio e no Norte da África que os livros sobre direito islâmico, por si sós, jamais poderiam suprir. Agradeço-lhe pelas recomendações de leitura, pela disposição para conversar sobre minhas dúvidas e pelo carisma com que conduziu todos os encontros.

Ao meu colega de mestrado e doutorando José Nunes de Cerqueira Neto, agradeço pela revisão do projeto de pesquisa.

Às minhas amigas e colegas de mestrado Sinara Gumieri, Gabriela Rondon e Bruna Costa, por todas as conversas sobre redação acadêmica e sobre estratégias de organização da pesquisa. Agradeço, em especial, à Gabriela e à Bruna, pela revisão parcial do texto e das referências bibliográficas. O tamanho da gentileza com que se prontificaram para ajudar-me só se compara com a capacidade intelectual que revelam em seus próprios trabalhos acadêmicos.

À Professora Dr. ${ }^{a}$ Debora Diniz, pela disponibilidade praticamente imediata para tirar dúvidas e para discutir meu trabalho.

Aos professores e às professoras do Programa de Pós-Graduação em Direito da Universidade de Brasília por todas as contribuições relevantes à minha formação. Em especial, agradeço aos professores Alexandre Araújo Costa, Alexandre Veronese, Argemiro Cardoso 
Moreira Martins, Christiana Soares de Freitas, Cristiano Paixão, José Otávio Nogueira Guimarães e Juliano Zaiden Benvindo, pelas disciplinas e pelas oportunidades de interlocução que representaram momentos de aprendizado intenso.

À Secretaria do Programa de Pós-Graduação em Direito da Universidade de Brasília, pela ajuda com os procedimentos de matrícula, de agendamento da defesa, etc. Agradeço especialmente à Euzilene Morais, pela atenção e pela cordialidade que sempre dispensou a mim quando precisei de seu auxílio.

Ao escritório Humberto Theodoro Júnior Sociedade de Advogados, nas pessoas de seus sócios patrimoniais Humberto Theodoro Júnior, Adriana Mandim Theodoro de Mello, Ana Vitória Mandim Theodoro, Humberto Theodoro Neto e Juliana Cordeiro de Faria, pelo incentivo à formação acadêmica continuada. À Lívia Gonçalves Pinho Piana de Faria, agradeço por ter me desincumbido de algumas atividades para que eu pudesse me concentrar na redação deste trabalho, bem como pela disponibilidade para substituir-me na filial do escritório em Brasília caso isso se fizesse necessário.

À Vanessa Elisa Jacob Anzolin, pela amizade e por compartilhar sua própria experiência durante seu mestrado.

A meus pais, Marcos e Erany, por tudo. 
"O ponto cego, o outro pode ver."

Marcelo Neves 


\section{RESUMO}

O objeto deste trabalho são as interações entre o direito islâmico e outras ordens jurídicas existentes na sociedade mundial contemporânea no enfrentamento de problemas constitucionais relacionados ao direito à liberdade religiosa. O direito islâmico é uma ordem jurídica de matriz religiosa que se desenvolveu nos primeiros séculos do Islã por meio da ijtihad, o processo por meio do qual os juristas mulçumanos extraiam regras a partir das fontes ou raízes do direito, que são o Corão, a sunna do profeta Maomé, o ijmā (consenso) e o qiyās (analogia). A história constitucional dos países em que a sharī'a aplica-se em alguma medida pode ser dividida em cinco fases para fins analíticos. A liberdade religiosa é prevista nos textos constitucionais; porém, restrições infraconstitucionais reduzem sua eficácia. Na solução de casos relativos a esse problema constitucional, há exemplos de conversação constitucional e de recusa ao envolvimento. A tendência de a modernização produzir anomia e a incapacidade do direito islâmico clássico de atender às exigências funcionais da sociedade mundial somam-se à discussão dos casos para mostrar que o transconstitucionalismo é um modelo promissor para o desenvolvimento de institutos que possam levar a uma relação construtiva de aprendizado. $\mathrm{O}$ transconstitucionalismo encontra limites na falta de disposição do direito islâmico para suportar comportamentos diferentes daqueles que ele projeta e na desconfiança de outras ordens jurídicas em relação à sharī'a.

Palavras-chave: Teoria constitucional; Transconstitucionalismo; Direito Islâmico, Liberdade Religiosa. 


\begin{abstract}
The subject of this dissertation are the interactions between Islamic law and other legal orders that exist in contemporary world society while dealing with constitutional problems concerning the right to freedom of religion. Islamic law is a legal order of religious basis which developed during the first centuries of Islam through ijtihad, the process by which Muslim jurists inferred rules from the sources or roots of law, which are the Quran, the sunna of the prophet Mohamed, the $i j m \bar{a}$ (consensus) and the qiyass (analogy). The constitutional history of the countries in

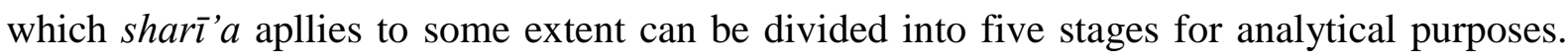
Constitutional texts provide for religious freedom; however, legal restrictions diminish its efficacy. In solving cases relating to this constitutional issue, there are examples of constitutional dialogue as well as refusal to engage. The tendency of modernization to cause anomy and the incapacity of Islamic law to fulfill functional demands of world society add to the evaluation of the cases to show that transconstitutionalism is a promising model for development of institutes that can lead to a constructive relation of learning. Transconstitutionalism is limited by the lack of willingness by Islamic law to tolerate behaviors different from those it had projected and by the distrust of other legal orders relative to sharì'a.
\end{abstract}

Key words: Constitutional Theory; Transconstitutionalism; Islamic Law; Freedom of Religion. 


\section{SUMÁRIO}

INTRODUÇÃ

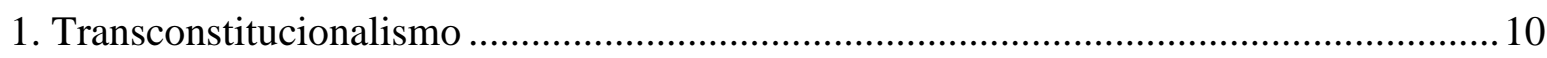

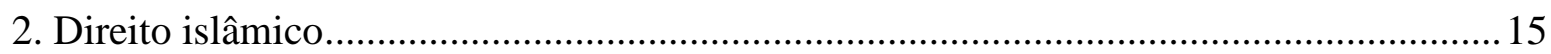

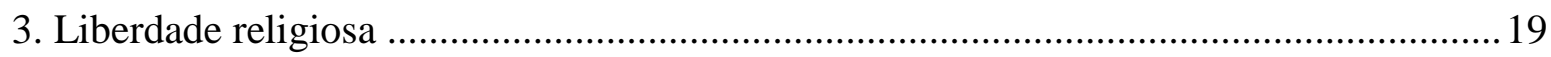

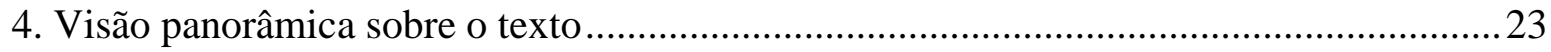

1. DIREITO E CONSTITUIÇÃO NOS PAÍSES DO MUNDO ISLÂMICO.........................25

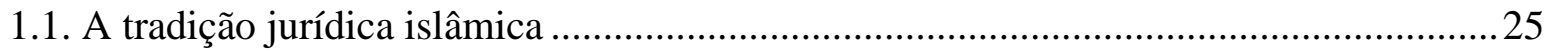

1.2. A evolução constitucional dos países do mundo islâmico........................................... 46

1.3. Direito islâmico e liberdade religiosa: os contornos de um problema constitucional ...52

2. INTERAÇÕES ENTRE O DIREITO ISLÂMICO E OUTRAS ORDENS JURÍDICAS ...57

2.1. Livre exercício da religião: Zaheeruddin et al. v. State, o caso dos Ahmadis (Paquistão)

2.2. Pluralismo religioso: Mahmud Sami Muhammad 'Ali Wasil v. o Ministro da Educação (Egito)

2.3. Democracia e direito: Refah Partisi et al. v. Turquia (Corte Europeia de Direitos Humanos) 75

2.4. Pluralismo jurídico: os British Sharī'a Councils e o direito islâmico na jurisprudência

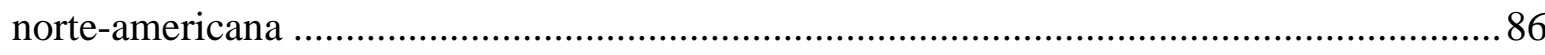

3. TRANSCONSTITUCIONALISMO E DIREITO ISLÂMICO ....................................... 94

3.1. Resistência e disposição ao envolvimento no aprendizado entre ordens jurídicas distintas

3.2. A modernidade nos países do mundo islâmico e a proposta de um constitucionalismo especificamente islâmico 103

3.3. A construção contínua de programas culturais e as perspectivas a partir da chamada "Primavera Árabe". 108

CONCLUSÃO 114

REFERÊNCIAS BIBLIOGRÁFICAS 116 


\section{INTRODUÇÃO}

O objeto deste trabalho são as interações entre o direito islâmico e outras ordens jurídicas existentes na sociedade mundial contemporânea no enfrentamento de problemas constitucionais relacionados ao direito à liberdade religiosa, a fim de avaliar em que medida elas são representativas de uma abertura normativa ao aprendizado recíproco ou, ao contrário, de um bloqueio destrutivo. Assumindo esse ponto de partida, pretende-se também discutir em que medida o modelo do transconstitucionalismo oferece possibilidades de realização do projeto do constitucionalismo moderno nos países do mundo islâmico.

Com o intuito de lançar bases adequadas ao desenvolvimento do texto e de prevenir mal-entendidos, faz-se necessário, de início, justificar as escolhas teóricas, identificar o recorte temático, bem como indicar os limites da abordagem a ser adotada, os quais apontam caminhos possíveis para o aprofundamento da pesquisa.

\section{Transconstitucionalismo}

Neste trabalho, conforme adiantado, pretende-se avaliar a interação entre ordens jurídicas distintas. Nesse sentido, faz-se necessária a adoção de um modelo teórico capaz de explicar por que essas interações acontecem e de que modo elas podem contribuir para a solução de problemas constitucionais, que são, precipuamente, aqueles relacionados a direitos fundamentais e à limitação ou ao controle do poder.

Tornou-se lugar comum falar em "crise do Estado" para definir as dificuldades que os Estados nacionais contemporâneos têm para disciplinar determinados temas e para fazer cumprir suas decisões (CASSESE, 2010). Diversos fatores contribuem para isso, destacandose a globalização econômica (o que inclui a existência das sociedades empresárias multinacionais), bem como a exacerbação de problemas que transpõem fronteiras, a exemplo daqueles atinentes à concorrência internacional, à necessidade de preservação do ambiente e das condições de sobrevivência humana, à unificação das regras esportivas, entre outros.

Além disso, a expansão do direito internacional público a partir do final da Segunda Guerra Mundial, o aumento vertiginoso da quantidade de tratados e de convenções internacionais, o surgimento de organizações supranacionais (tais como a Comunidade Econômica Europeia, a Organização dos Estados Americanos, o MERCOSUL, a Liga dos Estados Árabes, a Organização para Cooperação Islâmica), assim como de organizações transnacionais como a Organização Mundial do Comércio e a Organização Internacional do 
Trabalho; todos esses fatores ampliaram os loci de criação e de concretização do direito e fizeram com que as expectativas normativas em torno das questões jurídicas, inclusive de natureza constitucional, passassem a ser formadas a partir de uma pluralidade de ordens jurídicas e de suas respectivas instituições.

Os mecanismos usuais de incorporação do direito internacional público ao direito doméstico - assinatura, ratificação, promulgação e publicação de tratados e de convenções não se mostram suficientes para explicar a relevância que ordens jurídicas internacionais, supranacionais, transnacionais, estrangeiras ou locais têm adquirido crescentemente para a solução de casos a serem resolvidos por órgãos vinculados a apenas uma dessas ordens. Tampouco as regras de competência e os instrumentos do direito internacional privado, como a carta rogatória e a homologação de sentenças estrangeiras, têm se mostrado suficientes para dar uma resposta a esses desafios. Assim, tanto juízes nacionais quanto juízes internacionais têm aplicado o direito doméstico, o direito internacional ou uma mistura deles com outras ordens jurídicas para resolver casos jurídicos (SLAUGHTER, 2003, p. 192), sem, contudo, estarem necessariamente vinculados formalmente a essas ordens, mas baseando-se em sua “autoridade persuasiva" (GLENN, 1987, passim).

Nesse sentido, tornou-se comum a referência a precedentes da Corte Europeia de Direitos Humanos ou da Suprema Corte dos Estados Unidos nas decisões judiciais proferidas no Brasil ou na África do Sul, para citar apenas dois exemplos. Por óbvio, os precedentes norteamericanos não vinculam o poder judiciário brasileiro, tampouco o direito europeu pode ser considerado cogente para os países que não integram a Convenção Europeia de Direitos Humanos. Logo, esse fenômeno não pode ser explicado por meio da teoria do ordenamento jurídico padrão, cuja matriz positivista sustenta que "A identificação das normas jurídicas é uma questão formal. A origem das normas (não seu conteúdo) é o que determina sua juridicidade" (REGLA, 2007, p. 672, tradução livre). Atualmente, a estrutura das normas jurídicas não parece se esgotar nos programas previstos nos sistemas jurídicos estatais, isto é, nas constituições nacionais, nos códigos, nas leis e nos regulamentos administrativos.

Nesse contexto, tentativas de explicação doutrinária para essas mudanças começaram a surgir recentemente. Ann-Marie Slaughter utiliza a expressão "globalização judicial" para descrever "um processo muito mais diverso e bagunçado de interações judiciais entre, acima e abaixo de fronteiras, trocas de ideias e cooperação envolvendo direito tanto nacional quanto internacional" (SLAUGHTER, 2000, p. 1104, tradução livre). Essa autora, ao mesmo tempo em que reconhece a intensificação do uso de precedentes estrangeiros ou internacionais para a solução de casos constitucionais, rejeita a ideia de que esteja surgindo um 
“sistema jurídico global”, em razão da falta de consistência entre as ordens jurídicas envolvidas. Em vez disso, sustenta a existência de uma "comunidade global de cortes", caracterizada pelo sentimento de pertencimento dos juízes a um empreendimento comum de solução de problemas que ultrapassam as fronteiras nacionais (SLAUGHTER, 2003, p. 193). Além disso, profetiza o surgimento de uma "doutrina de 'comitas judicial"” (SLAUGHTER, 2003, p. 194, tradução livre), que haverá de definir os princípios orientadores do diálogo entre as cortes.

Entre as tentativas de construção de uma teoria das interações entre ordens jurídicas diversas para a solução de problemas constitucionais, o modelo do transconstitucionalismo, proposto por Marcelo Neves (2009), oferece bases adequadas para a abordagem do problema de pesquisa a que este trabalho pretende atender. A tese mantém-se na tradição do constitucionalismo moderno, afastando-se das perspectivas que apontam para a adoção de uma constituição mundial, tidas como conducentes a uma desdiferenciação entre política e direito, ao mesmo tempo em que não reivindica um retorno a práticas constitucionais provincianas. Ela atende aos anseios por uma explicação teórica sobre a relevância de ordens jurídicas diversas para outras em que se coloque determinado problema constitucional, partindo de alguns pressupostos da teoria sistêmica, de conceitos da filosofia da linguagem e de exemplos concretos incontáveis, para descrever os entrelaçamentos entre as ordens jurídicas da sociedade mundial. No transconstitucionalismo, diz o autor, "as ordens se inter-relacionam no plano reflexivo de suas estruturas normativas que são autovinculantes e dispõem de primazia. Tratase de uma 'conversação constitucional'” (NEVES, 2009, p. 118).

Esse modelo não se restringe à perspectiva de um observador externo das interações entre ordens jurídicas diferentes, como também contém os elementos básicos para o desenvolvimento de uma dogmática do transconstitucionalismo que possa ser utilizada para a solução de problemas constitucionais relevantes a mais de uma delas. Em especial, propõe a construção de "pontes de transição" que propiciem vínculos estáveis de abertura normativa, a fim de que se possam estabelecer relações de aprendizado recíproco entre ego e alter (isto é, entre a ordem jurídica competente para responder ao caso específico e aquela com a qual ela estabelece um diálogo transconstitucional).

Para entender o motivo por que Marcelo Neves compreende o transconstitucionalismo como uma exigência funcional, faz-se necessário compreender o uso que ele faz de categorias da teoria dos sistemas, sobretudo do conceito de "sociedade mundial" (LUHMANN, 2006). De acordo com Niklas Luhmann, as condições modernas impedem que se possa caracterizar o sistema social abarcante como um conjunto de sociedades regionais, porque ele se diferencia funcionalmente em sistemas parciais, que operam independentemente 
de limites espaciais (LUHMANN, 2006, p. 564-565). Tendo em conta que tanto o sistema social abarcante quanto os sistemas parciais são constituídos por comunicações, segundo seus respectivos códigos binários, “A sociedade mundial significa, em princípio, que o horizonte das comunicações ultrapassa as fronteiras territoriais do Estado [...] Nesse sentido, a sociedade deixa de ser vinculada diretamente ao ente estatal" (NEVES, 2012, p. 217).

Nesse quadro de referências, o direito é um sistema funcional da sociedade mundial. Uma pluralidade de ordens jurídicas diferentes existem, "subordinadas ao mesmo código binário, isto é, lícito/ilícito, mas com diversos programas e critérios" (NEVES, 2009, p. 116), porque, além da diferenciação funcional (que é a forma de diferenciação primária), há também uma diferenciação segmentária no interior do sistema jurídico, que inclui não só as "ordens jurídicas estatais com âmbitos territoriais de validade delimitados [...], mas também a diferenciação funcional de ordens jurídicas transnacionais, desvinculadas, por sua transterritorialidade, do direito estatal" (NEVES, 2009, p. 116). Isso implica que o sistema jurídico da sociedade mundial é multicêntrico, “de tal maneira que, na perspectiva do centro (juízes e tribunais) de uma ordem jurídica, o centro de uma outra ordem jurídica constitui uma periferia" (NEVES, 2009, p. 117).

Outra vantagem dessa perspectiva consiste no fato de que o transconstitucionalismo admite o envolvimento ou a tentativa de diálogo com ordens jurídicas que não são comprometidas com a constituição no sentido moderno, como é o caso dos textos constitucionais na maior parte dos países do mundo árabo-islâmico (BROWN, 2002, p. 91 e ss.), ainda que reconheça o desafio enorme que isso implica (NEVES, 2009, p. 184 e 276). A questão da existência de instituições constitucionais no sentido moderno no contexto áraboislâmico será abordada oportunamente. Por ora, importa mostrar a compatibilidade do modelo teórico eleito com o objeto do estudo.

Igualmente, faz-se necessário esclarecer que o modelo do transconstitucionalismo não será avaliado criticamente, mas assumido como pressuposto para o enfrentamento do tema principal. Com isso, não se pretende afirmar que ele é perfeito, mas que é útil aos propósitos deste trabalho. Apesar disso, cabe tecer considerações sucintas quanto a duas objeções distintas à tese do transconstitucionalismo, visto que poderiam ser levantadas em relação à delimitação temática e às conclusões deste estudo. 
Em primeiro lugar, vale a pena mencionar a crítica de Maurizio Oliviero, ${ }^{1}$ para quem a tese enfatiza exageradamente o papel dos tribunais. O transconstitucionalismo não ignora que influências recíprocas importantes podem surgir no procedimento legislativo (por exemplo, por meio da discussão sobre propostas legislativas semelhantes àquelas que países estrangeiros adotaram para disciplinar determinado tema); tampouco nas políticas públicas desenhadas pelo poder executivo. ${ }^{2}$ No entanto, parte do princípio de que estão na periferia do sistema jurídico, porque não têm a obrigação de decidir (LUHMANN, 2005, p. 383). Antes, "a periferia serve de zona de contato com outros sistemas funcionais da sociedade" (LUHMANN, 2005, p. 383, tradução livre) - o contrato, como zona de contato entre direito e economia; a legislação, como zona de contato entre direito e política. Em contrapartida, a organização da jurisdição é o centro do sistema do direito, porque, em razão da obrigação de decidir, serve ao fechamento operacional do direito para cumprir a função específica de estabilização contrafática de expectativas normativas de conduta (LUHMANN, 2005, p. 385). Essa centralidade justifica a ênfase da tese do transconstitucionalismo nos tribunais como loci privilegiado do diálogo transconstitucional.

Em segundo lugar, convém considerar a crítica de Argemiro Martins, ${ }^{3}$ de acordo com a qual os problemas exemplificativos do transconstitucionalismo entre ordens jurídicas estatais dispensariam o diálogo transnacional. Em alguns casos, deve-se concordar com essa crítica, no sentido de que o julgamento poderia ter se dado com base nos programas e critérios definidos somente pela ordem jurídica estatal, sem referência a precedentes estrangeiros. Entretanto, quando determinado tribunal incorpora materiais normativos advindos de ordens jurídicas em seu entorno à ratio decidendi da decisão, isto é, ao fundamento determinante para o resultado proclamado, enlaça essa decisão à jurisprudência internacional, supranacional, transnacional, estrangeira ou local. Esse entrelaçamento é o aspecto definidor do transconstitucionalismo, de modo que não se podem excluir as hipóteses que envolvem ordens

\footnotetext{
${ }^{1}$ Referência às aulas ministradas na disciplina "Do constitucionalismo ao transconstitucionalismo: o problema da decisão judicial", ofertada pelo Programa de Pós-Graduação em Direito da Universidade de Brasília no primeiro semestre letivo de 2014.

2 "Entretanto, nem todo entrelaçamento de ordens jurídicas ocorre entre tribunais. Muitas vezes, há a incorporação de normas de outra ordem, sem intermediação de diálogos entre tribunais. Uma reinterpretação da própria ordem a que está vinculado um tribunal pode ocorrer em face da incorporação de sentidos normativos extraídos de outras ordens jurídicas. Além disso, em outros níveis do sistema jurídico, há aprendizados e intercâmbios permanentes, como ocorre na relação informal entre legislativo, governos e administrações de diversos países. Sem dúvida, porém, a forma mais relevante de transversalidade entre ordens jurídicas é a que perpassa os juízes e tribunais, seja interjudicialmente ou não" (NEVES, 2009, p. 118).

3 Igualmente, trata-se de uma referência às aulas ministradas na disciplina "Do constitucionalismo ao transconstitucionalismo: o problema da decisão judicial", ofertada pelo Programa de Pós-Graduação em Direito da Universidade de Brasília no primeiro semestre letivo de 2014.
} 
jurídicas estatais. ${ }^{4}$ Além disso, convém ter em linha de conta o fato de que "direitos humanos pretendem valer para o sistema jurídico mundial de níveis múltiplos, ou seja, para qualquer ordem jurídica existente na sociedade mundial” (NEVES, 2009, p. 253). Em razão disso, mesmo que um tribunal fundamente sua decisão baseando-se exclusivamente em materiais normativos da própria ordem jurídica estatal, o problema que ele enfrenta pode permanecer relevante para outras ordens jurídicas. O risco do fechamento normativo é a fragmentação destrutiva do sistema jurídico da sociedade mundial abarcante.

Essa introdução sucinta ao transconstitucionalismo não se pretende uma exposição exaustiva nem uma avaliação crítica da teoria. Ela visa apenas a justificar a escolha desse modelo para a elaboração do trabalho. Outros aspectos aparecerão ao longo do texto, quando necessários à análise do tema principal.

\section{Direito islâmico}

Entre todas as ordens jurídicas que compõem o sistema jurídico da sociedade mundial, o direito islâmico e aquelas que interagem com ele são as que interessam a este trabalho. A fim de delimitar adequadamente o objeto do estudo e antecipar seus limites, alguns esclarecimentos iniciais revelam-se indispensáveis.

Quando se refere ao direito islâmico ou à sharī' $a,{ }^{5}$ o texto aponta para a tradição jurídica religiosa a que estão vinculados os adeptos do Islã. Segundo autores do direito

\footnotetext{
${ }^{4}$ Sob a ótica da teoria retórica da argumentação jurídica de Neil MacCormick, "pode-se dar uma definição clara e satisfatória de ratio decidendi, nos seguintes termos: 'Uma ratio decidendi é uma justificação formal explícita ou implicitamente formulada por um juiz, e suficiente para decidir uma questão jurídica suscitada pelos argumentos das partes, questão sobre a qual uma resolução era necessária para a justificação da decisão no caso'. Argumentos sobre princípio ou argumentos avaliando outros casos dotados de autoridade ou ainda as consequências da solução escolhida e de suas rivais pertencerão à classe das obiter dicta. Isso é assim, mesmo que tais argumentos sejam necessários para justificar a solução dada, e mesmo que apenas os argumentos efetivamente aduzidos possam justificar tal solução" (MACCORMICK, 2008, p. 203, negrito acrescido). Embora Marcelo Neves adote uma definição diferente, sustentando que a distinção entre ratio decidendi e obiter dictum corresponde a uma gradação "entre razões fortes e diretas e razões mais frágeis e indiretas" (NEVES, 2009, p. 167-168, nota 132), ela não se mostra suficientemente precisa para afastar completamente o risco de contradição interna quanto ao uso de precedentes de tribunais de outros países com força de convencimento ser efetivamente uma espécie de transconstitucionalismo. Este trabalho, conquanto reconheça esse problema, não pretende enfrentá-lo, mantendose fiel ao marco teórico eleito para o estudo proposto. A questão não deve repercutir de modo mais agudo na discussão do tema principal, porque outros modelos relacionados à interação entre ordens jurídicas distintas, como, por exemplo, a "globalização do direito constitucional doméstico" (TUSHNET, 2008, p. 2 e ss., tradução livre), a "comunidade global de cortes" (SLAUGHTER, 2003) ou o "modelo de engajamento" (JACKSON, 2005, p. 114 e ss.), mostram a relevância do diálogo entre as cortes ou, em outras palavras, da "fertilização cruzada constitucional" (SLAUGHTER, 2003, p. 194 e ss.), para as práticas constitucionais contemporâneas. Assim, ainda que não se aderisse completamente ao modelo do transconstitucionalismo, a interação entre ordens jurídicas estatais permaneceria pertinente ao objeto de pesquisa.

${ }^{5} \mathrm{Na}$ transliteração de termos em árabe para o alfabeto romano, utilizar-se-á o mesmo padrão adotado pelo professor Maurizio Oliviero em seus trabalhos acadêmicos referenciados ao final. Sobre esse padrão, cf. OLIVIERO (2003,
} 
comparado, não se pode compreender o Islã sem conhecer o direito islâmico. De acordo com René David, “O islã é, na sua essência, [...] uma religião da Lei” (DAVID, 1993, p. 410). Semelhantemente, Joseph Schacht afirma que o "direito islâmico é a epítome do pensamento islâmico, a manifestação mais típica do modo de vida islâmico, o núcleo do próprio Islã" (SCHACHT, 1964, p. 1, tradução livre). ${ }^{6}$

Esse aspecto justificaria por si só a escolha dessa ordem jurídica como foco da investigação. Somando-se a ele, cabe mencionar que a população muçulmana - em maior ou menor medida influenciada pelo direito islâmico - correspondia, em 2010, a 22,5\% da população mundial. ${ }^{7}$ Apesar disso, os estudos publicados no Brasil sobre o direito islâmico são poucos e superficiais, ${ }^{8}$ de modo que este trabalho tem o condão de abrir possibilidades novas de pesquisa acadêmica no campo do direito. Embora a intenção não seja fazer uma descrição completa sobre o direito islâmico, a compreensão dos casos a serem avaliados e das interações entre a tradição jurídica islâmica e outras ordens jurídicas depende de uma explicação sobre os elementos caracterizadores da ordem jurídica muçulmana principais. Com essa finalidade,

p. 1-2, tradução livre): “Um dos maiores problemas da comparação consiste na tradução das expressões linguísticas que exprimem os conceitos jurídicos. No caso específico, além disso, a utilização de uma língua diversa (aquela árabe), caracterizada por variações profundas (clássicas e contemporâneas) e em qualquer caso adaptada para a escrita de línguas de tronco diverso (persa, turco, etc.), constitui um empreendimento ainda mais árduo. Todavia, sob um ponto de vista meramente metodológico e com os limites que seguramente se seguem a ele, adotaram-se algumas escolhas seja no que diz respeito às transcrições, seja no que diz respeito às correspondências conceituais. Relativamente ao primeiro problema, exatamente para assinalar que se tratam de realidades e de instituições 'outras' em relação àquelas comumente definidas como 'ocidentais', escolheu-se conservar ao máximo os termos originais árabe-muçulmanos. O termo $q \bar{a} d \bar{l}$, por exemplo, é empregado na transcrição mais fiel possível e preferido à forma 'cadì', assim como à opção excessivamente forçada de "juiz" (o qādī não é um juiz ocidental, nem de tempos passados, nem de hoje). Ademais, mesmo indicando o quanto possível os plurais, as palavras transcritas foram deixadas quase sempre no singular, ainda que usadas em um contexto italiano plural. No que diz respeito, em contrapartida, ao problema da correspondência entre conceitos jurídicos, preferiu-se renunciar à tradução quando a expressão linguística assume uma conotação conceitual estranha ou não prevalente no interior das categorias gerais do constitucionalismo ocidental. De todo modo, a tradução operou-se unicamente a fim de tornar mais compreensível, na economia do estudo, algumas afirmações; entretanto, nesses casos reportou-se entre parêntesis à transcrição original e, quando necessário, em nota de rodapé uma explicação conceitual sobre o uso do termo. Na consciência dos limites que esse método pode ter, porém para a finalidade de uma primeira introdução ao estudo do constitucionalismo árabe, essa escolha pareceu a única praticável."

Uma exceção a esse padrão será a substituição do caractere “ $g$ ” pela letra “ $j ”$, o que aproximará as transliterações de alguns termos àquelas constantes das referências em língua inglesa.

${ }^{6}$ Mohammad Hashim Kamali considera essa afirmação de Joseph Schacht exagerada, atribuindo-a a uma tendência “to overlegalize" o Islã (KAMALI, 2008, p. 1).

7 The Association of Religion Data Archives. World Religions. Disponível em: http://www.thearda.com/q12010/QuickList_125.asp. Acesso em: 01 fev. 2016.

${ }^{8}$ Por exemplo, a pesquisa identificou apenas uma tese de doutorado no campo do direito que trata especificamente sobre a ordem jurídica islâmica (EL SAWY, 2002), além de alguns artigos esparsos. Quanto ao mais, a maior parte das publicações localizam-se mais precisamente no campo da história, das relações internacionais ou da antropologia social. 
então, apresentar-se-ão pontos relevantes da dogmática do direito islâmico, ${ }^{9}$ a fim de propiciar ao leitor ou à leitora informações necessárias ao entendimento do texto.

No entanto, cumpre chamar a atenção desde logo para a diferença entre o direito islâmico clássico e as ordens jurídicas estatais dos países do mundo islâmico. O direito islâmico é uma ordem jurídica religiosa, cujas fontes mais importantes são consideradas sagradas e, por conseguinte, insuscetíveis de alteração por meio do processo democrático. ${ }^{10} \mathrm{Em}$ contrapartida, as ordens jurídicas estatais contêm programas próprios (constituições, leis, regulamentos administrativos), distintos daqueles reconhecidos pela tradição. Embora sejam diferentes, essas ordens jurídicas estão vinculadas indissociavelmente, seja porque os textos constitucionais incorporam a sharī'a ao ordenamento estatal por meio de dispositivos que instituem o Islã como religião oficial do Estado ou que declaram a sharī'a como fonte do direito doméstico (OLIVIERO, 2014, p. 619), seja porque alguns ramos da ordem estatal, em especial o direito de família e o direito das sucessões, são influenciados fortemente pela tradição jurídica muçulmana (DAVID, 1993, p. 427 e ss.). A coexistência e a tensão entre essas ordens serão objeto específico de análise em momento oportuno.

Além disso, deve-se alertar para a existência de diferenças importantes entre os países que compõem o mundo islâmico, visto que as práticas constitucionais e o fenômeno jurídico de modo geral não se apresentam uniformemente em todos eles. Diferenças históricas, culturais, étnicas, econômicas repercutem distintamente em cada um desses países. Exemplificativamente, no que tange ao papel da religião no Estado, tem-se, num extremo, o Irã, que vive atualmente sob um regime teocrático, e a Arábia Saudita, que adota oficialmente uma versão fundamentalista do direito islâmico (wahabismo); e, noutro, a Turquia, onde prevalece uma laicidade comparativamente assertiva. ${ }^{11}$ Mesmo assim, o texto conterá algumas generalizações, que se justificam por três motivos. Em primeiro lugar, porque os países do mundo islâmico "foram, a seu tempo, parte mais ou menos importante dos primeiros impérios fundados em nome do Islã" (OLIVIERO, 2014, p. 593, tradução livre) e mantiveram certa

\footnotetext{
${ }^{9}$ Deve-se esclarecer que "dogmática", aqui, não faz referência a crenças religiosas indiscutíveis, tampouco às regras específicas do direito islâmico. Pretende apenas apontar para uma explicação da ordem jurídica islâmica que enfatize a descrição de sua história, de suas características principais e de seus métodos, de acordo com a doutrina especializada, em especial com os autores do direito islâmico com publicações em línguas acessíveis, sem questionar profundamente os pressupostos nem a retidão de suas asserções. Trata-se, portanto, de cumprir um dever de explicação, em oposição ao dever de fundamentação, ou, em outras palavras, de limitar a reflexividade na abordagem do tema. Sobre a dogmática jurídica, cf. ROESLER (2013, p. 49-56).

${ }^{10}$ Há, contudo, tentativas de ressignificação do conceito especificamente islâmico de "shura", que, em tradução literal, significa "consulta", com vistas à modificação desse aspecto.

${ }^{11}$ Quanto à Turquia, essa afirmação vale para o secularismo da república fundada após a Primeira Guerra Mundial sob a liderança de Mustafa Kemal Atatürk e exclui tentativas mais recentes de atribuir um papel mais relevante à religião na ordem jurídica do país.
} 
unidade, "que não era efetiva, mas exprimia sua vontade de reconhecer-se em algo mais amplo, de natureza supranacional, como se diria hoje" (OLIVIERO, 2014, p. 593, tradução livre). O direito islâmico, em razão de sua matriz religiosa, não se circunscreve a um âmbito territorial determinado de validade, mas pode atingir, em escalas variadas, todas as pessoas muçulmanas, onde quer que se encontrem. Tem, portanto, pretensão de validade transnacional. Em segundo, mesmo que a generalização implique a perda de detalhes, ela permite uma aproximação mais veloz a um grupo de ordens jurídicas que compartilha determinadas características e facilita o estudo do direito estrangeiro, assim como a identificação de seus valores fundamentais objetivo a que as classificações no campo do direito comparado servem (HERTEL, 2009, p. 171; OLIVIERO, s.d.-b, p. 3 do documento eletrônico cedido pelo autor). Tendo em conta a falta de estudos sobre direito islâmico no Brasil, essa aproximação mais abrangente é recomendável, mesmo que em sacrifício de algumas peculiaridades. Por fim, há a esperança de que algumas generalizações ajudem a explicitar, no futuro, exceções que contribuam para aperfeiçoá-las, por meio do aprofundamento da pesquisa e da crítica. Independentemente disso, sempre que necessário, os casos excepcionais serão particularizados, evitando-se a reprodução acrítica de representações sociais preconceituosas sobre o Islã ou sobre as pessoas muçulmanas, assim como os riscos do essencialismo. ${ }^{12}$

Outro aspecto que justifica a relevância da ordem jurídica islâmica e de sua relação com outros ordenamentos como objeto de investigação acadêmica consiste nos movimentos migratórios da população muçulmana, os quais se acentuaram recentemente em função da situação grave de guerra civil na Síria. O incremento das populações muçulmanas nos países ocidentais torna urgente a discussão sobre formas de diálogo e de abertura normativa, sobretudo, porque, como já mencionado, o direito islâmico está no centro das convicções religiosas muçulmanas. De fato, os processos de integração dos adeptos do Islã nos países ocidentais, sobretudo na Europa, podem representar um dos modelos mais relevantes e, ao mesmo tempo, mais desafiadores de diálogo entre comunidades que têm representações

\footnotetext{
12 "Existe uma visão comum de que a sharī'a é fixa e claramente distinguível de suas fontes sagradas. Para ideólogos muçulmanos, essa fixidez e clareza são funções de sua origem divina. Para muitos observadores ocidentais elas são funções da rigidez da 'sociedade muçulmana', totalmente outra em relação ao 'Ocidente', com a religião como sua essência [...]. Essa visão [de que o Islã é uma civilização total, não só uma religião, como também um sistema político e social] é sustentada por alguns comentadores ocidentais, alinhando-se à posição do 'choque de civilizações', e por islamitas, insistentes quanto à totalidade e à indivisibilidade do Islã. Existe um tipo de simbiose ideológica entre os dois. 'Sociedade muçulmana' sob essa perspectiva não é sujeitável a uma análise em termos de economia, política ou sociologia, mas tem a religião como sua essência que a move e que determina seus processos. A lei sagrada é a parte principal dessa essência. Não é apenas um direito, mas um 'discurso total', determinando família, moralidade, ritual e política." (ZUBAIDA, 2003, p. 1 e 3, tradução livre). Essa perspectiva "essencialista" é redutora, porque desconsidera tanto a diversidade das comunidades islâmicas ao longo da história, como também o papel da interpretação.
} 
diferentes sobre o direito e sobre o papel da religião na construção de expectativas normativas de conduta, a ponto de falar-se em "um euro-Islã, que deriva do conceito do Islã como realidade aberta politicamente, na medida em que interpretável de modos diversos" (OLIVIERO, s.d.-a, p. 16 do documento eletrônico cedido pelo autor, tradução livre).

A avaliação das práticas jurídicas nos países do mundo islâmico serve também para testar os limites do transconstitucionalismo como modelo de abertura normativa para o aprendizado recíproco entre ordens jurídicas, porque esses países não parecem comprometidos, de modo geral, com o ideal regulativo da constituição em sentido moderno, dado que os textos constitucionais que a maior parte deles adotou têm se prestado, historicamente, a organizar o exercício dos poderes estatais sem necessariamente limitá-los (BROWN, 2002, p. 91 e ss.). Assim, o estudo proposto tem importância teórica, podendo contribuir para o refinamento da teoria constitucional contemporânea.

Essas considerações iniciais visam a justificar a escolha do objeto de pesquisa e a indicar o âmbito delimitação temática do trabalho. A título de esclarecimento, importa mencionar, por fim, que a ausência de referências bibliográficas em árabe ou em outras línguas utilizadas majoritariamente nos países do mundo islâmico é suprida, ${ }^{13}$ na medida do possível, por intermédio dos autores muçulmanos com publicações em línguas mais acessíveis, sobretudo o inglês, além das traduções disponíveis.

\section{Liberdade religiosa}

Após a escolha do direito islâmico como ordem jurídica cujas interações seriam objeto de avaliação, a preocupação com a viabilidade do estudo tornou necessária a seleção de um problema constitucional específico, recortando o tema de modo compatível com a amplitude e com o grau de profundidade que se pretende conferir a este trabalho.

Nesse sentido, na fase de elaboração do projeto de pesquisa e a partir de uma exploração superficial dos materiais disponíveis, observou-se que casos judiciais relacionados ao direito à liberdade religiosa têm provocado o contato entre a sharī'a e ordens jurídicas distintas mais frequentemente do que outros problemas constitucionais. Se essas interações são representativas de um diálogo transconstitucional, será discutido adiante, convindo adiantar

\footnotetext{
${ }^{13}$ As dificuldades de acesso às fontes primárias e de leitura em árabe, assim como a falta de traduções adequadas, são reclamações comuns entre os estudiosos ocidentais do direito islâmico, como mencionam, exemplificativamente, Brown e Lombardi (2006, p. 438), além de Locchi e Oliviero (2015, p. 4 do documento eletrônico cedido pelo autor).
} 
apenas que podem ser exemplificativas de uma abertura normativa ou de uma rejeição ao envolvimento. Por ora, basta deixar claro que a delimitação temática em torno da liberdade religiosa decorre principalmente da impressão inicial de que ela propiciaria uma moldura profícua ao debate sobre o transconstitucionalismo e o direito islâmico.

Naquele momento preliminar de construção do projeto, consultou-se o livro Comparative Constitutionalism: Cases and materials (DORSEN et al., 2010) e os periódicos especializados em língua inglesa disponíveis nas bases de dados da Biblioteca Central dos Estudantes da Universidade de Brasília, a exemplo do International Journal of Middle East Studies, do Yearbook of Islamic and Middle Eastern Law, do Journal of Islamic State Practices in International Law, dentre outros, à busca de casos concretos que pudessem orientar a discussão. Assim, chegou-se ao problema da liberdade religiosa.

A percepção alcançada nessa fase exploratória contraria os resultados iniciais da pesquisa conduzida por Maria Chiara Locchi e por Maurizio Oliviero, docentes da Università degli Studi di Perugia (Itália), sobre a circulação da doutrina estrangeira nas decisões judiciais proferidas pelas cortes constitucionais dos países árabes. Eles apontam para a utilização mais frequente de obras que abordam a repartição de poderes e o funcionamento dos órgãos constitucionais em comparação a outros temas (LOCCHI; OLIVIERO, 2015, p. 14 do documento eletrônico cedido pelo autor), o que sugeriria outra sorte de problema constitucional. Entretanto, vale reparar que o estudo concentra-se no uso de apenas uma das fontes do direito, qual seja, a doutrina, optando por deixar de fora o diálogo entre as cortes ou o uso de precedentes estrangeiros para a solução de casos constitucionais. Mesmo assim, ele ajuda a mostrar que o direito nos países do mundo islâmico não está isolado. No Líbano, por exemplo, "o recurso ao direito comparado adquiriu recentemente um peso relevante; aparece cada vez mais clara a consciência, no contexto globalizado atual, da importância das trocas entre juízes e jurisprudências a fim de promover alguns princípios fundamentais do direito e os direitos do homem" (LOCCHI; OLIVIERO, 2015, p. 11 do documento eletrônico cedido pelo autor, tradução livre).

Não só a liberdade religiosa revela-se útil ao propósito de discutir as interações entre o direito islâmico e ordens jurídicas diversas, como também representa um problema que se apresenta com frequência e com gravidade nos países de população majoritariamente muçulmana. Com efeito, a pesquisa de Brian J. Grim e de Roger Finke demonstra, a partir de dados obtidos por meio dos relatórios sobre liberdade religiosa do Departamento de Estado norte-americano e codificados pela Association of Religion Data Archives, que os padrões de perseguição religiosa são mais elevados em áreas predominantemente muçulmanas, sobretudo 
no Oriente Médio e no Sul da Ásia. Se as violações a esse direito são persistentes e graves, então a discussão acadêmica que as tangencie adquire também relevância prática, como, aliás, normalmente se espera no campo das ciências sociais aplicadas.

Faz-se necessário esclarecer que, a despeito de a seleção do problema constitucional ter se baseado eminentemente na utilidade que possui para a investigação das interações entre o direito islâmico e outras ordens jurídicas, o trabalho não se preocupa com a representatividade estatística dos casos que serão avaliados. Trocando em miúdos, não afirma que as situações retratadas correspondem a um recorte estatisticamente significativo de um conjunto maior de decisões judiciais cujas características básicas reproduziriam fielmente, tampouco investiga a quantidade de vezes em que os tribunais dos países do mundo islâmico fazem referência a precedentes internacionais, supranacionais, transnacionais, estrangeiros ou locais. O enfoque é qualitativo: ao propor a avaliação dessas interações, este estudo quer entender os limites e as possibilidades do transconstitucionalismo em relação à ordem jurídica muçulmana.

Provisoriamente, convém acordar um sentido normativo para "liberdade religiosa", a fim de que se tenha presente o que se quer dizer quando se fala em violações a esse direito. Nesse sentido, o art. 18 do Pacto Internacional sobre os Direitos Civis e Políticos contém o núcleo daquilo a que se pode referir como "liberdade religiosa":

“1. Toda pessoa terá direito a liberdade de pensamento, de consciência e de religião. Esse direito implicará a liberdade de ter ou adotar uma religião ou uma crença de sua escolha e a liberdade de professar sua religião ou crença, individual ou coletivamente, tanto pública como privadamente, por meio do culto, da celebração de ritos, de práticas e do ensino.

2. Ninguém poderá ser submetido a medidas coercitivas que possam restringir sua liberdade de ter ou de adotar uma religião ou crença de sua escolha.

3. A liberdade de manifestar a própria religião ou crença estará sujeita apenas à limitações previstas em lei e que se façam necessárias para proteger a segurança, a ordem, a saúde ou a moral públicas ou os direitos e as liberdades das demais pessoas.

4. Os Estados Partes do presente Pacto comprometem-se a respeitar a liberdade dos países e, quando for o caso, dos tutores legais de assegurar a educação religiosa e moral dos filhos que esteja de acordo com suas próprias conviç̧ões." 14

Vale mencionar que o direito à liberdade religiosa não se restringe a uma proibição ao envolvimento do Estado nas crenças e nas práticas religiosas dos indivíduos, mas, igualmente, na sua falha em proteger grupos que professem determinada fé minoritária ou,

\footnotetext{
${ }^{14}$ BRASIL. Decreto 592, de 6 de julho de 1992. Atos Internacionais. Pacto Internacional sobre Direitos Civis e Políticos. Promulgação. Disponível em: http://www.planalto.gov.br/ccivil 03/decreto/1990-1994/D0592.htm. Acesso em: 10 fev. 2016.
} 
ainda, que não tenham crença de tipo religioso alguma. Essa asserção encontra-se em linha de coerência com o modelo do Estado de Direito pressuposto pela teoria transconstitucional, fundado em uma esfera pública pluralista.

Quanto a esse aspecto, cabe destacar que a religião, na medida em que constituiu um sistema parcial da sociedade abarcante, integra o ambiente dos demais sistemas parciais e que a liberdade religiosa, por sua vez, garante o fechamento operacional do direito e da política em relação a ela. Via de consequência, em um contexto de violação sistemática a esse direito fundamental e humano, corre-se o risco de desdiferenciação, porque as pressões advindas da religião ameaçam sobrepor seu código binário imanente/transcendente aos códigos do direito e da política. Prima facie, isso é o que acontece em uma parte dos países do mundo islâmico, onde as pressões sociais e religiosas pela incorporação da sharī’a às ordens jurídicas estatais ou mesmo a substituição destas por aquela - podem ser explicadas, sob a perspectiva sistêmica, como uma espécie de alopoiese do direito. ${ }^{15}$

Retornar-se-á a essa hipótese posteriormente. Por enquanto, ela serve tanto para aprofundar a justificativa da delimitação temática, como também para mostrar que abordar a liberdade religiosa como um direito individual negativo de proibição à intervenção estatal na esfera de autonomia privada não é suficiente. A religião é repleta de conteúdos que concorrem para a criação do direito. As pressões sociais que provocam incidentes de desrespeito ao direito subjetivo à liberdade religiosa também insistem na imposição estatal de preceitos religiosos. Em razão disso, problemas decorrentes das pretensões sobre o papel da religião no Estado e no direito, traduzidos juridicamente como questões constitucionais atinentes aos dispositivos da laicidade e do secularismo, também devem compor o objeto do estudo.

Feitas essas considerações, mostra-se oportuno adiantar que os textos constitucionais dos países do mundo islâmico, ao mesmo tempo em que incorporam a sharī'a, de uma forma ou de outra, às ordens jurídicas estatais, albergam, ao menos textualmente, a liberdade religiosa, ainda que convivam de vez em quando com legislação infraconstitucional que restringe fortemente o exercício desse direito ou com um déficit de concretização cotidiana. Além disso, autores vinculados à tradição islâmica buscam aproximar-se dos direitos humanos

\footnotetext{
15 Sobre alopoiese, cf. NEVES (2007, p. 142): “O direito enquanto sistema autopoiético é, ao mesmo tempo, normativamente simétrico e cognitivamente assimétrico. Só quando há uma assimetrização externa no plano da orientação normativa é que surge o problema da alopoiese como negação da auto-referência operacional do direito. Derivada etimologicamente do grego állos ('um outro', 'diferente') + poíesis ('produção', 'criação'), a palavra designa a (re)produção do sistema por critérios, programas e códigos do seu ambiente. O respectivo sistema é determinado, então, por injunções diretas do mundo exterior, perdendo em significado a própria diferença entre sistema e ambiente. Por outro lado, bloqueios alopoiéticos do sistema são incompatíveis com a capacidade de reciclagem (abertura cognitiva) e, por conseguinte, com a própria noção de referência ao ambiente como interrupção da interdependência dos componentes sistêmicos."
} 
de liberdade religiosa a partir de pressupostos especificamente muçulmanos. Essas elaborações serão exploradas a seu tempo, visto que estão no cerne das interações ou das possibilidades de diálogo entre o direito islâmico e outras ordens jurídicas no enfrentamento desse problema constitucional.

\section{Visão panorâmica sobre o texto}

No primeiro capítulo, o trabalho apresenta o direito islâmico como ordem jurídica, explicando os aspectos principais que o caracterizam. Em seguida, expõe a evolução constitucional dos países do mundo islâmico de acordo com a reconstrução histórica de Maurizio Oliviero, que a divide em cinco fases: a primeira, marcada pelo expansionismo saudita com base na ideia de recuperação dos valores originais do Islã; a segunda, definida a partir da imposição dos modelos constitucionais ocidentais; a terceira; caracterizada pelo projeto panarabista de Gamal Abd al-Nasser; a quarta, delimitada pela crise do ideal arabista e retorno parcial a nacionalismos locais; e a quinta, determinada pela Revolução Iraniana. Por fim, delineia os contornos principais do problema da liberdade religiosa.

No segundo capítulo, descreve casos em que o direito islâmico tenha entrado em contato com outras ordens jurídicas para solucionar um problema atinente à liberdade religiosa. O primeiro é Zaheeruddin v. State, um caso em que a Suprema Corte do Paquistão julgou a constitucionalidade da proibição ao uso de símbolos religiosos muçulmanos por membros da comunidade Ahmadi com base em precedentes da jurisprudência estadunidense, principalmente. O segundo é Mahmud Sami Muhammad 'Ali Wasil v. o Ministro da Educação, no qual a Suprema Corte Constitucional do Egito avaliou a compatibilidade de um regulamento administrativo com o artigo $2^{\circ}$ da constituição, que prevê a sharī'a como fonte principal da legislação estatal. O terceiro é Refah Partisi et al. v. Turquia, em que a Corte Europeia de Direitos Humanos manteve a decisão da Corte Constitucional turca que dissolveu um partido político que teria se tornado um "centro de atividades contrárias ao secularismo". Finalmente, há a exposição sobre os British Sharī'a Councils, no Reino Unido, e sobre o caso Awad v. Ziriax, dos Estados Unidos, em que se debateu a constitucionalidade à luz do texto constitucional federal de uma proposta de emenda à constituição do estado de Oklahoma que pretendia proibir os juízes dessa jurisdição de considerarem a shari'a em qualquer julgamento.

No terceiro e último capítulo, avaliam-se os casos à luz do transconstitucionalismo como modelo de entrelaçamento de ordens jurídicas, a fim de determinar em que medida eles seriam exemplificativos de uma conversação constitucional ou, ao contrário, de uma recusa ao 
envolvimento. Em seguida, o trabalho contrapõe a tentativa de imposição da modernidade à de construir um constitucionalismo propriamente islâmico, com o objetivo de oferecer um diagnóstico sobre as possibilidades do transconstitucionalismo em relação ao direito islâmico. Por fim, narra os acontecimentos que ficaram conhecidos como "Primavera Árabe" e especula se eles constituiriam um momento de mudança constitucional.

Conclui-se que o limite do transconstitucionalismo para o direito islâmico consiste em sua incapacidade de conceber um comportamento diverso daquele projetado pelo ego quanto à solução de alguns casos relacionados à liberdade religiosa, bem como à falta de procedimentos constitucionais capazes de preservar a esfera pública e de legitimar o resultado procedimental eventual. Em contrapartida, o limite do transconstitucionalismo para as ordens jurídicas ocidentais em relação ao direito islâmico é a desconfiança, que impede a construção de "pontes de transição". Mesmo assim, o transconstitucionalismo oferece um modelo promissor para o inter-relacionamento entre essas ordens jurídicas, na medida em que possibilita a construção gradual de institutos que viabilizem relações de aprendizado recíproco mesmo em ambientes refratários à constituição em sentido moderno. 


\section{DIREITO E CONSTITUIÇÃO NOS PAÍSES DO MUNDO ISLÂMICO}

\subsection{A tradição jurídica islâmica}

Tendo em conta que este trabalho pretende avaliar as interações entre o direito islâmico e outras ordens jurídicas da sociedade mundial, faz-se necessário explicar o que se entende por direito islâmico e destacar suas características principais, cujo conhecimento proporcionará um entendimento melhor do texto, em especial dos casos a serem abordados no próximo capítulo. Espera-se, além disso, mostrar por que determinadas práticas muçulmanas não consubstanciam um fenômeno apenas religioso, como também jurídico, dado que se orientam de acordo com o código-diferença lícito/ilícito.

Autores do direito comparado tendem a descrever o Islã como "a religião da lei" (OLIVIERO, s.d.-c, p. 67), pois, de acordo com um dos estudiosos ocidentais seminais do direito islâmico, o aspecto normativo é "incomparavelmente mais importante" para a religião muçulmana do que a teologia (SCHACHT, 2008, p. 539). Essa caracterização não passou incólume pela crítica, pois ela tende a exacerbar o papel das normas de conduta atribuídas a uma ordem jurídica islâmica em detrimento de valores espirituais mais elevados para uma vida religiosa (KAMALI, 2008, p. 2 e 14). De todo modo, não se pode negar a existência do direito islâmico como parte do Islã e da identidade muçulmana, ${ }^{16}$ seja em razão de sua história, em que se identificam os problemas normativos como uma das preocupações centrais dos estudiosos religiosos, seja em razão das disputas que se observam nos países do mundo islâmico sobre o papel da $\operatorname{shar}_{\bar{l}}{ }^{\prime} a$ nas ordens jurídicas estatais contemporâneas.

O Islã surge no Século VII, em especial nas cidades sagradas de Meca e de Medina, na Península Arábica, a partir de onde se propagou, desde a revelação do livro sagrado ao profeta Maomé, seu fundador. A palavra "Islã" deriva da raiz "slm" ou "sa-la-ma", que significa submissão ou sujeição a um único Deus - Allah (COOK, 2000, p. 11; OLIVIERO, 2003, p. 5). O testemunho sincero de que "só há um Deus, e Maomé é o Seu Profeta" é o ato pelo qual uma pessoa torna-se muçulmana e um dos pilares do Islã (HOURANI, 2006, p. 201).

Quanto ao direito islâmico, há duas abordagens possíveis para explicar seu surgimento: a primeira, religiosa, coincide com a revelação do Corão e com a formação da

\footnotetext{
${ }^{16}$ Nesse sentido, cf. David (1993, p. 409): “O direito muçulmano não é, como os direitos até agora estudados, um ramo autônomo da ciência. Constitui apenas uma das faces da religião do islã. Esta comporta, por um lado, uma teologia que fixa os dogmas e determina aquilo em que o muçulmano deve crer; comporta, por outro, uma parte, o char', que prescreve aos crentes o que devem ou não fazer".
} 
comunidade muçulmana (umma); a segunda, histórica, leva em consideração a existência de um direito consuetudinário avançado nas tribos árabes pré-islâmicas, além de costumes nos territórios conquistados, que teriam passado por um escrutínio sob a ótica religiosa e dado origem gradualmente a uma tradição jurídica nova, propriamente islâmica, pari passu com a evolução das escolas jurídicas (SCHACHT, 1964, p. 2; 2008, passim), porém, priva o direito islâmico do fundamento divino que os muçulmanos atribuem a ele (OLIVIERO, s.d.-c, p. 75).

Essas possibilidades refletem a dualidade entre sharì' $a$, de um lado, e fiqh, de outro. Frequentemente, utiliza-se o vocábulo "sharī'a" como sinônimo de direito islâmico. ${ }^{17}$ Conquanto não seja errada, essa utilização é uma simplificação excessiva da tradição jurídica islâmica, na medida em que tende a reduzi-la a um conjunto de normas de conduta atribuídas a uma lei divina, relegando a um plano secundário as práticas jurídicas da comunidade muçulmana ao longo de sua história, que revelam o papel preponderante dos estudiosos na formulação de programas e de critérios normativos - a ponto de ter se tornado conhecida como “o exemplo mais típico de criação doutrinária do direito" (GAMBARO; SACCO, 2013, p. 344, tradução livre), em comparação a outros sistemas jurídicos, como a common law e a civil law, em que predominariam os formantes jurisprudencial e legislativo, respectivamente (BASSIOUNI; BADR, 2002, p. 137). ${ }^{18}$

Etimologicamente, sharī’a significa “via a seguir" (GILISSEN, 2008 [1979], p. 119; OLIVIERO, s.d.-c, p. 70). ${ }^{19}$ Em sentido amplíssimo, cabe, portanto, falar em uma sharī'a judaica, em uma sharì'a cristã e em uma sharī’a islâmica, visto que o termo abrange dogmas, ritos, preceitos morais e jurídicos revelados a judeus, cristãos e muçulmanos. Em sentido estrito,

\footnotetext{
${ }^{17}$ Por exemplo, Zweigert e Kötz definem a sharì'a nos seguintes termos em seu livro influente An introduction to comparative law: "A sharī'a, como o direito islâmico é chamado em árabe, é o conjunto de regras reveladas divinamente que o fiel muçulmano deve observar se ele busca cumprir os deveres da religião" (ZWEIGERT; KÖTZ, 1998, p. 303, tradução livre)

${ }^{18}$ Rodolfo Sacco (2001, p. 69 e ss.; GAMBARO; SACCO, 2013, p. 3-7) utiliza a categoria de "formantes do ordenamento" para designar cada um dos conjuntos de proposições doutrinárias, de máximas jurisprudenciais ou de regras legais que constituem determinada ordem jurídica e para chamar a atenção para a distinção entre o papel da dogmática e o da comparação jurídica: enquanto aquela corresponderia a um raciocínio analítico e ordenatório, esta é uma "ciência empírica fundada na observação dos modos concretos de funcionamento, nos vários sistemas, das regras especiais e das categorias ordenantes" (SACCO, 2001, p. 78).

Embora, nesse ponto do texto, tenha-se optado pelo uso da categoria "formante" para indicar os processos predominantes de formação e de modificação do direito, alinhando-o à literatura do direito comparado que a utiliza para a classificação de modelos ou de sistemas jurídicos, cabe observar que não há uma diferença clara entre essa categoria e a ideia ultrapassada de fontes formais do direito, que desconsidera as implicações do giro linguístico para a teoria do direito. No tópico deste trabalho sobre a modernidade nos países do mundo islâmico (cf. item 3.2 infra), buscar-se-á uma abordagem mais contemporânea.

${ }^{19}$ Corão, 45:18: "Então, te ensejamos (ó Mensageiro) o caminho reto da religião. Observa-o, pois, e não sigas os desejos daqueles que não têm conhecimento". Esse é o único verso do Corão em que a palavra "sharì'a" aparece (KAMALI, 2008, p. 2). Convém esclarecer que se utiliza neste trabalho a tradução do Corão para o português de Samir El Hayek, disponível gratuitamente na página da Federação das Associações Muçulmanas do Brasil: http://www.fambras.com.br/nova/media/56080971ec522.pdf. Acesso em: 06 jun. 2016.
} 
refere-se à lei revelada aos muçulmanos para regular suas obrigações (OLIVIERO, 2003, p. 6), isto é, ao Corão e à sunna do profeta, que são suas fontes sagradas, eternas e imutáveis (sobre as quais se falará um pouco mais adiante).

Na tradição jurídica islâmica, coube inicialmente ao faqīh (plural: fuqahā) ou ao 'alìm (plural: ulamāa ${ }^{20}$ a tarefa de extrair dos textos sagrados asserções claras sobre o comportamento ideal das pessoas muçulmanas. ${ }^{21} \mathrm{Ilm}$ ' al-fiqh - ou simplesmente fiqh, que em tradução literal significa “compreensão” (GLENN, 2014, p. 183; OLIVIERO, s.d.-c, p. 71) - é a ciência do direito, "a disciplina por meio da qual os estudiosos interpretam a lei e que corresponde à jurisprudência islâmica" (OLIVIERO, s.d.-c, p. 70, tradução livre). O processo de formular ou de derivar regras a partir das fontes do direito chama-se ijtihad, que se traduz literalmente como "esforço" ou "empenho" (WEISS, 1977-1978, p. 199-200), ${ }^{22}$ - mais especificamente, "o esforço de penetrar a vontade divina para formular em conformidade [com ela] as regras do direito e as normas do ritual" (JUYNBOLL, 1916, p. 22, tradução livre). Ijtihad, portanto, "é o modo islâmico de legislar" (HARASANI, 2013, p. 365, tradução livre).

\footnotetext{
${ }^{20}$ Em português, ulemá. O uso da palavra na língua portuguesa não tem o inconveniente de apontar para conceitos ou instituições próprias das ordens jurídicas ocidentais sem correspondência exata na história e no mundo islâmico - motivo pelo qual se passa a adotá-lo no restante do texto.

${ }^{21}$ John Burton diz que "À soma de prescrições resultante de seu trabalho deu-se o nome de sharī'a, o caminho a ser seguido, o 'modo de vida' verdadeiramente muçulmano que os comandos, proibições, exortações e recomendações contidas nos documentos mostraram incorporar" (BURTON, 1990, p. 12, tradução livre). No texto original em inglês, utiliza-se a forma passiva no final do período ("had been shown to embody") - dificilmente traduzível sem a modificação completa da estrutura sintática -, sugerindo que tais comandos, proibições, etc. só se permitiram mostrar incorporados aos textos sagrados a partir do trabalho dos ulemás.

Esse trecho ajuda a identificar a ambiguidade da literatura sobre direito islâmico ao descrever a sharì' $a$, de um lado, e o fiqh, de outro - especificamente, quanto a se este faria parte daquela ou se, em vez disso, comporia, separada, mas complementarmente, o que se poderia denominar "direito islâmico" ou "tradição jurídica islâmica". Essa ambiguidade pode ser atribuída ao uso polissêmico da palavra sharì'a - ora para indicar a lei revelada, insuscetível de mudanças ou adaptações; ora para fazer referência ao conjunto de todas as prescrições sobre como os crentes devem agir. Somente no segundo sentido é que cabe afirmar que o trabalho dos estudiosos gera a sharì'a. Sobre a polissemia do termo "sharì'a", cf. OTTO (2007, p. 143, tradução livre): "Em relação ao conceito de sharī'a, nós descobrimos na pesquisa que três sentidos diferentes foram ligados a ela, os quais são raramente distinguidos explicitamente um do outro. O primeiro sentido refere-se às origens divinas da sharì'a: a sharì'a é o plano de Deus e contém suas diretrizes para a comunidade de crentes. Essa definição é geral e cria espaço para manifestações diferentes da sharì'a. O segundo sentido de sharī’a é: o corpo de regras, princípios e casos redigido por fuqahā nos primeiros séculos após Maomé antes que 'o portão da interpretação livre' (ijtihad) fosse fechado. Essa definição é mais concreta e refere-se a escritos clássicos. O terceiro sentido provém da realidade infinitamente variada do mundo muçulmano contemporâneo: sharī’a então representa qualquer uma das várias interpretações possíveis da vontade de Deus por certa pessoa, grupo, instituição ou Estado que declara ser baseado 'na' sharì'a." ${ }^{22}$ Sobre a ijtihad e o papel dos doutores da lei na construção do direito, cf. Bernard Weiss (1977-1978, p. 200, tradução livre): "Estritamente falando, não é o direito como tal que é interpretado, mas em vez disso as fontes do direito. $\mathrm{O}$ direito como um produto topicamente organizado finalizado consistindo em regras formuladas em termos precisos é o resultado da interpretação jurídica; ele se coloca no final, não no começo, do processo interpretativo. Mesmo assim, não seria aceitável falar daqueles que interpretam as fontes como se em qualquer sentido estivessem criando o direito. É muito mais apropriado referir-se a esses intérpretes como alguém que descobre o direito. A teoria da ijtihad pressupõe que o processo de produção de regras é um processo de elucidação daquilo que está presente, mas ainda não autoevidente. Em princípio, o jurista muçulmano nunca inventa regras; ele formula, ou tenta formular, regras que Deus já decretou e que estão ocultas nas fontes. Essas regras, que constituem a lei ideal de Deus, existem objetivamente acima e além de todos os empreendimentos jurídicos."
} 
Atribui-se a ideia da ijtihad como método dos juristas muçulmanos a uma fala do profeta dirigida a Mu'adh Ibn Jabal, quem ele estava prestes a mandar ao Iêmen para atuar como qādi . Questionado sobre como tomaria suas decisões, Ibn Jabal respondeu que consultaria o Corão e, em seguida, a sunna e, caso não encontrasse uma solução nessas fontes, utilizaria seu próprio raciocínio, isto é, a ijtihad, ao que o profeta aquiesceu com aprovação (BASSIOUNI; BADR, 2002, p. 141, nota de rodapé n. ${ }^{\circ}$ 12; GOOLAM, 2006, p. 1446).

A ciência do direito ou fiqh divide-se em duas partes: por um lado, estuda as raízes (usūl) e articula a teoria do direito (usūl al-fiqh), que visa a explicar como e a partir de quais fontes pode-se extrair o conjunto de prescrições normativas que compõem o direito islâmico substantivo; por outro, desenvolve os ramos do direito (furū al-fiqh), isto é, as áreas temáticas com as quais os estudiosos preocupam-se e que envolvem tanto a matéria devocional ou as obrigações rituais do muçulmano ('ibadat), quanto as prescrições sobre direito de família e das sucessões, direito das obrigações, direito penal, etc. (mu' 'amalat) - o que mostra que o direito islâmico ocupa-se tanto das relações do fiel com Deus como das relações das pessoas entre si.

Diz-se, então, que "Enquanto a sharī’a é fixa e imutável, o fiqh muda e evolui de acordo com as circunstâncias em que se aplicará" (OLIVIERO, s.d.-c, p. 72, tradução livre). Nesse sentido, entende-se também que "Enquanto a sharī'a transmite-se principalmente por meio da revelação divina (wahyy) contida no Corão e em hadīth autênticos, fiqh refere-se principalmente ao corpus juris que é desenvolvido pelas escolas jurídicas (madhhabs), ${ }^{23}$ juristas individuais e juízes por meio do raciocínio jurídico e emissão de pareceres jurídicos $($ fatwāa)" (KAMALI, 2008, p. 3, tradução livre).

As escolas jurídicas - ou escolas do fiqh islâmico - não surgiram imediatamente: elas se desenvolveram durante os três primeiros séculos do Islã, ${ }^{24}$ até se consolidarem nas quatro escolas do rito sunita conhecidas hoje: as escolas hanifita, maliquita, chafiita e hanbalita. Durante o primeiro século do Islã, estudiosos muçulmanos passaram a dedicar-se ao objetivo de elaborar um sistema ideal de conduta humana (HOURANI, 2006, p. 100). Nas primeiras décadas do segundo século do Islã, o aumento da quantidade desses estudiosos religiosos importou no surgimento de escolas arcaicas do direito, "um termo que não denota qualquer organização definitiva, nem uma uniformidade rígida da doutrina no interior de cada escola, nem qualquer ensino formal, nem mesmo a existência de um corpo de previsões normativas no sentido usual" (SCHACHT, 2008, p. 550, tradução livre). Cada uma dessas escolas arcaicas é

\footnotetext{
${ }^{23}$ Madhahib (sing.: madhab), na transliteração utilizada neste trabalho.

${ }^{24}$ No Islã, o marco inicial da contagem dos séculos é a Hégira, isto é, a fuga do profeta Maomé da cidade de Meca para a cidade de Medina, que aconteceu no ano 622 da era cristã.
} 
associada a uma região - assim, havia a escola das cidades de Kufa e de Basra no Iraque, a de Medida e de Meca no Hedjaz e a da Síria - e as diferenças entre elas deviam-se principalmente a fatores geográficos, tais como as condições sociais de cada comunidade, além de costumes e práticas locais (SCHACHT, 2008, p. 550). Em meados do segundo século, surgiu o movimento tradicionalista, "baseado não em uma região (embora fosse mais forte no Iraque), mas em vez disso num princípio: a confiança exclusiva na autoridade das escrituras, sobretudo nos relatos do que o profeta, seus companheiros e os sucessores haviam dito" (MELCHERT, 1997, p. 32). Segundo Melchert (1997, p. 8), a controvérsia em torno da doutrina da criação do Corão é a causa mais provável da primeira cisão entre dois grupos mais bem definidos: ${ }^{25} \mathrm{de}$ um lado, os tradicionalistas, cujo programa consistia em coletar relatos sobre os atos e sobre as falas do profeta Maomé e dos califas que o sucederam; de outro, os adeptos do raciocínio individual $\left(r a^{\prime} y\right)$, quem os tradicionalistas acusavam de usarem instrumentos jurídicos para evitarem as exigências rigorosas indicadas por ahadīth (MELCHERT, 1997, p. 9-10).

Muitos autores atribuem a al-Shafi'i (767-820) o passo decisivo para a articulação da teoria do direito (HOURANI, 2006, p. 101; SCHACHT, 2008, p. 559-560; OLIVIERO, s.d.$c$, p. 87). Ele teria sido o responsável por identificar as quatro fontes oficiais do direito islâmico, aceitas por todas as escolas do rito sunita - o Corão, a sunna, o ijmā (consenso) e o qiyās (analogia) -, tornando-se conhecido como "o pai da jurisprudência muçulmana" (COULSON, 1964, p. 61). ${ }^{26}$ Sua tese restringe o uso da razão humana, circunscrevendo-lhe a tarefa de fazer inferências corretas a partir das fontes (SCHACHT, 2008, p. 560). Sobre a realização de alShafi'i, Noel J. Coulson afirma, elogiosamente:

“[...] a genialidade de al-Shafi'i não repousava na introdução de quaisquer conceitos novos, mas em dar às ideias existentes uma orientação, ênfase e equilíbrio novos e em fundi-las umas com as outras, pela primeira vez, em um esquema sistemático das 'raízes' do direito. Buscando suprimir o processo de desintegração na jurisprudência atual, sua teoria estabeleceu a autoridade do direito em um plano muito mais elevado por meio da transformação dos

\footnotetext{
${ }^{25}$ A doutrina da criação do Corão propunha que o livro sagrado continha a palavra de Deus, criada de modo que os árabes do Século VII pudessem entender sua mensagem eterna. Para William Montgomery Watt (2013, p. $27-$ 28), a controvérsia sobre o caráter criado ou não-criado do Corão, embora pudesse parecer uma questão teológica tola, refletia a disputa de poder que se instalou por ocasião da assim chamada "Inquisição" (mihna) entre o terceiro califa abássida, al-Ma'mun, e a instituição religiosa: "Se o Corão é a palavra criada de Deus, então ele poderia ter sido criado diferentemente, e, por conseguinte, alguém com autoridade divina (como a que era reclamada para o califa por alguns muçulmanos) poderia alterá-la. Em contrapartida, se ele não era criado [ 'uncreated'], expressaria algo da natureza de Deus e não poderia ser alterado; e neste caso a palavra final estaria com os expoentes qualificados da sharì'a, os estudiosos religiosos, e não com o califa e sua comitiva" (WATT, 2013, p. 27-28). Importa esclarecer que, ao final desse período, a tese de que o Corão é a palavra não-criada de Deus prevaleceu, tornando-se a doutrina oficial do sunismo a partir do terceiro século do Islã.

${ }^{26}$ Em sentido contrário, afirmando que al-Shafi'i não teria elaborado a "teoria das quatro fontes", mas desenvolvido ideias sobre a teoria do direito muito mais sofisticadas, cf. LOWRY (2002).
} 
elementos locais e limitados da jurisprudência das escolas arcaicas em conceitos de aplicação e validade universais para o Islã. Ao mesmo tempo, o esquema de al-Shafi'i expressava uma acomodação entre revelação divina e razão humana no direito e, portanto, esforçava-se para reconciliar o conflito básico de princípios nas escolas antigas entre o 'partido da Tradição' (ahl alhadīth) e o 'partido do raciocínio [reasoning]' (ahl al-ra'y). Era uma teoria jurídica que exprimia, com lógica irrefutável, as aspirações inatas da jurisprudência islâmica. Exposta com uma força extraordinária de persistência e singeleza de propósito, era garantia de sucesso." (COULSON, 1964, p. 61, tradução livre)

Assim, discípulos e seguidores de al-Shafi'i formaram a primeira escola "pessoal" do direito islâmico - a escola chafiita. Em seguida, as escolas de Kufa e de Medina também perfilharam o caminho da personalização em torno de eixos de autoridade - respectivamente, Abu Hanifa (700-767) e Malik ibn Anas (711-795) - dando origem às escolas hanifita e maliquita. Wael B. Hallaq assinala que a característica constitutiva de uma escola doutrinária ou madhab é "esse caráter de doutrina autoritativa cuja fonte última é presumida ser o juristamestre absoluto, o fundador" (HALLAQ, 2009, p. 34, tradução livre). No caso da escola de Kufa, a transformação pode ter se dado em razão do desafio anteriormente lançado pelos tradicionalistas e da sofisticação teórica que se seguiu a ele, enquanto, no caso da escola de Medina, ela pode ser imputada à necessidade de segurança frente à maioria pagã e cristã no Magreb: "o apelo de seguir o ensinamento de um homem teria sido sua certeza aparente, em oposição à incerteza de ter de escolher entre muitas opiniões (tradicionalismo puro) ou depender do julgamento de jurisconsultos individuais ( $r a^{\prime} y$ puro)" (MELCHERT, 1997, p. 39-40, tradução livre). Por fim, Ahmad ibn Hanbal (780-855) empresta seu nome à última escola doutrinária do rito sunita, a escola hanbalita, tida como a mais estrita em relação às fontes sagradas (GILISSEN, 2008 [1979], p. 122).

Inicialmente, a relação entre as escolas do direito islâmico não foi marcada pela tolerância, tanto que, "em Bagdá, durante o período abácida, o shafismo e o hanafismo tinham dado seus nomes a facções urbanas que lutavam umas com as outras" (HOURANI, 2006, p. 215). Entretanto, a aceitação geral do esquema das fontes do direito e a percepção da identidade de propósitos que isso produziu fizeram com que a hostilidade que existia entre as escolas em razão da pretensão de validade universal para os muçulmanos que cada uma delas possuía desse lugar à tolerância mútua gradualmente (COULSON, 1964, p. 89). Assim, a coexistência entre elas deve-se ao reconhecimento de que as inferências que elaboram exprimem possibilidades 
de interpretação da lei divina, ${ }^{27}$ a despeito de diferenças relevantes quanto a prescrições específicas de direito substantivo e quanto à extensão do uso de fontes secundárias.

Um dos fatores que pode ter contribuído para a estabilização das quatro escolas foi o chamado "fechamento dos portões da ijtihad", que teria acontecido em algum momento entre o terceiro e o sétimo século do Islã (que correspondem, aproximadamente, aos Séculos IX e XII da era cristã) (GLENN, 2014, p. 202), ${ }^{28}$ quando os estudiosos teriam chegado à conclusão de que as questões mais importantes teriam sido suficientemente debatidas e finalmente assentadas, de modo que o raciocínio independente não se faria mais necessário (SCHACHT, 1964, p. 70-71). Para Coulson, “Um respeito exagerado pelas personalidades de juristas anteriores induziu a crença de que o trabalho de interpretação e expansão fora exaustivamente completado por estudiosos de habilidade inigualável cujos esforços haviam moldado a sharì'a em sua forma final e perfeita" (COULSON, 1964, p. 81, tradução livre).

Sob outro ângulo, Bassiouni e Badr afirmam que a jurisprudência e a doutrina tornaram-se complicadas e que aqueles que as conheciam tornaram-se a elite (os conselheiros dos governantes e os professores das massas), o que explicaria "por que o clero tradicionalista sunita, a fim de preservar seu poder, decidiu no quinto século após a Hégira (Século XII d.C.) impedir o recurso à ijtihad" (BASSIOUNI; BADR, 2002, p. 146, tradução livre). Kamali, por sua vez, sustenta que o declínio da ijtihad foi uma reação ao avanço do Ocidente após 1500, o

\footnotetext{
${ }^{27}$ Sobre a relação entre as escolas do direito islâmico e o pluralismo jurídico que o caracteriza, cf. LAGE e OLIVIERO (2016).

${ }^{28}$ A ocorrência do "fechamento dos portões da ijtihad" é matéria de discussão entre os autores do direito islâmico. Entre aqueles que negam que isso tenha de fato acontecido, destaca-se Wael B. Hallaq (1984), para quem as condições para tornar-se um mujtahid, isto é, um jurista qualificado para o exercício da ijtihad, não eram tão difíceis de serem alcançadas quanto alguns autores, a exemplo de Schacht (1964, p. 72), sustentam, de modo que mujtahids teriam existido ao longo de toda a história do Islã, além de jamais se ter alcançado o consenso entre os estudiosos muçulmanos sobre a impossibilidade da ijtihad a partir de determinado momento.

Bernard Weiss (1977-1978, p. 208), após descrever a relutância dos juristas a engajaram-se na ijtihad e a transição para o taqlīd, afirma: "A noção de que no final do terceiro século (ou pouco depois) os doutores do Islã teriam alcançado um consenso imutável quanto à opinião de que ijtihad adicional seria desnecessária é insustentável. Escritores de usūl al-fiqh (teoria do direito) discutem se é possível para qualquer geração de muçulmanos ficar sem um mujtahid, mas estão longe de estarem de acordo quanto a uma resposta [a essa pergunta]. Em todo caso, afirmar que uma geração de muçulmanos poderia existir sem um mujtahid não é o mesmo que afirmar que o 'portão da ijtihad' teria sido irrevogavelmente fechado. De fato, nunca houve uma barreira permanente ao exercício da ijtihad, uma questão para a qual o reformador ocasional era acostumado a chamar a atenção. A ciência de usūl al-fiqh é largamente uma declaração das regras que regulam a ijtihad, do que seria chamado regras de interpretação na jurisprudência ocidental. Não teria sentido estudioso após estudioso devotar-se à proposição meticulosa dessas regras se ijtihad fosse nada além de uma relíquia do passado. Detecta-se em toda literatura sobre usūl al-fiqh um espírito de inquirição; interpretação parece sempre ser uma possibilidade presente, mesmo que não seja sempre uma realidade" (WEISS, 1977-1978, p. 208, tradução livre).

De todo modo, Mohamed A. Arafa ensina que, em 1983, a Organização da Conferência Islâmica estabeleceu a Academia Internacional de Fiqh para assumir o exercício da ijtihad (referência às aulas ministradas na disciplina "Islamic Law and Comparative Middle Eastern Legal and Political Studies", ofertada pelo Programa de PósGraduação em Direito da Universidade de Brasília no primeiro semestre letivo de 2016).
} 
qual teria levado os muçulmanos a adotarem uma postura conservadora "para preservarem valores e instituições tradicionais" (KAMALI, 2008, p. 169, tradução livre).

A ijtihad, então, teria sido substituída por taqlīd ("imitação"), que é a aceitação acrítica da doutrina estabelecida por predecessores: "Sob taqlīd, doutrina não era mais derivada diretamente das fontes primárias, o Corão, sunna, e ijmā (consenso dos estudioso); em vez disso, doutrina era derivada a partir das escolas de pensamento reconhecidas" (HARASANI, 2013, p. 368, tradução livre). De acordo com Kamali, "Os ulemás da era da imitação (taqlīd) ocupavam-se principalmente com comentários, compêndios e anotações marginais aos livros já escritos por juristas eminentes" (KAMALI, 2008, p. 169, tradução livre). ${ }^{29}$ No mesmo sentido, Bassiouni e Badr afirmam: "Como os ensinamentos das quatro escolas de pensamento jurídico estavam consolidadas, a produção dos estudos jurídicos assumiram um caráter não-original e comentarista" (BASSIOUNI; BADR, 2002, p. 164, tradução livre).

Embora não se possa avaliar com precisão em que medida o fechamento dos portões da ijtihad teria importado em um enrijecimento do corpo de previsões normativas que os estudiosos haviam extraído das fontes ou raízes do direito islâmico, essa exposição mostra que a estabilização das escolas jurídicas provocou mudanças na tradição jurídica islâmica. ${ }^{30}$ Instrumentos diferentes de desenvolvimento do direito islâmico adquirem maior importância em especial, a fatwā (em português, fátua), ${ }^{31}$ que é um parecer ou opinião jurídica sobre uma questão específica. ${ }^{32} \mathrm{O}$ jurisconsulto qualificado para emitir a fátua chama-se o mufti, de quem

\footnotetext{
${ }^{29}$ Embora a descrição que este trabalho apresenta sobre o direito islâmico enfatize o rito ortodoxo ou sunita, convém esclarecer, quanto ao "fechamento dos portões da ijtihad", que, a despeito de quaisquer controvérsias sobre sua ocorrência como fato histórico nas comunidades em que o sunismo prevalece, não há dúvida de que ele não aconteceu para a tradição xiita. No primeiro século do Islã, a tendência de alguns muçulmanos acreditarem que o primo e genro do profeta Maomé, Alī ibn Abī Tālib, e os descendentes deste seriam seus sucessores legítimos como líderes da comunidade muçulmana causou a primeira cisão no Islã e deu origem ao rito xiita. A tradição preponderante atualmente no xiismo reconhece uma linha ininterrupta de doze imãs e é conhecida como "Twelvers", em inglês. O último dos imãs teria ingressado em estado de ocultação no ano 874 e estaria destinado a reaparecer. Enquanto isso não acontece mantém-se a necessidade de um líder capaz de exercer o poder como representante de Deus. Então, segundo essa tradição, a ijtihad deve ser um esforço contínuo, conquanto limitada aos intérpretes mais instruídos e capazes (COULSON, 1964, p. 106; GLENN, 2014, p. 208-209). Nesse contexto, "No Irã xiita, ijtihad é a prática normal de ulemás elevados, que são explicitamente dispensados das decisões de mujtahids mortos e que têm de chegar a seu próprio julgamento" (ZUBAIDA, 2003, p. 184, tradução livre).

${ }^{30}$ Como sintetiza William Montgomery Watt (2013, p. 29, tradução livre): "Na primeira metade do Século X parece ter havido um consenso de que o portão ou a porta da ijtihad estaria agora fechada, de modo que não poderia haver mais escolas/ritos e que no futuro estudiosos religiosos seriam obrigados a seguir os precedentes estabelecidos em seu rito. Não existe registro de qualquer declaração efetiva nesse sentido, mas, como em tantos outros pontos do direito islâmico, parece ter havido um consenso informal. Pode ser que essa posição tenha sido adotada visando a defender a instituição religiosa e seus membros contra a pressão política, porque um juiz agora poderia dizer, "Eu não posso dobrar o direito como você quer, visto que sou obrigado a seguir o precedente".

${ }^{31}$ Tal como acontece com a palavra "ulemá", fatwā encontra correspondência exata na língua portuguesa ("fátua”), de modo que não existe necessidade de utilizar a transliteração do termo árabe.

${ }^{32}$ Nazeem Goolam cita a fátua que Abu al-Walid Ibn Rushd, um jurisconsulto maliquita, emitiu no ano 516 da Hégira sobre o direito exclusivo do filho de uma vítima de homicídio exigir a punição do culpado, a compensação ou perdoá-lo após atingir a maioridade como prova de que os portões da ijtihad jamais se fecharam ou, pelo menos,
} 
se espera a indicação da norma aplicável a determinado caso, seja a pedido do qāa $\bar{\imath}$ ou de uma das partes. A autoridade dessa opinião deriva das qualificações do jurista que a profere (BASSIOUNI; BADR, 2002, p. 176). Embora não tenha caráter vinculativo, "a fátua desempenhou um papel central sobretudo nos últimos séculos, como instrumento de garantia da manutenção de uma forma de interpretação por parte dos juristas islâmicos e, com ela, da possibilidade de o direito evoluir por meio da harmonização com as subculturas existentes no interior do próprio Islã" (OLIVIERO, s.d.-c, p. 115, tradução livre).

Segundo a teoria do direito (usūl al-fiqh), as fontes oficiais do direito islâmico são o Corão, a sunna, o ijmā (consenso) e o qiyās (analogia). O Corão é a primeira "raiz" do direito islâmico. Na crença muçulmana, o Corão é a palavra de Deus, que o profeta Maomé recebeu passivamente - não há qualquer elemento humano em sua formulação (WATT, 2013, p. 74). De acordo com a tradição islâmica, a revelação do livro sagrado deu-se por intermédio do anjo Gabriel, que o transmitiu oralmente a Maomé, que por sua vez o recitava a escribas, desde o ano 610 até o ano 632 d.C, quando o profeta veio a falecer. Nesse quadro de referências, a revelação não se deu de uma vez só, mas pedaço por pedaço, ao longo de um período extenso de tempo. Observam-se diferenças entre as revelações mais antigas e as mais tardias: "De acordo com Hishām ibn 'Urwa (d. cerca 763), tudo no Corão que fala sobre as comunidades e gerações do passado, ou estabelece as credenciais do Profeta, foi revelado a ele em Meca. Em contrapartida, tudo o que prescreve deveres e normas de comportamento foi revelado a ele em Medina" (COOK, 2000, p. 130, tradução livre).

Esse aspecto é relevante para a compreensão do direito islâmico; por isso, convém explicá-lo melhor. Maomé nasceu em Meca. Sua família pertencia à tribo coraixita, mas não à parte mais poderosa dela. Somente por volta dos quarenta anos de idade teve contato com o transcendente, quando um anjo o teria convocado para tornar-se mensageiro de Deus. A difusão dos ensinamentos de Maomé colocava em risco as crenças que os integrantes da comunidade coraixita compartilhavam até essa época, desgastando sua relação com as famílias em posição social mais alta. $\mathrm{O}$ agravamento da situação fez com que Maomé deixasse Meca em direção a um oásis ao norte da cidade, local que veio a ser conhecido como Medina. Lá, acumulou poder e tornou-se líder da primeira comunidade fundada em nome do Islã (HOURANI, 2006, p. 3538). Os versos do Corão cuja revelação teria se dado em Meca cumprem o propósito religioso de persuadir as pessoas a aderirem ao Islã e a seguirem seus preceitos morais, enquanto aqueles

de que "ijtihad era praticada por meio de fatwā, e como tal contribuiu para a evolução e desenvolvimento do direito substantivo no Islã medieval”' (GOOLAM, 2006, p. 1458, tradução livre). 
revelados em Medina precisavam dar respostas a problemas práticos de uma ordem social propriamente islâmica:

\begin{abstract}
"Os versículos que antecedem essa data [622 d.C.] (assim chamados mecanos) são aqueles aos quais se remonta a tradição mais pura, contendo temas de natureza religiosa e moral, enquanto os versos sucessivos, revelados em Medina, fazem referência mais à organização política do Estado que Maomé constitui na cidade. Essa segunda parte é, no entanto, muito breve, como evidencia o fato de que no texto sacro pouco espaço é dedicado aos assuntos não atinentes à religião" (OLIVIERO, s.d.-c, p. 94, tradução livre).
\end{abstract}

Para que se compreenda essa diferença, dois exemplos mostram-se úteis. A sūra do elefante é considerada tipicamente mecana (COOK, 2000, p. 130): "Não reparaste no que o teu Senhor fez com os possuidores do elefante? / Acaso, não desbaratou Ele as suas conspirações, / Enviando contra eles um bando de criaturas aladas, / Que lhes arrojaram pedras de argila endurecida, / E os deixou como plantações devastadas (pelo gado)?” (Corão, 105:1-6). Comparativamente, os versos medinenses soam, como diz Cook (2000, p. 132), mais prosaicos:

\begin{abstract}
"Os homens são os protetores das mulheres, porque Allah dotou uns com mais (força) do que as outras, e porque as sustentam do seu pecúlio. As boas esposas são as devotas, que guardam, na ausência (do marido), o que Allah ordenou que fosse guardado. Quanto àquelas de quem constatais rebeldia, admoestaias (na primeira vez), abandonai os seus leitos (na segunda vez) e castigai-as (na terceira vez); porém, se vos obedecerem, não procureis meios (escusos) contra elas. Sabei que Allah é Excelso, Magnânimo." (Corão, 4:34)
\end{abstract}

O Corão não adquiriu sua forma atual no tempo de vida de Maomé. Conta-se que as revelações foram registradas em materiais diversos e na memória dos companheiros do profeta. Seu primeiro sucessor, o califa Abū Bakr, coletou esses registros e confiou à guarda de Hafsa, a viúva do profeta. Foi o terceiro califa, Uthmān ibn Affān, quem nomeou cinco pessoas para transcreverem em um volume único o texto a partir das folhas que pediu a Hafsa, organizando-o no formato de livro (COOK, 2000, p. 119-120; BASSIOUNI; BADR, 2002, p. 148). Assim, atribui-se a Uthmān a redação oficial do Corão, por volta do ano 650 e cerca de vinte anos após a morte do profeta Maomé. Para os muçulmanos, “A autenticidade do texto do Corão e sua conformidade em relação à revelação recebida pelo Profeta estão consequentemente fora de dúvida histórica" (BASSIOUNI; BADR, 2002, p. 148, tradução livre). ${ }^{33}$ Nesse sentido, Oliviero explica:

\footnotetext{
${ }^{33}$ Cf. também JUYNBOLL (1916, p. 5-6), relatando a história da redação oficial do Corão e ressaltando a
} impossibilidade de duvidar-se da autenticidade do texto. 


\begin{abstract}
"Para o mundo islâmico, nunca se colocou o problema das fontes do Corão, na medida em que é unanimemente aceita a teoria da revelação direta por parte do arcanjo Gabriel ao profeta Maomé. Segue-se que a ideia de inspiração divina do Corão é decisivamente diversa daquela usualmente considerada na tradição cristã. No Corão, cada palavra é inspirada e sagrada na medida em que é a tradução exata do 'Livro sagrado que está no céu com Deus'. Nesse sentido, o Corão é 'palavra de Deus', entendida mais como verbum mentis Dei do que como expressão fonética. Se na Bíblia a ideia fundamental é inspirada por Deus e o autor sacro exprime depois com suas próprias palavras, mais ou menos adequadas segundo sua preparação cultural e sua tradição social, quando lhe foi inspirado, no Corão isso não pode absolutamente acontecer. Os redatores do Velho e do Novo Testamento são assim considerados 'autores' dos seus textos, enquanto o mesmo não se pode dizer do Profeta. Para a doutrina islâmica, é uma grave blasfêmia sustentar o contrário, porque o único autor do Corão é Allāh" (OLIVIERO, 2014, p. 597, tradução livre)
\end{abstract}

O Corão é organizado em cento e catorze capítulos, cada um dos quais chamado sūra e dividido em versículos chamados 'ajat. À exceção do capítulo um, a Fātiḥa (abertura), as sūras aparecem na ordem aproximada de sua extensão - da mais longa à mais curta -, não na ordem cronológica de sua revelação. Há no total 6.239 versos, entre os quais cerca de quinhentos têm conteúdo jurídico ${ }^{34}$ - vale dizer, contêm previsões normativas atinentes ao direito de família e das sucessões, ao direito das obrigações e dos contratos, ao direito penal e ao direito processual (BASSIOUNI; BADR, 2002, p. 148-149; OLIVIERO, s.d.-c, p. 93-94). Eles são frequentemente chamados āyāt al-aḥkām (versos jurídicos) ou al-ahkām al- 'amaliyyah (determinações práticas ou practical rulings, em inglês) (KAMALI, 2008, p. 19). Pode-se citar como exemplo de verso jurídico o seguinte: "Concedei os dotes que pertencem às mulheres e, se for da vontade delas conceder-vos algo, desfrutai-o com bom proveito" (Corão, 4:4). Nele, impõe-se o presente nupcial ou dote como condição de validade do contrato de matrimônio (JUYNBOLL, 1916, p. 137; SCHACHT, 1964, p. 161). Além disso, as determinações corânicas podem ser claras e inequívocas (qat '`̣̂) ou, em vez disso, especulativas (zannī), sujeitas à ijtihad (KAMALI, 2008, p. 22-23).

Quando se verifica a existência simultânea de determinações divinas sobre o mesmo tema e com sentidos incompatíveis, aplica-se a teoria de naskh - que corresponde, grosso modo, à regra da ab-rogação. ${ }^{35}$ Segundo Burton, “A teoria de naskh é baseada, então, em um conceito

\footnotetext{
${ }^{34}$ De acordo com Kamali (2008, p. 19-10), o Corão teria trezentos e cinquenta "versos jurídicos". O autor ressalta a existência de divergência entre os ulemás quanto aos números, tendo em conta que isso depende da compreensão de cada um sobre o conteúdo do livro sagrado. Entretanto, a maior parte dos autores do direito islâmico estima a quantidade de versos jurídicos em aproximadamente quinhentos, como exposto acima.

${ }^{35}$ Segundo Oliviero (2014, p. 598), a regra da ab-rogação está prevista no seguinte verso corânico: “Allah contesta ou confirma o que Lhe apraz, porque o Livro-matriz está em Seu poder” (Corão, 13:39).
} 
do desenvolvimento gradual da revelação. A teoria não sugere, sob essa ótica, a mutabilidade da Vontade Divina" (BURTON, 1990, p. 20, tradução livre). O faqīh deve preocupar-se primeiramente com o sentido das determinações aparentemente conflitantes e buscar uma interpretação que as reconcilie. Somente quando isso se mostrar impossível e elas se provarem excludentes é que se investigam as circunstâncias em que cada revelação aconteceu, a fim de estabelecer suas respectivas datas. Seguindo essa linha de raciocínio, deve-se favorecer a revelação mais recente e abandonar a mais antiga (BURTON, 1990, p. 26).

Somando-se à quantidade relativamente pequena de versos jurídicos ou determinações práticas, a necessidade de conhecer as circunstâncias de cada revelação ajuda a evidenciar a importância da segunda fonte oficial do direito islâmico: a sunna do profeta - ou seja, prática do profeta, tal como seus atos e pronunciamentos expressam. A autoridade da sunna como fonte do direito islâmico, para Bassiouni e Badr (2002, p. 150), deriva do Corão: "Dize: Obedecei a Allah e ao Mensageiro! Mas, se se recusarem, saibam que Allah não aprecia os incrédulos" (Corão, 3:32). ${ }^{36}$ Oliviero destaca o verso de acordo com o qual as ações do profeta são inspiradas divinamente (OLIVIERO, s.d.-c, p. 95): "Nem fala por capricho. Isto não é senão a inspiração que lhe foi revelada" (Corão, 53:3-4).

A sunna é composta pelos relatos de falas e atos do profeta. Cada um deles denomina-se hadìth (pl.: ahadīth). Estes, por sua vez, têm duas partes: “A primeira contém o nome das pessoas que uma depois da outra transmitiram o conteúdo da tradição, do último narrador ao testemunho originário. Essa parte do hadīth chama-se isnād (ou também sanad), isto é, 'o apoio' (para credibilidade da notícia)” (JUYNBOLL, 1916, p. 9, tradução livre); a segunda corresponde ao texto propriamente dito (ou seja, ao conteúdo da tradição). ${ }^{37} \mathrm{O}$ hadīth a seguir exemplifica essa explicação:

\footnotetext{
"Recebemos de 'Abdassalam Ibn 'Adal Wahab al Asbahani, de acordo com Suleyman Ibn Ahmad Ibn Ayyub At Tabarani, de acordo com Yahia Ibn 'Uthman Ibn Salah, de acordo com Na'im Ibn Hammad, de acordo com 'Isa Ibn Yunus, segundo Jarir Ibn 'Uthman, segundo 'Abdarrahman Ibn Jubair Ibn Nufair, segundo seu pai, segundo 'Aouf Ibn Malik, que Deus se compraza nele, que relata que o Mensageiro de Deus disse: 'Minha comunidade se dividirá em mais de setenta seitas, sendo a mais perigosa delas aquelas cujos membros tratam as coisas pela livre opinião, autorizando o pecado e proibindo o lícito'." (apud PLANTIN, 2008, p. 132-133)
}

\footnotetext{
${ }^{36}$ Os autores citam também os versos 3:132, 4:50, 24:54 e 4:59 (BASSIOUNI; BADR, 2002, p. 150, nota de rodapé . $\left.^{\circ} 44\right)$.

37 Plantin explica que "O hadīth é composto, portanto, de uma proposição e de sua 'garantia'. É um topos substancial, como os que foram coletados nas compilações de lugares comuns ('commonplace books') do Renascimento, com a ressalva de que os ahadīth têm uma legitimidade exclusivamente religiosa." (PLANTIN, 2008, p. 134)
} 
Durante os primeiros séculos do Islã, centenas de milhares de ahadīth estavam em circulação. De acordo com Schacht, “em razão do sucesso da tese principal dos Tradicionalistas, a maior parte do que originalmente havia sido decisões discricionárias e resultado do raciocínio individual pelos estudiosos foi colocado na boca do Profeta" (SCHACHT, 1964, p. 40, tradução livre). Por isso, fizeram-se necessários estudos sobre a autenticidade dos relatos - um campo específico de pesquisa chamado 'ilm al-hadīth. Os critérios de avaliação da credibilidade de um relato levam em consideração seu conteúdo, que deve ser lógico e compatível com o Corão e com ahadīth autênticos, assim como a cadeia de transmissão (isnād). Os narradores devem ser confiáveis e quaisquer pessoas que tenham transmitido uma à outra o conteúdo da tradição devem ter sido contemporâneas e vivido na mesma cidade ou, pelo menos, terem comprovadamente se encontrado em algum momento. Os xiitas exigem também que o relato originário provenha de um membro da família do profeta (BASSIOUNI; BADR, 2002, p. 151). Conforme sua credibilidade, ahadīth classificam-se em sólidos ou seguros (șaḥihh), ${ }^{38}$ satisfatórios (hasan), ${ }^{39}$ ou fracos (da îf $) .{ }^{40}$ Não existe uma compilação oficial de ahadīth, apenas algumas coleções de reputação elevada entre os estudiosos muçulmanos que datam do terceiro século da Hégira (JUYNBOLL, 1916, p. 13). ${ }^{41}$

O Corão e a sunna são as fontes sagradas do direito islâmico. Eles estabelecem o conjunto de obrigações que os fiéis muçulmanos devem seguir para uma vida virtuosa e para a salvação no Juízo Final. Como fontes sagradas da sharī'a, provêm níveis de distinção entre o jurídico, o moral e o religioso, dividindo as condutas humanas em uma escala que vai do obrigatório (farḍ ou wājib) ao proibido (harām), passando por ações recomendáveis (mandūb), indiferentes ou permissíveis (ja'iz ou mubāhn) e repreensíveis (makrūh). Somente o obrigatório e o proibido são adjudicáveis - as demais categorias localizam-se no campo ético e religioso, promovendo virtudes para uma vida boa sob a ótica religiosa (KHADDURI, 1953-1954, p. 89; KAMALI, 2008, p. 18). ${ }^{42}$ Nesse sentido, pode-se dizer que existem operações na tradição islâmica que se sujeitam a um código-diferença lícito/ilícito, o qual possibilita a identificação

\footnotetext{
${ }^{38}$ Em inglês, "sound" (BURTON, 1994, p. 111); em italiano, "sane" (JUYNBOLL, 1916, p. 12).

${ }^{39}$ Em inglês, "fair" (BURTON, 1994, p. 111); em italiano, "buone" (JUYNBOLL, 1916, p. 12).

${ }^{40}$ Em inglês, "weak" (BURTON, 1994, p. 111); em italiano, "deboli" (JUYNBOLL, 1916, p. 12).

${ }^{41}$ Além da exigência de que o narrador original pertença à família do profeta, outra diferença dos xiitas em relação aos sunitas é que aqueles rejeitam os chamados "seis livros corretos", isto é, as coleções de ahadīth que os sunitas reputam críveis, substituindo-os por cinco coleções próprias. Mesmo assim, as diferenças concentram-se mais nas cadeias de transmissão (isnād) do que no conteúdo propriamente dito da tradição (KAMALI, 2008, p. 89-90).

${ }^{42}$ Khadduri cita os seguintes exemplos: "as preces diárias ou o jejum no mês do Ramadã são farḍ; carne de porco, vinho e usura são harām; qualquer prece adicional é mandūb; certos tipos de peixe são makrūh; mas todas as outras atividades que não se enquadram nessas categorias são ja 'iz" (KHADDURI, 1953-1954, p. 9, tradução livre).
} 
do sistema jurídico (LUHMANN, 2005, p. 225; NEVES, 2012, p. 67), mesmo que não seja um código estritamente binário, mas analógico, como essa escala de cinco valores mostra.

No fiqh islâmico, não há sempre acordo entre os fuqahā ou ulemás sobre o sentido e sobre o alcance das determinações corânicas especulativas, sobre a classificação de determinado hadīth como sólido, satisfatório ou fraco, tampouco sobre o caráter obrigatório, proibido, recomendável, indiferente ou repreensível de um ato. Além disso, as fontes sagradas não oferecem respostas a todas as questões jurídicas que se colocaram após a morte do profeta. Por isso, o direito islâmico tem também fontes, por assim dizer, humanas.

Nesse contexto, a terceira fonte ou "raiz" do direito islâmico é o consenso (ijmā). O consenso refere-se ao acordo da comunidade muçulmana em torno de determinada solução. Malik ibn Anas - fundador da escola maliquita - teria sido o primeiro a introduzir o consenso (ijmā) como procedimento para selecionar quais ahadīth seriam aceitáveis. Para ele, "o acordo dos juristas de Medina quanto a uma regra jurídica baseada em um hadith (que pode ter sido um costume local incorporado em um hadìth, ou por um hadìth, em falta de autenticidade, circulado para sancioná-lo) constituía direito" (KHADDURI, 1953-1954, p. 14, tradução livre).

Embora, por definição, ijmā correspondesse ao acordo da comunidade muçulmana - umma - como um todo, assentou-se a concepção de acordo com a qual o consenso dos juristas qualificados para a ijtihad - os mujtahid - é uma fonte de regras jurídicas novas, quando eles expressam a mesma opinião a respeito de uma questão específica. A despeito do temor de que o consenso pudesse configurar legislação por homens (opondo-se, portanto, ao dogma da origem divina da sharì'a), atribui-se a legitimidade dessa fonte a um hadìth do profeta Maomé de acordo com o qual "minha comunidade jamais concordará em um erro" (JUYNBOLL, 1916, p. 31; KHADDURI, 1953-1954, p. 19; BASSIOUNI; BADR, 2002, p. 153), assim como a um verso corânico, que diz: “A quem combater o Mensageiro, depois de haver sido evidenciada a Orientação, seguindo outro caminho que não o dos crentes, abandoná-lo-emos em seu erro e o introduziremos no inferno" (Corão, 4:115). Além disso, Maomé disse que "os doutos são herdeiros dos Profetas" (KHADDURI, 1953-1954, p. 14, tradução livre). ${ }^{43}$

Uma vez alcançado, o consenso entre os juristas de determinada época torna-se vinculante para os integrantes daquela escola jurídica ou madhab. ${ }^{44}$ Para Juynboll (1916, p. 31-

\footnotetext{
${ }^{43}$ A doutrina da infalibilidade do ijmā consolidou-se gradualmente, passando por diversas fases. Inicialmente, propôs-se como aceitável somente o consenso da șaḥābah, isto é, a comunidade mais antiga, dos contemporâneos ou dos companheiros do profeta. Outros propunham que se levasse em consideração o ijmā das duas cidades santas, Meca e Medina; ou, ainda, o ijmā al-tabi 'in, ou seja, o consenso dos sucessores (JUYNBOLL, 1916, p. 30-31; OLIVIERO, s.d.-c, p. 97).

${ }^{44}$ Maurizio Oliviero explica que o ijmā é indissociável de uma das instituições mais importantes do direito islâmico, a shūrā, isto é, a consulta, que está prevista no Corão: “Que atendem ao seu Senhor, observam a oração,
} 
32), a autoridade do fiqh deriva do $i j m a \bar{a}$, porque, se por um lado o Corão e a sunna são as fontes principais do direito islâmico, por outro seu significado está sujeito a uma diversidade grande de opiniões, de modo que somente o ijma $\bar{a}$ teria satisfeito a necessidade de uma interpretação segura da vontade divina. Sob outra perspectiva, Kamali também destaca a importância do consenso para a evolução da ordem jurídica islâmica:

"Como uma fonte vinculante do direito, a vontade coletiva e o consenso (ijmā) das pessoas e de seus estudiosos garante continuidade assim como adaptação à mudança por meio da introdução de novas leis que reflitam as necessidades legítimas da comunidade e a visão de seus estudiosos. Ijmā é um veículo, em teoria pelo menos, para evolução de ideias e para integrar as realizações educacionais e culturais da comunidade no tecido da sharī'a." (KAMALI, 2008 , p. 53, tradução livre)

Exemplificativamente, diante da determinação corânica de que os pais devem receber um sexto da herança deixada pelos filhos, surgiu a dúvida quanto ao que receberiam os avós se os pais tivessem falecido antes dos filhos. Os juristas muçulmanos chegaram ao consenso de que, na ausência dos pais do autor da herança, os avós devem receber seus respectivos quinhões. Outro exemplo diz respeito à proibição ao consumo de carne suína. Quanto a ela, alcançou-se o consenso de que inclui a vedação à gordura do porco (BASSIOUNI; BADR, 2002, p. 153-154).

Finalmente, a quarta fonte oficial do direito islâmico é o qiyās, que consiste, "segundo a definição técnica dos doutores muçulmanos, no transferir um preceito da raiz (ou seja, do caso expressamente formulado nas fontes sagradas) a um ramo (ou seja, a um caso novo não indicado no texto" (JUYNBOLL, 1916, p. 32, tradução livre, itálico no original). Trata-se, em poucas palavras, da analogia, com a particularidade de que o direito islâmico não a admite para a criação de regras novas que não estejam previstas no Corão ou na sunna. ${ }^{45}$ Trocando em miúdos, isso significa que a analogia deve partir de um verso corânico ou de um

\footnotetext{
resolvem os seus assuntos em consulta e fazem caridade daquilo com que os agraciamos" (Corão, 42:38). Segundo o autor, "a consulta torna-se a técnica que permite a participação de todos os crentes, de modo que se não há shürā, não pode haver ijmä" (OLIVIERO, s.d.-c, p. 98).

Em contrapartida, Kamali afirma: "Enquanto shürā era uma prática árabe arraigada, e essencialmente democrática, ela não tinha caráter vinculante. Na história do governo islâmico também, shūrā não constituiu um freio sobre os poderes do califa" (KAMALI, 2012, p. 29, tradução livre). Portanto, a afirmação contundente de um vínculo entre o ijma como fonte do direito islâmico e a shürā dependeria de um aprofundamento da pesquisa quanto a esse aspecto específico, fugindo ao escopo deste trabalho.

${ }^{45}$ Quanto a esse aspecto, o qiyās difere do ijm $\bar{a}$ (OLIVIERO, s.d.-c, p. 99), por meio do qual se pode determinar uma regra nova, conforme exposto anteriormente.
} 
hadìth - não existe algo parecido com o princípio do stare decisis na common law, o que reduz a possibilidade de inovações reprováveis. ${ }^{46}$

O uso de analogias ou qiyās como método de dedução foi objeto de disputa entre os tradicionalistas (ahl al-hadīth) e os adeptos do raciocínio individual (ahl al-ra’y). Para aqueles, qualquer dedução constituiria uma invenção do diabo. Porém, com o passar do tempo e com a articulação da teoria do direito (usūl al-fiqh) - tal como se descreveu acima -, as escolas do rito ortodoxo passaram a aceitá-la como fonte do direito islâmico, concentrando a discussão em torno da forma que ela deve assumir para demonstrar-se correta (JUYNBOLL, 1916, p. 33). Uma inferência correta a partir das fontes sagradas tem a forma de um silogismo lógico, que, para os juristas muçulmanos, equivale ao raciocínio por analogia (HALLAQ, 1997, p. 83). Segundo Hallaq (1997, p. 83), os tratados de usūl al-fiqh dedicam-se extensivamente à discussão sobre o argumento por analogia, em especial para identificar seus elementos, que são: o caso original ( $a s ̣ l)$, previsto no Corão ou na sunna; o caso novo ( $f a r{ }^{\circ}$ ), que requer uma solução; a ratio legis ('illa), que é uma conexão causal ou um atributo comum a ambos; por fim, a regra jurídica $(h u k m)$, que, em razão da semelhança entre eles, transfere-se do caso original para o inédito (HALLAQ, 1997, p. 83). ${ }^{47}$

O exemplo típico de uso de qiyās diz respeito a bebidas alcoólicas e substâncias entorpecentes. O Corão proíbe o consumo do vinho - essa é a determinação corânica original $(a s ̣ l)$. O surgimento de um produto alcóolico novo ou de um narcótico demanda a normatização, com referência às categorias da proibição, permissão, recomendação etc. A razão ou 'illa subjacente à vedação ao vinho é sua qualidade inebriante, que impede o fiel muçulmano de cumprir suas obrigações religiosas adequadamente. Outras bebidas alcóolicas e substâncias entorpecentes produzem o mesmo efeito inebriante. Logo, elas também são proibidas (HALLAQ, 1997, p. 83-84; BASSIOUNI; BADR, 2002, p. 156; OLIVIERO, s.d.-c, p. 99).

Somando-se à exigência da constatação de uma conexão causal ou atributo comum ( 'illa) como condição de validade de um raciocínio por analogia, estudiosos muçulmanos

\footnotetext{
${ }^{46}$ Christian Plantin cita uma alegoria que um dos autores clássicos do direito islâmico utiliza para justificar essa restrição: "Al-Ghazâli justifica essa proibição comparando o trabalho de inferência 'ao trabalho de alguém que tenta encontrar, na praia, conchas que se assemelhem. Tão logo encontre uma concha que se parece com a original, ele lança fora a original e se põe a buscar uma concha que se assemelhe à segunda, e assim por diante. Quando tiver encontrado a décima, não ficará surpreso ao constatar que ela é totalmente diferente da primeira da série"” (PLANTIN, 2008, p. 139).

${ }^{47}$ Há uma semelhança entre a elaboração da teoria do direito islâmico sobre analogia e o silogismo descrito nos Analíticos Anteriores de Aristóteles (em especial, de 24a10 a 28a10, cf. ARISTÓTELES. Órganon. 2. ed. Trad. Edson Bini. Bauru, SP: Edipro, 2010, p. 111-123). Os árabes muçulmanos tiveram contato com a cultura helenística no Crescente Fértil (SCHACHT, 1964, p. 20-21), de modo que a influência aristotélica é possível. Entretanto, a confirmação dessa hipótese requer o aprofundamento do estudo sobre a história da teoria do direito islâmico e sobre os tratados de usūl al-fiqh, o que não é objeto específico da pesquisa que subsidia este trabalho.
} 
passaram a sustentar que um jurista adequadamente treinado seria capaz de inferir determinados interesses ou objetivos da sharì'a a partir das escrituras sagradas, destinados a garantir um benefício ou a repelir um dano. Desse modo, criou-se a doutrina dos objetivos da sharī'a (maqasid al-sharī'a). São fundamentalmente cinco: a religião, a vida, o intelecto ou juízo perfeito, a prole ou linhagem familiar e a propriedade. Alguns juristas acrescentam a honra. Esses objetivos são tidos como necessários, colocando-se em posição de primazia em relação a interesses adicionais (GOOLAM, 2006, p. 1450-1451; LOMBARDI; BROWN, 2006, p. 400401). Conforme a doutrina dos objetivos da $\operatorname{sharì’}^{\prime}$, uma analogia correta depende não só da consistência lógica, como também da identificação do propósito a que o texto sagrado visa a atender. Nesse sentido, Lombardi e Brown explicam:

\begin{abstract}
"Se um jurista quisesse desenvolver com confiança um direito por analogia em relação a uma determinação escritural, ele precisaria entender o interesse que a determinação escritural subjacente promove. Tendo derivado uma regra que, ele pensava, fosse análoga à regra escritural, ele confirmaria sua conclusão perguntando se a regra nova favoreceria o mesmo interesse que a regra escritural subjacente. Isso significava que uma regra derivada por analogia era de validade contingente. Ela deixava de ser aplicável sempre que circunstâncias mudassem tão dramaticamente que ela não promovesse eficazmente os objetivos a que deveria servir." (LOMBARDI; BROWN, 2006, p. 401, tradução livre $)^{48}$
\end{abstract}

Há também fontes secundárias ou suplementares, além do Corão, da sunna, do ijmā (consenso) e do qiyās (analogia). Todavia, em relação a elas, não existe consenso entre as escolas doutrinárias do direito islâmico, seja quanto à sua legitimidade, seja quanto à extensão da possibilidade de sua utilização. Entre as fontes não-oficiais, destacam-se a istislah ou malaha (considerações sobre o interesse público, que visam a garantir um benefício ou a prevenir um dano, de acordo com os objetivos da sharī'a); a istihsan (exercício da opinião pessoal para evitar a rigidez e a injustiça que a adoção do sentido normativo mais literal poderia provocar, semelhante à equidade nas ordens jurídicas ocidentais contemporâneas); o $\operatorname{urf}$ (usos e costumes, que correspondem às práticas cotidianas das pessoas e das comunidades locais, desde que não contradigam uma determinação contida nas fontes primárias); os contratos, entre outros.

De modo geral, as escolas doutrinárias do direito não divergem acerca de matérias devocionais ou obrigações rituais dos muçulmanos ('ibadat). Afirma-se, pois, que a analogia e

\footnotetext{
${ }^{48}$ Pode-se especular em que medida a doutrina dos objetivos da sharī'a caracteriza-se como um mecanismo reflexivo da ordem jurídica islâmica. Este trabalho não tenta oferecer uma resposta a essa questão. Ele a apresenta como uma possibilidade de leitura da doutrina dos objetivos da sharī'a, por exemplo, na jurisprudência da Suprema Corte Constitucional do Egito, conforme se discutirá adiante, quando se abordará o caso Mahmud Sami Muhammad 'Ali Wasil v. o Ministro da Educação (Caso n. ${ }^{\circ} 8$ do Ano Judicial 17, de 18 de maio de 1996).
} 
a opinião pessoal do jurista não se aplicam a esse ramo do direito islâmico, por dois motivos: em primeiro lugar, ele contém o núcleo da fé muçulmana, ao qual o fiel deve se submeter sem questionar; em segundo, diz-se que as fontes sagradas provêm instruções específicas sobre 'ibadat, ao mesmo tempo em que explicitam apenas os objetivos básicos e os princípios gerais do mu 'amalat, os quais são abertos à análise e à ijtihad (KAMALI, 2008, p. 43).

Os atos e rituais que compõem o 'ibadat chamam-se comumente "pilares do Islã". O primeiro deles é o schahādah, mencionado no início deste tópico: trata-se do testemunho de que só há um Deus, e Maomé é o Seu Profeta. Esse testemunho é o que distingue o fiel muçulmano "dos descrentes e dos politeístas, e também dos judeus e dos cristãos, que se incluíam na mesma tradição de monoteísmo: que só há um Deus, que Ele revelou Sua Vontade à humanidade através de uma linha de profetas, e que Maomé é o Profeta em que a linha culmina e termina, 'o Selo dos profetas"” (HOURANI, 2006, p. 201). ${ }^{49}$

O segundo pilar do Islã é șalāt, a prece ritual que o muçulmano em posse de suas faculdades mentais e púbere deve praticar cinco vezes ao dia, em horários determinados e em posição voltada a Meca. ${ }^{50}$ Mesquitas anunciam o momento exato da prece por meio de uma convocação chamada ad̄ān ou azan. O terceiro pilar é o zakāt. No tempo de Maomé, ele correspondia à obrigação de caridade (doações a pessoas pobres, libertação dos escravos, alojamento aos viajantes, etc.). Posteriormente, assumiu o significado de imposto ou dízimo, em percentuais que o direito islâmico define com precisão. O quarto é o jejum no mês do Ramadã, durante o qual muçulmanos não podem comer, beber ou praticar relações sexuais entre o nascer e o pôr do sol, dispensando-se apenas os doentes e viajantes, as mulheres grávidas e lactantes e as pessoas idosas que já não suportem jejuar. O quinto e último pilar do Islã é a peregrinação a Meca, que todo fiel deve fazer ao menos uma vez em sua vida. Cada uma dessas obrigações rituais tem condições de validade específicas - exemplificativamente, a șalāt exige que a pessoa, sua roupa e o local em que fará a prece estejam limpos; fumar tabaco ou ópio torna o jejum inválido; porém, as sanções para o desatendimento a esses deveres são precipuamente religiosas, relacionadas à salvação do fiel muçulmano (JUYNBOLL, 1916, p. 37-101; HOURANI, 2006, p. 200-205).

\footnotetext{
${ }^{49} \mathrm{Na}$ tradução do Corão que se utiliza neste trabalho, lê-se que Maomé é "o derrareiro dos profetas”. Porém, como as referências em língua inglesa mostram ao traduzir a expressão árabe khātam an-nabìyin como "the seal of the prophets", "o selo dos profetas" é uma tradução possível para referir-se ao dogma islâmico de que Moisés e Jesus Cristo também teriam sido profetas de Deus, mas Maomé seria o último dos profetas e o Corão, a revelação em sua forma final e perfeita. No próximo capítulo, abordar-se-á um caso constitucional da Suprema Corte do Paquistão em que essa questão colocou-se de modo central.

${ }^{50}$ Segundo Juynboll, não obstante o direito islâmico clássico considere a șalāt o pilar mais importante do Islã, "como facilmente se compreende, um tal dever, que se é obrigado a cumprir tão frequentemente, em todas as regiões muçulmanas é há muito tempo negligenciado às vezes” (JUYNBOLL, 1916, p. 45, tradução livre).
} 
Essa exposição espera cumprir o objetivo de apresentar o leitor ou a leitora a pontos relevantes da dogmática do direito islâmico clássico, ainda que sem pretensão de completude. Ela autoriza a asserção de que a tradição islâmica contém uma ordem jurídica complexa (OLIVIERO, 2014, p. 595): “Tradições complexas, então, alcançam o nível de complexidade, e de serem tradições grandes, em função de sua capacidade de lidar com diversidade, contradição e demandas por aquilo que normalmente se conhece como mudança" (GLENN, 2014, p. 367, tradução livre).$^{51}$ É a diversidade de soluções possíveis para problemas jurídiconormativos que permite a afirmação da complexidade.

Em conclusão a este tópico, convém retomar a linha histórica de exposição com que ele se iniciou. Viu-se que Maomé criou uma organização política em nome do Islã, no ano 622, em Medina, a partir de onde a religião espraiou-se. Os chefes políticos da comunidade muçulmana que se seguiram a Maomé chamam-se califas (khalïfa) ou sucessores do profeta. Os quatro primeiros, Abū Bakr (632-634), Umar ibn al-Khattāb (634-644), Uthmān ibn Affān (644-656) e Alī ibn Abī Tālib (656-661), são conhecidos como califas corretamente guiados eram companheiros do profeta, que haviam convivido com ele e que teriam alguma autoridade religiosa. Os parentes de Uthmān opuseram-se a Alī, cujo assassinato levou à ascensão de Mu'awiya ibn Abi Sufyan e da dinastia omíada (661-750). O mapa abaixo mostra a expansão do califado até essa época (Figura 1). A dinastia abássida instalou-se no Iraque, em 750. Perdurou até 1258, quando a invasão dos mongóis a Bagdá derrubou-a.

\footnotetext{
${ }^{51}$ Sob a perspectiva histórica, cf. HOURANI (2005, p. 29): “Aos poucos, os costumes e as práticas da sociedade islâmica primitiva, muitos herdados dos mundos pré-islâmicos - de Bizâncio, da Pérsia e da Arábia pagã -, foram absorvidos pelo corpo da lei islâmica; talvez fosse mais correto dizer que a lei islâmica foi criada pela mistura desses costumes e práticas com os princípios e os editos tirados do Corão e do hadith autêntico. Sem dúvida, esse processo implicava alguma 'adulteração' da lei e da tradição, a criação de novas tradições para dar uma capa de respeitabilidade islâmica ao que não era de origem islâmica; mas também operava no sentido contrário, pela seleção de costumes e práticas, pela rejeição de alguns e pela aceitação de outros, e até pela modificação daqueles que eram aceitos à luz do ensinamento do Islã. Por esse processo lento, jamais completado e jamais capaz de ser completado, os sistemas de muitos países convertidos ao Islã foram permeados pelas suas idéias morais, e criouse uma sociedade islâmica profundamente unificada".
} 
Figura 1. O califado em $750^{52}$

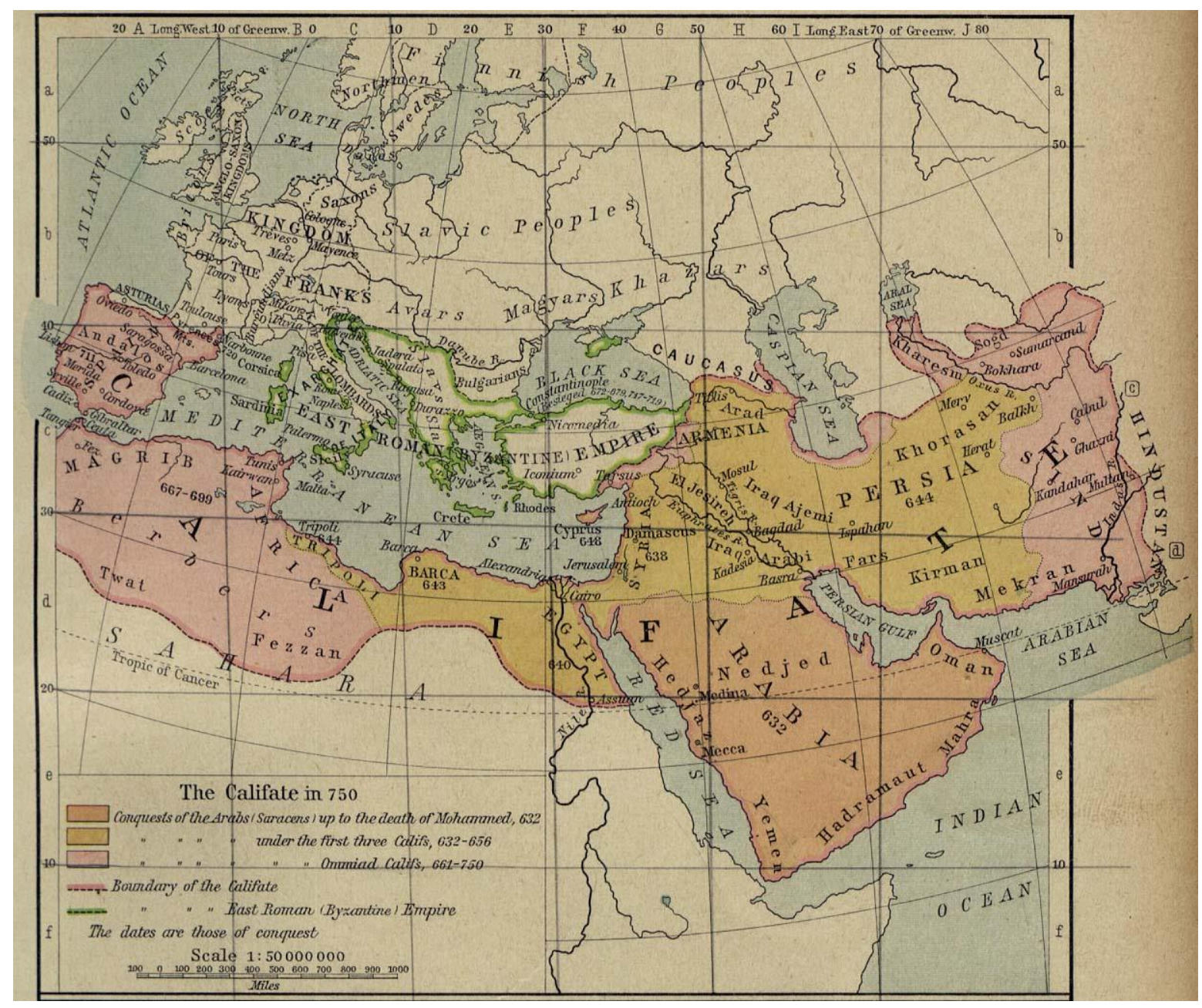

Não se pretende traçar a história do califado. Mencionam-se essas transições apenas com o objetivo de explicar um aspecto final. A "fase de ouro" do direito islâmico coincide aproximadamente com o período do califado abássida, quando se dá a consolidação das escolas doutrinárias do rito sunita, dos conceitos e das instituições principais da ordem jurídica islâmica (OLIVIERO, s.d.-c, p. 82). Após a invasão dos mongóis a Bagdá, o califa perde o poder político, tornando-se uma figura secundária na corte dos sultões mamelucos do Egito. ${ }^{53}$ Desde então,

\footnotetext{
${ }^{52}$ Mapa em domínio público. "The Califate in 750”, In: The Historical Atlas, de William R. Shepherd (1926). Disponível em: http://www.lib.utexas.edu/maps/historical/shepherd/califate 750.jpg. Acesso em 26 jul. 2016.

${ }^{53}$ Faz-se necessário esclarecer que a dissolução da unidade política do califado acontece por um processo histórico mais lento do que essa passagem leva a entender, visto que inclui o refúgio da família omíada na Espanha, onde governa por quase três séculos, com sua capital em Córdoba; a criação da dinastia fatímida no Magreb; a perda de poder dos abássidas para os mercenários turcos de quem dependiam cada vez mais.

Tem-se consciência de que o texto não faz jus à história dos povos árabes e muçulmanos. Porém, ele não tem a intenção de apresentar um relato histórico das mudanças políticas, citando-as apenas na medida em que forem necessárias para a compreensão da ordem jurídica islâmica.
} 
grupos militares passaram a exercer o poder sobre as comunidades da região, o que provocou uma mudança no papel da sharī'a:

\begin{abstract}
"O sultão podia ser formalmente investido pelo califa, mas não havia segredo de que o seu poder se baseava na usurpação ou na herança, e não no que fora considerado pelos juristas o processo legítimo de escolha - quer essa escolha fosse exercida pela shura, quer pelo califa anterior. Embora a Charia e os seus juízes fossem respeitados, ao seu lado havia os editos e as decisões do sultão, ministrados por ele ou seus funcionários na câmara de audiências. Assim, a Charia tendia a ser nada mais do que um princípio negativo, algo que o governante não podia transgredir, e não algo que dirigisse sua conduta; o objetivo positivo do regente era manter e reforçar a sua autoridade, e usar a Charia, à luz da equidade natural ou interesse do Estado, para regular as diferentes classes da sociedade." (HOURANI, 2005, p. 32)
\end{abstract}

Em face dos editos dos sultões ou qanun - como também são chamados -, estudiosos muçulmanos desenvolveram a teoria da siyāsa shar 'iyya: governantes ou detentores do poder coercitivo (wali al-amr) têm legitimidade para governar e para formular mais detalhadamente o direito, desde que seus editos não imponham a fiéis muçulmanos a obrigação de praticar atos que a sharī'a repute proibidos ou de abster-se do cumprimento de deveres que ela considere obrigatórios. Além disso, não podem causar danos à sociedade nem impedir a consecução dos objetivos da sharì'a. Sob essa perspectiva, a sharì'a, tal como os ulemás interpretavam-na, constituiria um limite externo ao poder legislativo do Estado e do governante (LOMBARDI; BROWN, 2006, p. 404-405), semelhante ao que se via na tradição jurídica europeia medieval: "Na fusão sacral entre facticidade e validade se enraíza, por exemplo, a hierarquia de leis, da tradição jurídica europeia, segundo a qual o direito estabelecido pelo governante permanece subordinado ao direito natural cristão, administrado eclesiasticamente" (HABERMAS, 2003, p. 45).

Portanto, se por um lado o Islã contém princípios de organização social e política, por outro não se pode dizer que eles tenham se aplicado de modo homogêneo ao longo da história nem em todas as comunidades cuja população tenha aderido à religião muçulmana. ${ }^{54}$ Com essa consideração, pode-se encerrar a exposição sobre os elementos caracterizadores do direito islâmico, com a esperança de que se tenham lançado bases adequadas à compreensão do tema principal deste trabalho.

\footnotetext{
${ }^{54}$ De fato, para Ebrahim Afsah, observa-se ao longo da história do mundo islâmico uma transigência em relação a governos hereditários ou imperiais cujas estruturas destoavam do conteúdo doutrinário do direito islâmico e do modelo de organização social do tempo de Maomé: "Esse 'sim histórico' contradisse o 'não dogmático' ao longo do desenvolvimento do direito islâmico, mas a negação persistente de que qualquer acomodação é possível, muito menos aconteceu, continua a ser um obstáculo enorme a uma compreensão melhor da realidade jurídica em todo mundo islâmico" (AFSAH, 2008, p. 281, tradução livre).
} 


\subsection{A evolução constitucional dos países do mundo islâmico}

Maurizio Oliviero reconstrói a história constitucional dos países do mundo islâmico dividindo-a em cinco fases, para fins analíticos. A primeira fase inicia-se com a tentativa de estatização de Muhamad Alī no Egito e termina com a queda do Império Otomano imediatamente após a Primeira Guerra Mundial (OLIVIERO, 2014, p. 600).

Segundo o autor, "O elemento unificante dessa primeira fase histórica foi indubitavelmente o projeto político na base no expansionismo saudita, caracterizado por uma forte inspiração religiosa que encontrava as suas raízes na ideia da recuperação dos valores originais do Islã como resposta à decadência do Império Otomano" (OLIVIERO, 2014, p. 600, tradução livre). Os governantes sauditas aliam-se ao movimento conhecido como "wahabismo", cujo fundador, Muhammad ibn ‘Abd al-Wahhab (1703-1792), "Em 1744, lançou uma campanha de purificação e renovação. Seu objetivo declarado era retornar ao puro e autêntico islã do Fundador, removendo e, onde necessário, destruindo todos os posteriores acréscimos e distorções" (LEWIS, 2004, p. 116).

Na teoria tradicional do Estado na tradição islâmica a que o movimento wahabita propunha retornar, o califa ou sucessor do Profeta é o chefe político da comunidade muçulmana (umma). Sua nomeação tem caráter contratual. Tipicamente, esse contrato estabelece o dever do governante de aplicar a lei divina e de proteger os muçulmanos em contrapartida à obediência e ao apoio popular (EL FADL, 2012, p. 46), como dispõem os versos corânicos a seguir: "Allah manda restituirdes ao seu dono o que vos está confiado; quando julgardes entre as pessoas, fazei-o com equidade. [...] Ó crentes, obedecei a Allah, ao Mensageiro e às autoridades, dentre vós!” (Corão, 4:58-59). Na teoria clássica, o contrato é celebrado entre o califa e aqueles que têm capacidade de escolhê-lo (ahl al-hāllwa-laqd), os quais dão àquele um compromisso de fidelidade (bay'a). Em uma crítica a Azizah Y. al- Hibri, que traduz bay'a como eleição e atribui a esse termo o sentido de um processo político por meio do qual a vontade do povo pode se expressar (AL-HIBRI, 1998, p. 503 e 511), ${ }^{55}$ Emon mostra que o tratamento jurídico sobre o bay'a tem nuances:

\footnotetext{
${ }^{55}$ Essa autora compara a chamada "Constituição de Medina" - um acordo que o profeta Maomé teria celebrado com as tribos da península arábica, conforme o qual ele seria o árbitro final das disputas - com a constituição dos Estados Unidos e atribui àquela os antecedentes mais remotos do federalismo, que teria contribuído para uma relação de cooperação entre muçulmanos, judeus e pagãos. A "Constituição de Medina" tem servido como lugarcomum para discursos sobre liberdade religiosa no Islã. Historiadores muçulmanos e a maior parte dos autores do direito islâmico tomam o documento como certo, mas existem divergências sobre sua autenticidade como fato histórico, cf. EMON (2001).
} 


\begin{abstract}
“Apologistas muçulmanos comumente igualam a noção de bay'a com o princípio democrático do voto popular a fim de sugerir que o Islã não só é consistente com princípios democráticos, mas de fato os expôs antes que a democracia emergisse no Ocidente. Tratamentos históricos e jurídicos do bay'a na tradição islâmica, contudo, oferecem um retrato nuançado. Por exemplo, com a morte do Profeta, o primeiro califa Abū Bakr foi selecionado por um grupo de pessoas, o ahl al-hällwa-laqd. Eles deram a ele seu bay'a e assim ele se tornou o califa. Em contraste, o segundo califa, Umar ibn alKhattāb, foi nomeado por Abū Bakr sozinho, sem consulta com um comitê. O terceiro califa, Uthmān ibn Affān, foi selecionado por um comitê de indivíduos nomeados por Umar. E, finalmente, sob as dinastias omíada e abássida, o califado tornou-se uma posição hereditária. A partir destes exemplos, a natureza do bay'a é obscura." (EMON, 2001, p 125-126, tradução livre)
\end{abstract}

Em função dessas nuances históricas, Maurizio Oliviero aponta que as modalidades de aquisição do califado são três: a eleição por parte do ahl al-hāllwa-laqd ${ }^{56} \mathrm{com}$ quem o califa celebra o contrato de imamato; a designação do sucessor por parte do predecessor; e, por fim, a ocupação ou usurpação do poder, que a doutrina islâmica reconhece como modo de aquisição da posição de califa por força do princípio de que a tirania é preferível à anarquia (OLIVIERO, 2014, p. 601). Além disso, “Os poderes do califa podem ser delegados em favor de um ministro ou em benefício de emires gerais, para o governo das regiões e das cidades. No que diz respeito, em particular, à administração da justiça, o califa delega a funcionários especiais, que assumem a denominação de $q \bar{a} d \vec{\imath}$ ' (OLIVIERO, 2014, p. 601-602, tradução livre). Os califas não têm poderes legislativos, porque a determinação de regras jurídicas compete aos estudiosos a partir das fontes sagradas, como visto no item anterior. ${ }^{57}$

A segunda fase é aquela da imposição dos modelos constitucionais europeus e da afirmação do conceito de nação. Ela tem início com a Conferência de San Remo, no ano 1920, quando os países do Oriente Médio foram divididos e colocados sob o protetorado da França ou da Grã-Bretanha. Termina em 1948, quando se evidencia a crise dos regimes políticos que

\footnotetext{
${ }^{56}$ Para Oliviero, ahl al-hāllwa-laqd são "aqueles representantes da umma que, sendo irrepreensíveis, são também capazes de reconhecer em um indivíduo a essência dos requisitos necessários para ser califa e, por conseguinte, são também capazes de escolher o candidato mais idôneo estipulando com ele o contrato de imamato" (OLIVIERO, 2014, p. 601, tradução livre), mas essa expressão refere-se a um grupo que varia conforme o contexto, designando, geralmente, pessoas notáveis em conjunto com estudiosos religiosos e funcionários públicos (EMON, 2001, p. 126).

${ }^{57}$ Embora Maurizio Oliviero não aborde esse aspecto no artigo em que reconstrói a história constitucional do mundo islâmico, a despeito da aliança com o movimento wahabita e da imposição de uma versão fundamentalista do direito islâmico (exceto no campo do direito comercial, como o professor Mohamed A. Arafa esclareceu no curso "Islamic Law and Comparative Middle Eastern Legal and Political Studies"), quando se observa a ordem constitucional para além da teoria clássica, a característica mais marcante da Arábia Saudita é a riqueza do petróleo, que permite a ela obter renda sem taxação, o que contribui para que os governantes possam ignorar a opinião pública. Sobre o tema, cf., por exemplo, LEWIS (2004, p. 124)
} 
estavam sob a tutela europeia. Nessa fase, o nacionalismo local nasce como reação à colonização estrangeira e marca os movimentos pela independência (OLIVIERO, 2014, p. 602).

Oliviero explica que graus diferentes de dominação colonial determinaram três contextos institucionais. O primeiro grupo, que inclui o Egito, o Iraque e a Arábia Saudita, obteve a independência pouco depois da Primeira Guerra Mundial e adotou uma fisionomia estatal que variou pouco até hoje. O segundo compreende os países da Grande Síria tradicional, fracionada em entidades territoriais que deram origem ao Líbano, à Síria, à Jordânia e à Palestina atuais, todos colocados sob o esquema de protetorado da Liga das Nações. Por fim, os países do Magreb foram submetidos ao mandato francês, com exceção da Líbia, que se tornou colônia italiana (OLIVIERO, 2014, p. 603).

Com exceção da Arábia Saudita, os países do primeiro e do segundo bloco condicionaram-se aos modelos constitucionais europeus, seja por meio da imposição pela potência colonial estrangeira ou por meio da importação pelas elites locais que desejavam se manter no poder. Os países sob influência ou controle britânico constituíram monarquias parlamentares, enquanto aqueles da área de influência francesa seguiram o modelo republicano.

No Egito, por exemplo, o sultão assumiu o título de rei e convocou um comitê formado por líderes políticos e juristas para editar um texto constitucional. No Iraque, oficiais britânicos em Bagdá redigiram o texto da constituição e submeteram ao departamento colonial em Londres e ao rei Faysal Houssein, que eles próprios haviam trazido do Hejaz para assumir o trono. Os britânicos partiram do modelo otomano (por sua vez, semelhante à constituição belga) e também do tex to egípcio que estava em elaboração. Entretanto, a autoridade final sobre o Estado não pertencia ao rei ou ao parlamento, porque o tratado que estabeleceu o mandato britânico sobre o Iraque manteve-se acima das normas constitucionais. A Jordânia seguiu mais ou menos o mesmo percurso que o Iraque, com oficiais britânicos elaborando um texto constitucional monárquico e um tratado (BROWN, 2002, p. 36-50; OLIVIERO, 2014, p. 603).

No lado francês, a Síria elegeu uma assembleia constituinte que escreveu um texto constitucional republicano, que previa o exercício do poder executivo por um presidente. Entretanto, a França não o aceitou e depois reeditou com duas alterações relacionadas à delimitação territorial do país e à rejeição do Estado unitário, em 1930. No Líbano, a França elaborou um projeto de constituição parecido com o da Síria, e os dois países perfilharam caminhos semelhantes até a independência. Uma característica importante da constituição libanesa é a distribuição dos assentos no parlamento de modo proporcional em relação aos grupos étnico-religiosos existentes no país (cristãos maronitas, muçulmanos sunitas e xiitas), um padrão que se manteve até 1958 (BROWN, 2002, p. 65-72). 
Em vez de produzir a "ocidentalização" que os países colonizadores esperavam, a presença europeia no mundo árabo-islâmico deu origem ao nacionalismo local. Exemplificativamente, no Egito, o movimento nacionalista institucionalizou-se no partido Wadf, que, "se por um lado lutava pelo reconhecimento de uma independência efetiva, por outro propunha a realização de um modelo de Estado modernista, segundo os exemplos oferecidos pelo Ocidente" (OLIVIERO, 2003, p. 18, tradução livre). Além disso, os grupos dominantes "não tiveram a força econômica nem a capacidade política de transformar e modernizar efetivamente seus países" (OLIVIERO, 2014, p. 603, tradução livre). Para Oliviero, a aproximação entre os componentes nacionalistas e potências opostas àquelas que estavam em seu país ou entre aqueles e movimentos fundamentalistas islâmicos "favoreceu o desenvolvimento de relações estratégicas entre alguns movimentos políticos árabes com os regimes fascista e nazista e o nascimento de partidos importantes de inspiração fundamentalista islâmica de caráter integralista" (OLIVIERO, 2014, p. 604, tradução livre).

Durante essa fase, alguns movimentos começaram a construir a base da luta política pela independência nacional a partir da ideia da unidade árabe. O projeto de reunificação árabe encontrou apoio também nos âmbitos religiosos islâmicos, "os quais, diante da crise que as instituições de moldes liberais propostas pelos nacionalistas encontravam na sociedade árabe, reivindicavam a originalidade do modelo cultural e institucional islâmico e rejeitavam as soluções importadas do Ocidente" (OLIVIERO, 2014, p. 604). Os nacionalismos locais cedem lugar ao ideal pan-arabista a partir da insurreição palestina de 1936, que desencadeou uma onda de solidariedades entre os países árabes. Além disso, na primeira metade da década de 1940, fundou-se o partido al-Baas (ou $B a^{\prime} t h$ ) na Síria, de onde se espalhou para outros países árabes. Depois de conquistar o poder, na Síria e no Iraque, “o Baas afirmou-se como uma das forças políticas e progressistas mais importantes no mundo árabe e desempenhou um papel de primeiro plano [...] na luta contra o colonialismo e em favor dos direitos do povo palestino" (OLIVIERO, 2003, p. 19, tradução livre). O mapa abaixo indica as datas de independência dos países do Oriente Médio e do Norte da África (Figura 2): 
Figura 2. Datas de Independência ${ }^{58}$

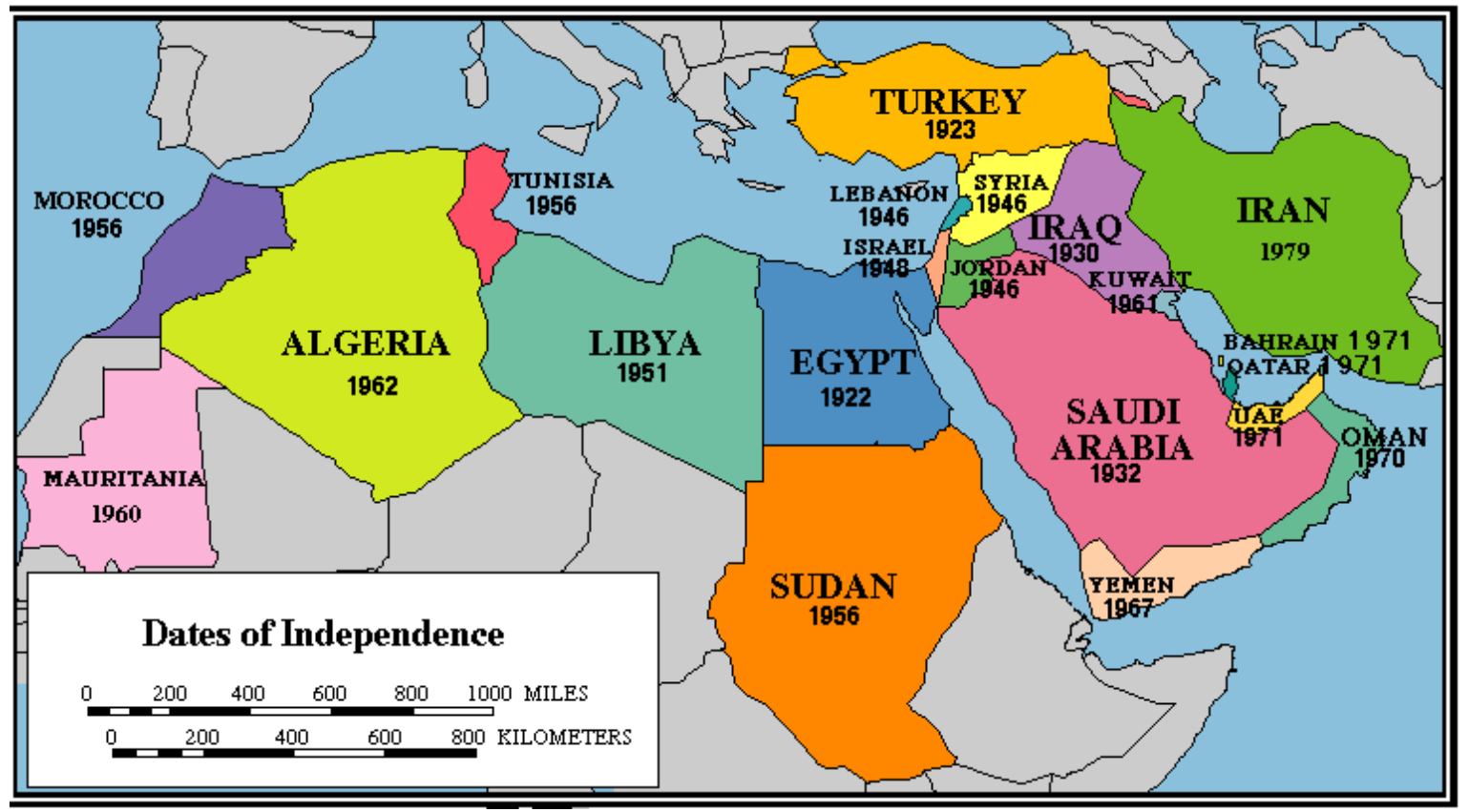

A terceira fase dessa reconstrução histórica caracteriza-se pela tentativa de unificação dos países árabes promovida por Gamal Abd al-Nasser. O suporte político do projeto de Nasser é a União Socialista Árabe, o partido único por meio do qual se pretendia exercer o poder. Nessa época, “a ineficácia dos sistemas parlamentares corruptos e a ausência de forças políticas organizadas [...] transformaram os exércitos, e de modo mais geral as burocracias militares, em um elemento de rompimento com o período anterior" (OLIVIERO, 2014, p. 605, tradução livre). As forças armadas eram a única instituição estatal estável no mundo árabe e, por isso, assumiram o protagonismo no exercício do poder político em um ambiente marcado pela instabilidade. Por meio de golpes de Estado, os militares colocavam-se como referência institucional mais importante e defendiam a unidade árabe. Eles adotam a república como forma de Estado e declaram o pertencimento à nação árabe nos textos constitucionais, como se observa a partir da constituição síria de 1950, na constituição egípcia de 1956 e na constituição iraquiana de 1958 (OLIVIERO, 2014, p. 605).

No texto constitucional sírio de 1950 afirma-se pela primeira vez o papel da sharī'a como a fonte principal do direito. Porém, como alerta Maurizio Oliviero, “isso não impediu que em quase todos os regimes se impusessem ordenamentos com um caráter substancialmente laico, na medida em que, pelo menos nessa fase, as referências ao Islã deviam ser

\footnotetext{
${ }^{58}$ Mapa em domínio público. Disponível em: http://www.dartmouth.edu/ gov46/dates-independence.gif. Acesso: 08 ago. 2016.
} 
compreendidas como reconhecimentos formais das tradições culturais comuns da nação árabe" (OLIVIERO, 2014, p. 606, tradução livre). Esse ideal pan-arabista, que lembrava a utopia do califado até o início do Século XX, entrou em crise com a derrota militar dos países árabes na guerra contra Israel, em 1967.

A quarta fase teve início nesse contexto. Nela, há um retorno aos nacionalismos locais e ao fundamentalismo islâmico. Houve um deslocamento da liderança geopolítica do Egito para a Arábia Saudita. O sucessor de Nasser, Anwar al-Sadat, promove uma abertura política para a oposição islamita, que havia sido violentamente suprimida no período anterior. Nesse sentido, Sadat aceita uma emenda constitucional à carta de 1971 que modificou a redação do artigo $2^{\circ}$ para dispor que a sharī’a é "a" fonte principal da legislação egípcia, em vez de "uma" fonte, como dizia anteriormente. ${ }^{59}$ Nessa época, outros elementos centrífugos aparecem no interior de cada Estado-nação, em especial sob a forma de particularismos étnicos, linguísticos ou religiosos. No Líbano, mudanças demográficas expuseram a fragilidade do pacto constitucional de distribuição do poder entre cristãos maronitas, muçulmanos sunitas e xiitas, levando a uma guerra civil a partir de 1975, que ameaçava dividir o país em Estados confessionais menores (OLIVIERO, 2014, p. 607-608).

A quinta e última fase encontra seu marco inicial na Revolução Iraniana de 1979, que tem um significado profundo também para o mundo sunita. Ela mostra a possibilidade da instauração de um Estado islâmico e constitui um ponto de referência ideológico para os movimentos fundamentalistas islâmicos. Sob o ponto de vista institucional, exibe novidades como o Conselho dos Guardiões, formado por seis juristas religiosos, com a função específica de declarar a nulidade das leis existentes e das propostas legislativas contrárias aos padrões islâmicos que estão na base ideológica da revolução. A teoria do mandato ou da autoridade do jurista (velāyat-e faqīh) visa a justificar o poder do Líder Supremo como um monarca teocrático que governa em nome de Deus (ARJOMAND, 2012, p. 158-159).

A Revolução Iraniana provocou duas reações distintas nos países de maioria sunita: no Marrocos e na Jordânia, por exemplo, as monarquias constitucionais tentaram reforçar sua legitimidade islâmica; no Egito, na Tunísia, na Argélia e na Síria, regimes autoritários afirmaram-se principalmente por meio de textos constitucionais que foram suspensos imediatamente após sua edição em razão da suposta necessidade de conter a islamização do

\footnotetext{
${ }^{59}$ Anwar al-Sadat não foi o único chefe de Estado militar que adotou medidas de islamização da ordem jurídica para apaziguar a oposição islamita e para tentar obter ganhos em termos de legitimação. Por exemplo, no Paquistão, após o golpe militar que instalou o General Muhammad Ziā'-ul-haq no poder em 1977, criaram-se mecanismos institucionais de islamização da ordem jurídica (LAU, 2012, p. 196). Na Líbia, Muammar Kadafi criou e financiou a Sociedade do Chamado Islâmico, com propósito missionário em todo o mundo (WATT, 2013, p. 58).
} 
Estado e o fundamentalismo islâmico. Assim, Hosni Mubarak, Presidente do Egito, declarou estado de emergência no ano de 1981, conferindo a si mesmo poderes especiais. Também na Argélia, declarou-se estado de emergência em 1992. A característica como a todos esses países é o papel preponderante dos militares no Estado: "Os exércitos transformaram-se em instrumentos de estabilidade dos governos também por meio da justificação de representarem uma garantia contra os riscos eventuais de radicalização religiosa no interior dos vários países" (OLIVIERO, 2014, p. 610, tradução livre).

Apesar disso, a maior parte das constituições vigentes são caracterizadas por algum princípio fortemente confessional. Exemplificativamente, os textos constitucionais do Marrocos (artigo $3^{\circ}$ ), da Argélia (art. $2^{\circ}$ ), da Tunísia (art. $1^{\circ}$ ), da Malásia (art. $3^{\circ}$ ) declaram que o Islã é a religião oficial do Estado; os do Egito (art. $2^{\circ}$ ), do Irã (art. $2^{\circ}$ ), do Iraque (art. $2^{\circ}$, caput) estabelecem a sharī'a como uma ou como a fonte principal do direito; as constituições recentes do Afeganistão (art. $3^{\circ}$ ) e do Iraque (art. $2^{\circ}$, A) preveem o que em inglês se chama repugnancy clause, de acordo com a qual as leis contrárias às determinações do Islã devem ser consideradas inválidas, assim como a do Paquistão (art. 227). ${ }^{60}$

Finalmente, cabe assinalar que o objetivo desta reconstrução breve da história constitucional dos países do mundo árabo-islâmico não é prover uma exposição completa sobre o desenvolvimento do direito constitucional em cada um deles, o que seria incompatível com o escopo deste trabalho, mas oferecer informações suficientes para uma aproximação em relação ao tema principal, apontando traços definidores de cada uma das fases históricas - cuja divisão só faz sentido para fins analíticos. Em especial, contribui para indicar alguns problemas relacionados à recepção incompleta de instituições modernas nos países do mundo islâmico, tema que será retomado no item 3.2 deste trabalho.

\subsection{Direito islâmico e liberdade religiosa: os contornos de um problema constitucional}

Historicamente, a expansão do califado não se deu apenas por meio de conquistas militares, mas também por meio de contratos com comunidades que não aderiram à religião. Súditos não-muçulmanos gozavam do status de minoria protegida (dhimmī), de acordo com o qual obtinham proteção em troca do pagamento de um tributo especial. Nos séculos iniciais, esse acordo era vantajoso, não só porque possibilitava o convívio razoavelmente pacífico com os muçulmanos, como também porque a cobrança era inferior àquela que os Impérios Bizantino

\footnotetext{
${ }^{60}$ Em contrapartida, a Turquia e os países que fizeram parte da União Soviética, tais como Cazaquistão,
} Turcomenistão e Azerbaijão, não têm dispositivos constitucionais de cunho confessional. 
e Sassânida faziam nos territórios vizinhos. ${ }^{61}$ No califado abássida, os chefes das comunidades cristãs desempenhavam funções públicas: "supervisionavam as escolas e os serviços sociais, e tentavam prevenir desvios de doutrina ou da prática litúrgica. Também supervisionavam os tribunais onde os juízes ministravam a lei em casos civis envolvendo dois membros da comunidade, ou resolviam desacordos" (HOURANI, 2006, p. 166). No Império Otomano, judeus e cristãos ocuparam cargos importantes na administração central. ${ }^{62}$

Para autores do direito islâmico, os contratos que garantiam a proteção de minorias evidenciam o compromisso do Islã com a liberdade religiosa. Soma-se a eles o verso corânico segundo o qual "Não há imposição quanto à religião" (Corão, 2:256), interpretado por muitos muçulmanos como a prova escritural de que o Islã é uma religião de tolerância. Além disso, outros versos reiterariam a previsão normativa da liberdade religiosa na estrutura do direito islâmico clássico: "Vós tendes a vossa religião e eu tenho a minha" (Corão, 109:6); "Porém, se teu Senhor tivesse querido, aqueles que estão na terra teriam acreditado unanimemente. Poderias (ó Mohammad) compelir os humanos a que fossem crentes?" (Corão, 10:99). Conforme essa interpretação, "Liberdade de crença (note o modo de falar ocidental) é fundamental para os direitos humanos, e o Islã foi o primeiro a proclamar esse valor" (COOK, 2000, p. 35, tradução livre).

Porém, a partir do Século XIX, com a codificação da doutrina da escola hanifita no Império Otomano, o direito islâmico passou a aplicar-se pela primeira vez a não-muçulmanos. Após a Primeira Guerra Mundial, Mustafa Kemal Atatürk, líder do movimento nacionalista na Turquia e presidente do país depois da fundação da república, promoveu uma agenda de secularização da sociedade, ${ }^{63}$ a fim de forjar uma identidade nacional especificamente turca. Com a independência e a partir da segunda fase da história constitucional indicada no tópico anterior, "veio a necessidade de desenvolver políticas governamentais e códigos legais assim como identidades nacionais para as nações recém-criadas. Restrições sociais e governamentais

\footnotetext{
${ }^{61}$ Convém anotar que o status de minoria protegia aplicava-se somente aos "povos do livro", isto é, a judeus e cristãos, cujos profetas o Islã também reconhece (cf. nota de rodapé n. 49).

${ }^{62}$ Isso não significa que não tenha havido momentos de perseguição religiosa: "Nos longos séculos de domínio muçulmano houve alguns períodos de perseguição constante a não-muçulmanos por governantes muçulmanos: por exemplo, o reino do califa fatímida al-Hakim (996-1021) no Egito, o dos almôadas no Magreb e o de alguns governantes mongóis no Irã e Iraque, depois de se converterem ao Islã. Essa perseguição não foi instigada nem justificada pelos porta-vozes do Islã sunita, porém; os homens de cultura religiosa, os ulemás, tratavam de assegurar que os não-muçulmanos não infringissem as leis que regulavam seu status, mas dentro desses limites mantinham a proteção que a charia concedia a eles. A pressão sobre judeus e cristãos pode ter vindo basicamente das massas urbanas, sobretudo em tempos de guerra ou dificuldade econômica, quando a hostilidade se voltava contra os funcionários não muçulmanos do governante. Nesses momentos, o governante podia reagir aplicando a lei com severidade, ou demitindo seus funcionários não muçulmanos, mas não por muito tempo. Tais crises ocorreram várias vezes durante o período de governo mameluco no Egito e na Síria" (HOURANI, 2006, p. 165). ${ }^{63} \mathrm{Cf}$. item 2.3, infra.
} 
à religião podem então ter sido vistas como uma parte estratégica do processo de construção nacional [nation-building]" (GRIM; FINKE, 2011, p. 173, tradução livre). Posteriormente, depois desse período, o Islã emerge como parte das identidades nacionais e da busca por autenticidade na organização social. Esse pano de fundo histórico ajuda a compreender restrições à manifestação da religião e casos de perseguição religiosa no mundo islâmico atual.

Dados coletados por Grim e Finke (2011, p. 32) indicam que quinze dos vinte países que aderem em alguma medida à sharī'a e têm população superior a dois milhões de habitantes contam com a previsão constitucional do direito à liberdade religiosa. Isso corresponde a aproximadamente $67 \%$ dos países, o que está abaixo do percentual no mundo como um todo. Porém, catorze desses quinze países têm quatro ou mais leis infraconstitucionais que restringem a prática religiosa de algum modo. Os gráficos abaixo ilustram o modo como a constituição e as leis interferem na liberdade religiosa em uma dimensão comparativa: ${ }^{64}$

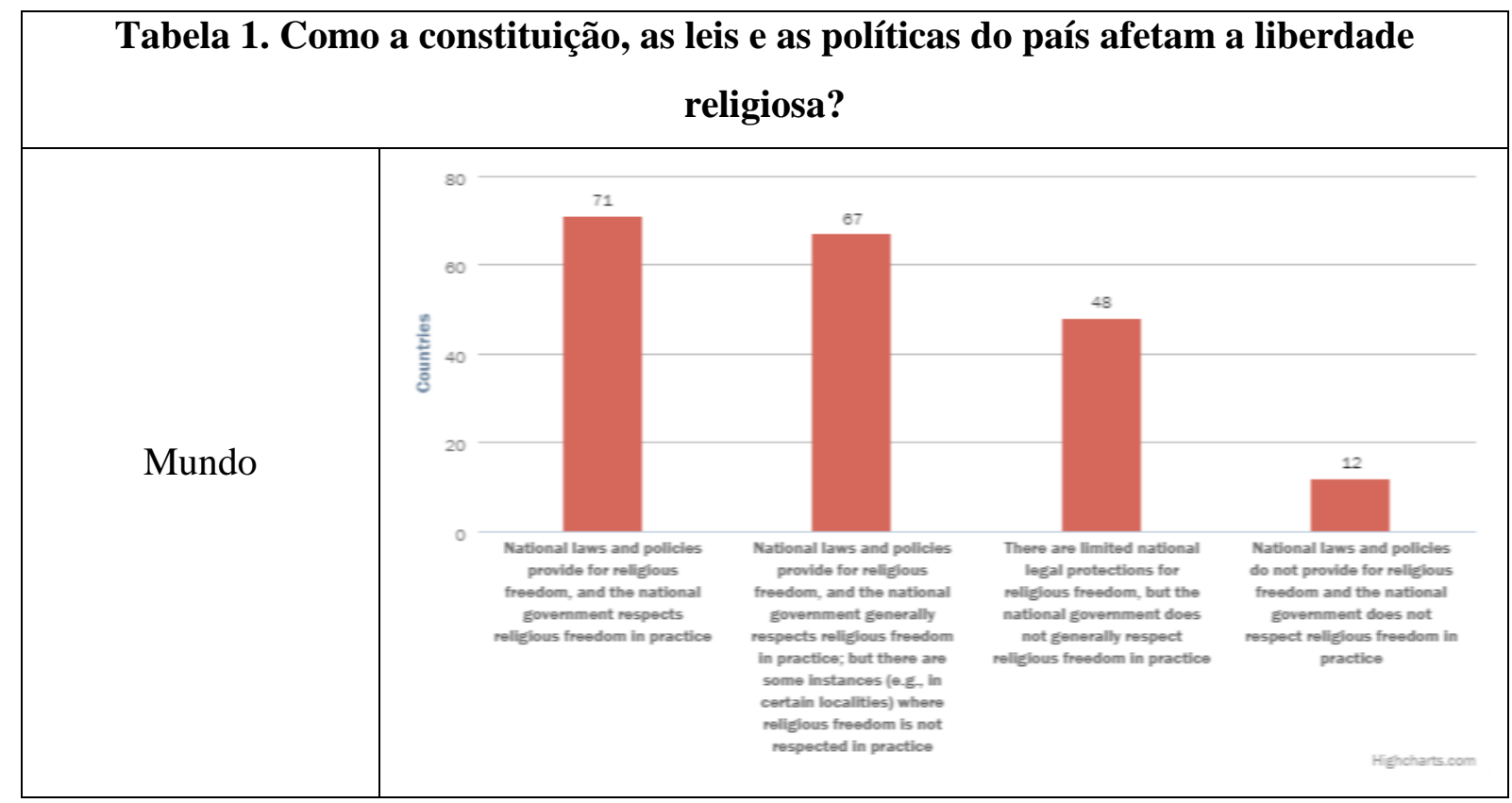

\footnotetext{
${ }^{64}$ Os gráficos foram obtidos a partir de uma ferramenta disponível na página do Pew Research Center na Internet que possibilita a exploração dos dados coletados por essa instituição. Eles estão disponíveis nos endereços eletrônicos a seguir, respectivamente: http://www.globalreligiousfutures.org/downloadable/15341.png; http://www.globalreligiousfutures.org/downloadable/15340.png. Acesso: 08 ago. 2016.
} 


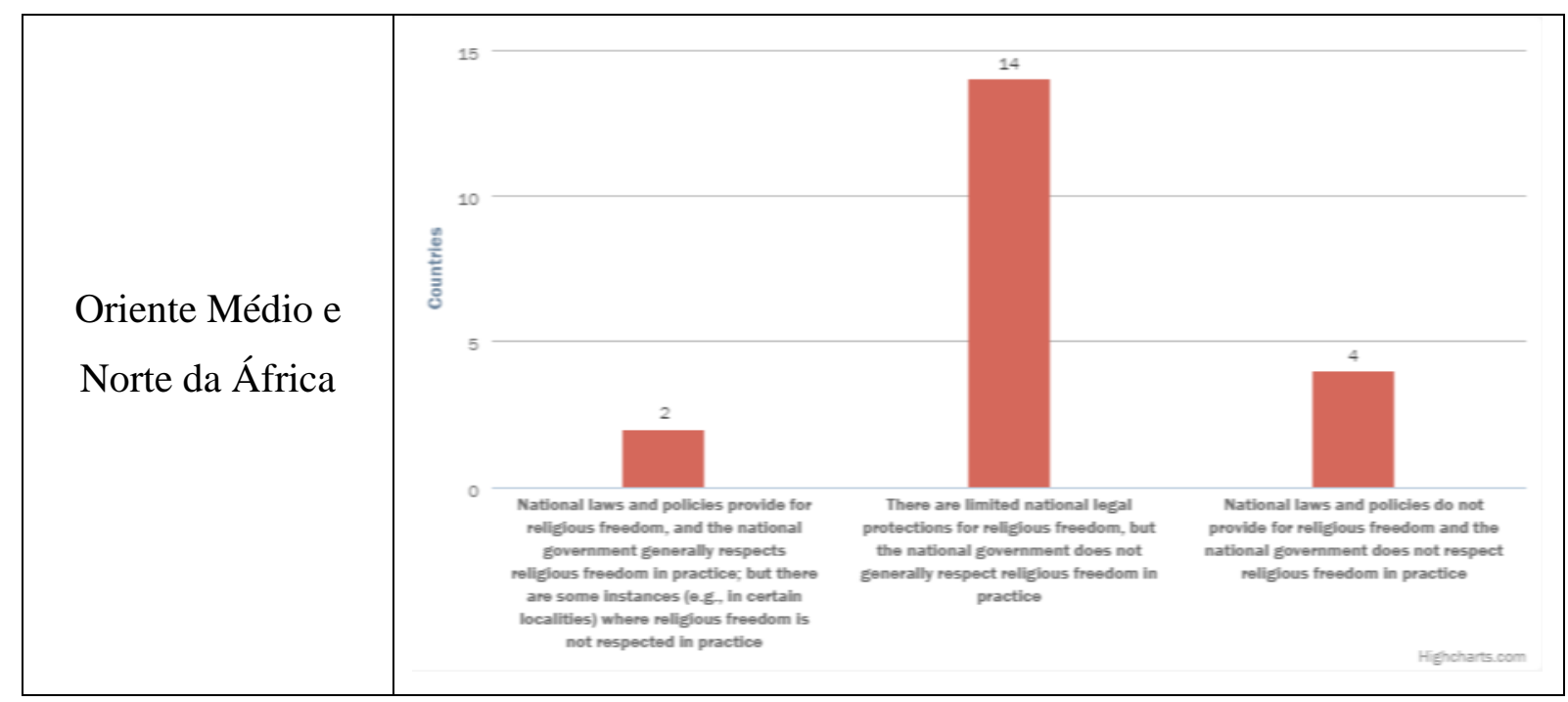

Outro dado importante é o de que a maior parte das vítimas de perseguição religiosa nos países de maioria muçulmana são seitas ou grupos minoritários de pessoas muçulmanas ${ }^{65}$ (GRIM; FINKE, 2011, p. 185). Para explicar o motivo por que isso acontece, deve-se lembrar que a tradição jurídica islâmica reconhece uma pluralidade de escolas doutrinárias e acomoda perspectivas distintas sobre o que a sharī'a exige. Contudo, a codificação do direito a partir do Século XIX e a afirmação do modelo de Estado-nação perturbam a possibilidade de convivência entre interpretações variadas do direito islâmico e dão lugar a disputas entre os próprios muçulmanos sobre a extensão da aderência à ordem religiosa e à competição entre as versões possíveis do Islã para tornarem-se a versão oficial no país.

Para o governo ou para o Estado, o controle sobre o exercício da religião pretende diminuir o risco de oposição religiosa ou de desestabilização social. Esse fator aparece de modo mais incisivo nos contextos em que as instituições estatais não gozam de força suficiente para intermediar os conflitos, como é o caso da maior parte dos países do mundo islâmico. Entretanto, em vez de tentar controlar as religiões, o governo pode aliar-se àquela dominante, o que pode se dar com o reconhecimento de efeitos normativos aos preceitos dessa religião ou, no caso específico do mundo islâmico, com a imposição da sharī'a. Para a religião dominante, em contrapartida, a restrição à liberdade religiosa serve para afastar ameaças à sua posição privilegiada e a competição religiosa. De acordo com Grim e Finke, "quanto mais forte for a aliança entre religião e Estado, mais provavelmente os poderes estatais serão utilizados para perseguir competidores religiosos" (GRIM; FINKE, 2011).

\footnotetext{
${ }^{65}$ É o caso da comunidade Ahmadi no Paquistão, que será objeto de discussão no item 2.1, infra. Faz-se necessário esclarecer que não só divisões religiosas como também fatores étnicos e linguísticos contribuem para a tensão entre grupos diferentes nos países de maioria muçulmana.
} 
Essas considerações contrariam a perspectiva religiosa dos autores que buscam justificar a imposição da sharī'a no âmbito das ordens jurídicas contemporâneas. Exemplificativamente, Khaled Abou El Fadl aponta quatro razões por que entende que o secularismo seria inaceitável:

\begin{abstract}
"Propor secularismo como uma solução a fim de evitar a hegemonia da sharī'a e a possibilidade de abuso do poder é inaceitável. Há várias razões para isso: um, considerando a escolha retórica entre a fidelidade à sharî' $a$ e a fidelidade ao constitucionalismo, compreensivelmente a maioria dos muçulmanos tomará a decisão igualmente retórica de aliar-se à sharī'a. Dois, o secularismo tornou-se um construto social impraticável e inútil. No mundo muçulmano, secularismo é normalmente associado com o que é descrito como invasão intelectual ocidental, tanto no período de colonialismo como no póscolonialismo. Além disso, secularismo veio a simbolizar a crença equivocada na probidade do racionalismo e um sentido de hostilidade à religião como uma fonte de orientação na esfera pública. Três, além da questão do simbolismo, como visto anteriormente, existe uma variação considerável na prática do secularismo. É totalmente obscuro até que ponto a prática do secularismo requer a separação de igreja e Estado, especialmente à luz do fato de que não há igreja institucionalizada no Islã. Colocando de outro modo, até que ponto a prática do secularismo impõe a exclusão da religião do domínio público, incluindo a exclusão da religião como uma fonte do direito? Finalmente, na medida em que o paradigma secular repousa sobre uma crença no valor de orientação da razão como um meio de atingir a satisfação utilitarista ou a justiça, ele se funda em uma convicção que não é empírica nem moralmente verificável. Uma pessoa poderia plausivelmente acreditar que a religião é um meio igualmente válido de conhecer ou descobrir os meios para a felicidade ou justiça" (EL FADL, 2012, p. 56, tradução livre).
\end{abstract}

Então, a disputa interna quanto ao grau de influência que a sharī'a deve exercer sobre as ordens jurídicas contemporâneas e a perspectiva religiosa que corporifica a busca por formas alternativas de regulação da ação social que se contraponham ao modelo secular ocidental confluem para limitar a eficácia da liberdade religiosa nos países do mundo islâmico.

Todavia, o risco da demanda de que o Estado imponha a sharī'a em seu âmbito de jurisdição territorial é o de sobrepor o código da política ao código da religião e impedir a reprodução desta como um sistema social da sociedade abarcante. Como o estudioso muçulmano sudanês Abdullahi Ahmed An-Na'im assinala precisamente, "tudo o que o Estado edita e impõe deixa de ser religioso pelo próprio fato de que o Estado o impõe coercitivamente" (AN-NA'IM, 2011, p. 1252, tradução livre).

Com isso, espera-se ter provido uma introdução adequada para o próximo capítulo, em que se apresentarão casos concretos relacionados ao problema da liberdade religiosa nos países do mundo islâmico. 


\section{INTERAÇÕES ENTRE O DIREITO ISLÂMICO E OUTRAS ORDENS JURÍDICAS}

No capítulo anterior, apresentou-se o direito islâmico como ordem jurídica, destacando alguns dos elementos caracterizadores de sua estrutura e a maneira como os textos constitucionais dos países do mundo islâmico incorporam-no às respectivas ordens estatais. Neste capítulo, expor-se-ão casos judiciais sobre liberdade religiosa em que a conversação ou o confronto entre o direito islâmico e outras ordens jurídicas da sociedade mundial revelaramse no processo de concretização da norma jurídica. Por ora, a intenção é preponderantemente expositiva, deixando a avaliação sobre essas interações para uma seção posterior.

\subsection{Livre exercício da religião: Zaheeruddin et al. v. State, o caso dos Ahmadis (Paquistão) ${ }^{66}$}

Os Ahmadis são pessoas religiosas que se identificam como integrantes da comunidade muçulmana e como seguidores do Islã (SIDDIQ, 1995, p. 278). O grupo surgiu nas décadas finais do Século XIX, originariamente no vilarejo de Qadian, na região de Punjab, localizada no norte do subcontinente indiano e compreendida atualmente pelo norte da Índia e pelo leste do Paquistão, por meio da pregação e dos escritos de Mirza Ghulam Ahmad (18361908), que se autoproclamou um renovador da religião muçulmana e também um profeta. Depois, alegou igualmente ser o messias aguardado pelos cristãos e o avatar de Krishna esperado por hinduístas, o que, de acordo com Montgomery Watt, "é obviamente uma resposta à situação de pluralismo religioso existente na Índia, e é contrastante em relação ao silêncio da maioria dos muçulmanos sobre outras religiões” (WATT, 2013, p. 59, tradução livre).

Em comparação à crença e aos ritos seguidos pela maior parte dos muçulmanos, não existem diferenças relevantes. Os muçulmanos Ahmadis adotam o Corão como escritura sagrada e declaram sua fé recitando a kalima tayyab (Palavra de Pureza), segundo a qual "só há um Deus, e Maomé é o Seu Profeta”. Suas preces seguem as obrigações rituais de todo muçulmano, incluindo a posição direcionada a Meca e o azan, ${ }^{67}$ que é o chamado islâmico para

\footnotetext{
${ }^{66}$ Embora a página da Suprema Corte do Paquistão na Internet disponibilize o texto de algumas de suas decisões, a pesquisa não identificou, entre esses documentos, a decisão do caso Zaheeruddin $v$. State, que é objeto deste tópico. Em razão disso, utilizou-se a reprodução disponível no endereço eletrônico http://thepersecution.org/archive/judgement/index.html (acessado pela última vez em 29 de abril de 2016). Tratando-se de fonte não-oficial, confrontou-se o texto com aquele disponível no site http://www.irshad.org/exposed/legal/pkcort93.php (acessado pela última vez na mesma data) e também com as transcrições parciais existentes nos artigos acadêmicos sobre o tema que integram a bibliografia deste trabalho. Esse cuidado permitiu inferir a fidedignidade da reprodução do texto consultado, que não tem paginação.

${ }^{67}$ Outra transliteração do termo utilizada pela literatura em língua inglesa é "adhan".
} 
a oração (SIDDIQ, 1995, p. 279). Apesar disso, os ulemás denunciaram a pregação de Ghulam Ahmad como herética desde o início, em 1891 (WATT, 2013, p. 59).

A diferença entre sunitas e Ahmadis concentra-se na questão do finamento ou cessação do profetismo. O Corão descreve Maomé como “o derradeiro dos profetas" (khātam na-nabiyyīn). ${ }^{68} \mathrm{O}$ cisma entre sunitas e Ahmadis diz respeito à compreensão dessa expressão. Enquanto aqueles afirmam que Maomé é o último dos profetas em um sentido cronológico isto é, de que depois dele não haverá qualquer outro -, os Ahmadis enfatizam seu status espiritual, sustentando que o caráter final do profetismo de Maomé significa que ele é o mais perfeito dos profetas, assim como o último a trazer consigo a lei divina, o que encontraria suporte em outros versos do Corão ${ }^{69}$ (SIDDIQ, 1995, p. 280-281). A crença desta comunidade varia entre a posição de que Mirza Ghulam Ahmad foi um profeta ou o espelho de um profeta e a visão de que ele não foi um profeta, mas um renovador. Essa questão divide os Ahmadis em dois grupos: o primeiro, que é majoritário e conhecido popularmente como "Quadianis" (em referência à cidade de Mirza Ghulam Ahmad), acredita que ele foi um profeta; o segundo, conhecido como “Lahoris", considera-o um renovador (MAHMUD, 1995, p. 43).

Nesse contexto, desde momento anterior à independência do Paquistão, os ulemás opõem-se à comunidade Ahmadi, porque consideram a qualidade profética que ela atribui a Mirza Ghulam Ahmad ofensiva à crença sunita no finamento do profetismo de Maomé. Em 1952, eles se reuniram em uma convenção que exigiu a declaração de que os Ahmadis não são muçulmanos e a demissão de Zafrulla Khan (1893-1985), um Ahmadi que à época ocupava o cargo de Ministro das Relações Exteriores. ${ }^{70} \mathrm{O}$ governo central impôs uma lei marcial à província de Lahore e instalou uma comissão de inquérito, cujo relatório assinalou responsabilidade pelo tumulto a grupos religiosos muçulmanos e a algumas facções da Liga Muçulmana Paquistanesa (MAHMUD, 1995, p. 68). Em 1974, “os ulemás iniciaram uma segunda onda de agitações anti-Ahmadi” (MAHMUD, 1995, p. 72, tradução livre), em que voltaram a exigir a declaração de que os Ahmadis não são muçulmanos e a demissão dos funcionários públicos associados a esse grupo. Em setembro daquele ano, o Parlamento

\footnotetext{
${ }^{68}$ Corão, 33:40: "Em verdade, Mohammad não é o pai de nenhum de vossos homens, mas sim o Mensageiro de Allah e o derradeiro dos profetas; sabei que Allah é Onisciente."

Na literatura em língua inglesa, a expressão "o derradeiro dos profetas" é traduzida como "the seal of the prophets", o que sugere uma linguagem mais metafórica do que aquela indicada na tradução brasileira do Corão.

69 Corão, 7:35: “Ó filhos de Adão, quando se apresentarem mensageiros, dentre vós, que vos ditarão Meus versículos, aqueles que temerem a Allah e n'Ele confiarem não serão presas do temor, nem se angustiarão.”

${ }^{70}$ Em 1962, Zafrulla Khan foi eleito Presidente da Assembleia-Geral das Nações Unidas e, entre 1970 e 1973 , Presidente da Corte Internacional de Justiça, em Haia (WATT, 2013, p. 59).
} 
promulgou uma emenda constitucional, por meio da qual acrescentou ao art. 260 a definição de "não-muçulmano":

\begin{abstract}
"Uma pessoa que não acredite no finamento absoluto e incondicional do Profetismo de Maomé (Paz esteja com ele), o último dos Profetas, ou que afirme ser um Profeta, em qualquer sentido da palavra ou de qualquer descrição que seja, depois de Maomé (Paz esteja com ele), ou que reconheça tal reivindicador como um profeta ou como um reformador religioso, não é um muçulmano para os propósitos da constituição ou do direito." (MAHMUD, 1995, p. 73, tradução livre). ${ }^{71}$
\end{abstract}

Não satisfeito, um grupo de ulemás ajuizou uma ação judicial em 1976 com vistas a impedir os Ahmadis de chamarem seus locais de culto de mesquita (masjid), de usarem o chamado islâmico para oração (azan) e de recitarem versos do Corão, o que a Corte Superior de Lahore rejeitou (MAHMUD, 1995, p. 74).

Diante da ameaça de "ações diretas" por parte do movimento ressurgente, o regime de exceção do General Ziā-ul-ḥaq adotou uma série de medidas voltadas à islamização do sistema jurídico paquistanês. A mais importante delas, segundo Martin Lau, foi "criar um mecanismo institucional de islamizar o sistema jurídico independentemente do Parlamento. Pela primeira vez um tribunal especial foi instituído com o propósito explícito de rever judicialmente determinadas partes do sistema jurídico para determinar se elas estavam de acordo com o direito islâmico" (LAU, 2012, p. 196, tradução livre). Em 1984, editou a Ordenação XX, ${ }^{72}$ que introduziu os artigos 298-B e 298-C ao Código Penal paquistanês:

“298B. Utilização inapropriada de epítetos, descrições e títulos, etc., reservados a certos personagens ou locais sagrados.

(1) Qualquer pessoa do grupo Quadiani ou do grupo Lahori (que se autodenomine 'Ahmadis' ou qualquer outro nome) que, por meio de palavras, ditas ou escritas, ou por meio de representação visível,

\footnotetext{
71 Atualmente, artigo 260, § $3^{\circ}$, da Constituição do Paquistão (em sua versão atualizada até janeiro de 2015), dispõe: "Na Constituição e em todos os decretos e outros instrumentos legais, a menos que haja algo incompatível na matéria ou no contexto, (a) "Muçulmano" significa uma pessoa que acredita na unidade e singularidade de Allah Todo-Poderoso, no finamento absoluto e incondicional do Profetismo de Maomé (paz esteja com ele), o último dos profetas, e não acredita em nem reconhece como um profeta ou reformador religioso, qualquer pessoa que tenha afirmado ou alegue ser um profeta, em qualquer sentido da palavra ou de qualquer descrição que seja, depois de Maomé (paz esteja com ele); e (b) “não-muçulmano" significa uma pessoa que não é um muçulmano e inclui uma pessoa pertencente à comunidade cristã, hindu, sikh, budista ou parsi, uma pessoa do grupo Quadiani ou do grupo Lahori (que se autodenominem Ahmadis ou qualquer outro nome), ou um Bahai, e uma pessoa pertencente a qualquer uma das castas." (PAQUISTÃO. Constituição da República Islâmica do Paquistão, p. 155156, tradução livre. Disponível em: http://heinonline.org/HOL/Page?handle=hein.cow/zzpk0024\&collection=cow. Último acesso: 04 mai. 2016).

$72 \mathrm{O}$ título do texto normativo é "Anti-Islamic Activities of the Quadiani Group, Lahori Group and Ahmadis (Prohibition and Punishment) Ordinance, 1984” (SIDDIQ, 1995, p. 329).
} 
(a) refira-se ou dirija-se a qualquer pessoa, a não ser um Califa ou companheiro do Profeta Sagrado Maomé (paz esteja com ele), como 'Amìrul Mumineen' [Líder dos Fiéis], 'Khalifa-tul-Muslimeen' [Califa dos Muçulmanos], 'Sahaabi' (Companheiro) ou 'Razi Allah Anho' [que Deus esteja satisfeito com eles];

(b) refira-se ou dirija-se a qualquer pessoa, a não ser a esposa do Profeta Sagrado Maomé (paz esteja com ele), como 'Umul Mumineen' [Mãe dos Fiéis];

(c) refira-se ou dirija-se a qualquer pessoa, a não ser um membro da família (Ahle-Baith) do Profeta Sagrado Maomé (paz esteja com ele), como AhleBaith; ou

(d) refira-se a ou nomeie ou chame seu local de culto como 'masjid' [mesquita];

deve ser punida com prisão em qualquer dos regimes por um prazo que pode estender-se até três anos, e pode também ser sujeita a multa.

(2) Qualquer pessoa do grupo Quadiani ou do grupo Lahori (que se autodenomine 'Ahmadis' ou qualquer outro nome) que, por meio de palavras, ditas ou escritas, ou por meio de representação visível, refira-se ao modo ou à forma de chamar para as orações seguida por sua fé como 'Azan', ou recite 'Azan' como utilizado pelos muçulmanos, deve ser punida com prisão em qualquer dos regimes por um prazo que pode estender-se até três anos, e pode também ser sujeita a multa.

298C. Pessoa do grupo Quadiani, etc., chamando a si mesmo de muçulmano ou pregando ou propagando sua fé. Qualquer pessoa que, direta ou indiretamente, pose como muçulmana ${ }^{73}$ ou chame ou refira-se a sua fé como Islã, ou pregue ou propague sua fé, ou convide outras a aceitar sua fé, por meio de palavras ditas ou escritas, ou por meio de representações visíveis, ou de qualquer maneira que seja ofenda os sentimentos religiosos de muçulmanos, deve ser punida com prisão em qualquer dos regimes por um prazo que pode estender-se até três anos, e pode também ser sujeita a multa." (tradução livre a partir da transcrição contida na decisão do caso Zaheeruddin e em SIDDIQ, 1995, p. 329-330).

No ano seguinte, a Subcomissão das Nações Unidas sobre Prevenção da Discriminação e Proteção de Minorias aprovou a Resolução 1985/21, na qual denuncia que a Ordenação XX, "prima facie, viola o direito à liberdade e à segurança das pessoas, o direito à liberdade de pensamento, expressão, consciência e religião, o direito das minorias religiosas de professar e de praticar sua própria religião" (SIDDIQ, 1995, p. 334, tradução livre). O envolvimento da comunidade internacional demonstra que o caso dos Ahmadis coloca um problema sobre direitos humanos que pretendem valer para ordens jurídicas diversas existentes na sociedade mundial.

No caso Zaheeruddin v. State, a Suprema Corte do Paquistão em 1993 julgou conjuntamente cinco recursos criminais e três recursos cíveis que debatiam a

\footnotetext{
${ }^{73} \mathrm{Na}$ tradução da expressão "pose himself as a Muslim", optou-se por uma solução literal - "pose como muçulmana" -, com o objetivo de tentar expor o leitor ou a leitora a uma linguagem mais próxima do texto legislativo original. Entretanto, uma tradução possível e talvez mais fiel ao sentido da norma seja "fingir-se muçulmano". Agradeço a Amanda Visoto de Matos por essa sugestão.
} 
constitucionalidade da Ordenação XX à luz do artigo 20 da constituição paquistanesa, que alberga o direito à liberdade religiosa. Os recursos criminais diziam respeito a réus condenados à pena de um ano de prisão rigorosa ${ }^{74}$ e ao pagamento de multa no valor de mil rúpias ou a um mês adicional de prisão em caso de inadimplemento pelo crime previsto no artigo 298-C, transcrito acima. Especificamente, os réus, que pertenciam ao grupo Quadiani, foram acusados de terem vestido um distintivo contendo a kalima tayyab (Palavra de Pureza) e afirmado serem muçulmanos. ${ }^{75}$ Quanto aos recursos cíveis, rebatiam-se contra uma decisão do governo da região de Punjab que impedia a celebração do centenário da crença Ahmadi. ${ }^{76}$ A Suprema Corte do Paquistão, por maioria de votos,${ }^{77}$ declarou a constitucionalidade das proibições previstas na Ordenação XX e determinou que os réus retornassem à instituição carcerária para o cumprimento do restante de suas penas.

A fundamentação do voto majoritário repousa sobre quatro ideias principais. Em primeiro lugar, afirma que os Ahmadis não são muçulmanos. Para sustentar essa afirmação, o autor do voto majoritário, Justice Abdul Qadeer Chaudhry, baseia-se no texto do artigo 260, § $3^{\circ}$, da constituição paquistanesa (citado anteriormente), bem como em um pronunciamento anterior da Corte Federal da Sharī'a (Federal Shariat Court), ${ }^{78}$ de acordo com o qual Ahmadis não seriam muçulmanos, "pela razão de que [eles] não acreditam no finamento do profetismo de Maomé (Paz esteja com ele); falsificam um verso claro e geral do Corão Sagrado por intermédio de seu 'Taweel'; e importam para o Islã conceitos heréticos como shadowism, ${ }^{79}$ encarnação e transmigração" (PAQUISTÃO, 1993, sem paginação, tradução livre). De acordo com o Justice Chaudhry, os precedentes da Corte Federal da Sharī'a (que tem competência para julgar se as leis são incompatíveis com as determinações do Islã, tais como expressas no Corão

\footnotetext{
74 "Prisão rigorosa", segundo o art. 53 do Código Penal paquistanês, é aquela que inclui trabalho pesado.

${ }^{75}$ De acordo com o relato dos argumentos de defesa contido no voto minoritário, elaborado pelo Justice Shafiur Rahman, o advogado dos recorrentes afirmou, entre outras coisas, que "1790 casos criminais foram registrados contra essa minoria específica até 1992 e estão pendentes de julgamento em tribunais; 84 por oferecer preces diárias, 691 pelo uso da kalima tayyab, 36 por recitar o Azan, 251 por pregar a religião; 676 por posar como um muçulmano, 52 por usar expressões árabes islâmicas" (PAQUISTÃO, 1993, sem paginação, tradução livre).

${ }^{76}$ A decisão impedia as seguintes atividades: iluminação de prédios, a instalação de portões decorativos, a realização de procissões e de encontros, o uso de autofalante ou de megafone, a criação de slogans, a exibição de distintivos, bandeiras e banners, a distribuição de panfletos e a colagem de cartazes nos muros, a distribuição de doces e o serviço de comida, bem como qualquer outra atividade que pudesse direta ou indiretamente incitar e machucar os sentimentos religiosos dos muçulmanos. (PAQUISTÃ̃, 1993)

${ }^{77}$ Catorze Justices compunham a Suprema Corte do Paquistão, mas nove deles recusaram-se a participar do julgamento do caso Zaheeruddin v. State, por motivos desconhecidos (SIDDIQ, 1995, p. 277). O Justice Abdul Qadeer Chaudhry redigiu o voto majoritário, ao qual aderiram dois integrantes do órgão julgador.

${ }^{78}$ PAQUISTÃO. Federal Shariat Court. Criminal appeals n. 31-K to 35-K of 1988. Mujibur Rehman vs. Federal Government of Pakistan and another (PLD 1985 FSC 8).

${ }^{79}$ Optou-se por não traduzir a palavra "shadowism" em razão da falta de um substantivo equivalente em português. "Shadow", em inglês, traduz-se como "sombra". Desse modo, a palavra indica algo parecido com uma crença em sombras. A explicação mais provável é de que esta seja uma referência à afirmação de Mirza Ghulam Ahmad de que ele seria uma sombra do profeta Maomé.
} 
e na sunna do profeta), quando não são questionados na Turma Recursal da Sharī'a da Suprema Corte (Shariat Appellate Bench), assumem caráter vinculativo, até mesmo para a própria Suprema Corte. ${ }^{80}$

Observa-se, então, que os dispositivos do texto constitucional que vinculam a ordem jurídica estatal paquistanesa ao direito islâmico e que estabelecem meios institucionais de garantir a influência islâmica sobre as operações do sistema jurídico no nível reflexivo formam a norma jurídica do caso Zaheeruddin quanto à classificação das crenças Ahmadis como islâmicas. Nesse ponto, o programa normativo deriva do texto constitucional e do Corão. Os argumentos seguintes, por sua vez, baseiam-se em referências ao direito da Inglaterra, da Índia, da Austrália e, sobretudo, dos Estados Unidos, cuja jurisprudência integra a ratio decidendi. Em cada um deles, a Suprema Corte do Paquistão valeu-se de parte dos programas normativos de ordens jurídicas estrangeiras para garantir a passagem dos dados à conclusão, ${ }^{81}$ produzindo um texto decisório relevante para a discussão sobre transconstitucionalismo.

Nesse sentido, o tribunal aduz, em segundo lugar, que a proteção jurídica do comércio e das marcas que identificam produtos e serviços impede que se usem os sinais que têm um significado especial ou que podem induzir as pessoas a erro. Analiticamente, pode-se dividir o argumento em duas partes, quais sejam: a que enfatiza a proteção à propriedade industrial do criador ou do detentor de determinada marca; e a que se concentra no direito dos consumidores de não serem enganados ao adquirirem determinado produto.

Na primeira parte, a Suprema Corte do Paquistão invocou o direito inglês e as leis indianas para dar suporte à sua posição. Referiu-se ao precedente da Inglaterra (1961) em $J$. Bollinger e outros v. Costa Brava Company Limited, no qual se discutiu a possibilidade de usar o nome "Spanish Champagne" para designar um vinho espumante que não tinha sido produzido no distrito de Champagne, na França, considerando-se, ao final, que isso consubstanciaria comércio desonesto. Além disso, mencionou o Trade and Merchandise Marks Act (1958), estatuto indiano cujo Capítulo X penaliza a utilização fraudulenta de marcas e de designações comerciais, assim como o Código Penal e o Trade Marks Act (1940), aplicáveis tanto à Índia quanto ao Paquistão, sendo que este impede o uso do brasão de armas, do nome de Mohammed

\footnotetext{
${ }^{80}$ Em seu voto, Justice Chaudhry justifica essa asserção com base no artigo 203-G da constituição paquistanesa: "203G. Excetuando a hipótese prevista no Artigo 203F, nenhuma corte ou tribunal, incluindo a Suprema Corte e uma Corte Superior, deve cogitar procedimentos ou exercício de qualquer poder ou jurisdição a respeito de qualquer matéria incluída no poder ou jurisdição da Corte [Federal da Sharī’a]". A ressalva contida na parte inicial do dispositivo diz respeito à competência recursal da Suprema Corte.

${ }^{81}$ Remete-se o leitor ou a leitora ao modelo de análise dos argumentos proposto por Toulmin (2006, p. 135-175), de acordo com o qual garantias são afirmações de caráter geral que autorizam a passagem dos dados à conclusão, certificando a solidez do argumento.
} 
Ali Jinnah e do emblema da Organização das Nações Unidas para propósitos ligados ao comércio ou à profissão. Valendo-se desses programas normativos, afirmou:

\begin{abstract}
"Então, é claro que usar intencionalmente nomes comerciais, marcas comerciais, propriedade industrial ou descrições de outros com o objetivo de fazer outros acreditarem que eles pertencem ao usuário configura uma infração e não apenas o perpetrador pode ser preso, mas danos podem ser reparados e ordens para impedi-lo emitidas. Isso é verdade até para bens de valor muito pequeno. Por exemplo, a companhia Coca Cola não permitirá que qualquer um venda mesmo poucas onças de seu próprio produto em suas próprias garrafas ou outros receptáculos marcados Coca Cola, ainda que o preço possa ser alguns centavos. Além disso, é uma infração criminal com previsão de prisão e também de multa. Os princípios envolvidos são: não engane e não viole o direito de propriedade dos outros.”(PAQUISTÃO, 1993, sem paginação, tradução livre).
\end{abstract}

De acordo com a Suprema Corte, os réus no caso Zaheeruddin v. State não só desejariam uma autorização para passar sua fé como Islã, como também atribuiriam epítetos e descrições exclusivas dos personagens muçulmanos reverenciados a figuras heréticas, com o intuito de enganar as pessoas: "se os recorrentes ou sua comunidade não pretendessem enganar, por que não criam seus próprios epítetos etc.? Não percebem que depender das 'Shaairs' e outros sinais, marcas e práticas exclusivas de outras religiões denunciará o vazio de sua própria religião?" (PAQUISTÃO, 1993, sem paginação, tradução livre). ${ }^{82}$ Nesse ponto, cita o precedente em Cantwell v. Connecticut (1940), em que a Suprema Corte dos Estados Unidos diz, num obiter dictum, que nada do que estava afirmando insinuaria que "sob o manto da religião, pessoas podem, com impunidade, cometer fraudes contra o público" (ESTADOS UNIDOS, 1940, sem paginação, tradução livre).

Em nenhum momento a Suprema Corte do Paquistão tematiza a suposição subjacente a esse argumento, isto é, a de que existiria uma analogia entre o comércio e a religião, de tal modo que se possa entender como as previsões normativas relacionadas à propriedade industrial estabeleceriam restrições a práticas religiosas. Em nenhuma jurisdição estrangeira, entre aquelas mencionadas na decisão, já se construiu paralelo semelhante. ${ }^{83}$

\footnotetext{
${ }^{82}$ Em passagem posterior, Justice Chaudhry aduz enfaticamente: "Seu desapontamento é que eles [os Ahmadis] queriam esbulhar o resto dos muçulmanos como infiéis e reter o rótulo de muçulmanos. Sua mágoa, então, é que eles foram excomungados e rotulados como não-muçulmanos, injustamente. A razão de sua frustração e desalento pode ser que agora, provavelmente, eles não conseguem operar com sucesso seu esquema de conversão dos incautos e não-muçulmanos à sua fé. Talvez seja por essa razão que eles querem usurpar os epítetos e descrições muçulmanas e exibir 'Kalima' e recitar 'Azan' de modo a posar como muçulmanos e pregar e propagar nas vestimentas de muçulmanos com os princípios atraentes do Islã. O rótulo de não-muçulmano parece ter se tornado contraproducente" (PAQUISTÃO, 1993, sem paginação, tradução livre).

${ }^{83}$ Pelo contrário, M. Nadeem Ahmad Siddiq, em artigo seminal sobre o caso Zaheeruddin v. State, cita dois casos da jurisprudência estadunidense que afastariam essa possibilidade. No primeiro, MacDaniel v. Mirza Ahmad
} 
Em terceiro lugar, o tribunal sustenta que restrições à liberdade religiosa são admissíveis quando necessárias à manutenção da ordem pública. A Suprema Corte do Paquistão afirma que a liberdade religiosa divide-se entre a liberdade para crer e a liberdade para agir. Enquanto aquela é absoluta, esta é suscetível de restrições legais para proteção da sociedade. Embora cite o artigo do texto constitucional paquistanês que aborda a liberdade religiosa ao mesmo tempo em que a sujeita às prescrições da lei, da ordem pública e da moralidade, Justice Chaudhry vale-se, sobretudo, de parte dos programas normativos da ordem jurídica estadunidense para justificar a decisão.

Assim, faz referência ao caso Cantwell v. Connecticut, julgado pela Suprema Corte dos Estados Unidos em 1940, para sustentar que se faz necessário um equilíbrio entre a liberdade de agir de acordo com a religião e as restrições a práticas que possam colocar em risco a coletividade. Nesse caso, a Suprema Corte dos Estados Unidos julgou a constitucionalidade de uma lei estadual que exigia a autorização de uma autoridade administrativa para que as pessoas pudessem solicitar dinheiro, serviços ou qualquer coisa valiosa para fins religiosos ou filantrópicos, atribuindo a essa autoridade a competência de avaliar se a causa é realmente religiosa e se está de acordo com padrões razoáveis de eficiência e integridade. O caso dizia respeito a Testemunhas de Jeová que passaram de porta em porta em determinada rua oferecendo livros e pedindo contribuições para a publicação de panfletos. A Suprema Corte entendeu que a possibilidade de que o secretário do conselho de bem-estar público indeferisse o pedido de autorização caso entenda que a causa não é religiosa configura censura da religião e violação da liberdade religiosa e de expressão (ESTADOS UNIDOS, 1940).

Em seguida, aborda o caso Reynolds v. United States (ESTADOS UNIDOS, 1878), em que a Suprema Corte dos Estados Unidos julgou o caso de um mórmon condenado pelo crime de bigamia, discutindo se a crença religiosa do acusado justificaria um ato contrário às leis criminais do país e se a previsão da bigamia como tipo penal enquadrar-se-ia na proibição à emissão de textos legais tendentes a impedir o exercício livre da religião, como determina a primeira emenda à constituição dos Estados Unidos. Após dizer que essa proibição abrange o poder legislativo sobre opiniões, mas não sobre atos que violem deveres sociais ou subvertam

Sohrab (1941), em que se discutia o direito dos requeridos de falar sobre a fé Baha'i sem a autorização da liderança religiosa, a Suprema Corte do estado de Nova York afirmou que ninguém tem um monopólio sobre o nome de uma religião. No segundo, Christian Science Board of Directors of First Church of Christ v. Evans (1987), a Suprema Corte de Nova Jersey permitiu que uma igreja desse estado usasse o nome Christian Science Church, mesmo sem ser afiliada àquela homônima baseada em Boston, porque, em seu entendimento, nomes religiosos são genéricos e, por esse motivo, não estão sujeitos à proteção da marca registrada (SIDDIQ, 1995, p. 295-298). 
a ordem pública, a Suprema Corte dos Estados Unidos afirma que "Poligamia sempre foi odiosa entre as nações do norte e do oeste da Europa e, até o estabelecimento da Igreja Mórmon, era quase exclusivamente uma característica da vida dos povos asiáticos e africanos. Na common law, o segundo casamento sempre foi nulo" (ESTADOS UNIDOS, 1878, sem paginação, tradução livre). Aduziu que a legislatura do estado da Virgínia adotou em 8 de dezembro de 1788 a mesma lei do rei James I que punia a ofensa com pena de morte e que, desde aquela data, não houve qualquer momento em que a poligamia não tivesse sido considerada crime em todos os estados. Seguindo essa linha de raciocínio, concluiu que não há proibição à edição de textos legislativos sobre essa questão da vida em sociedade e que crenças religiosas não estariam acima das leis. Para Siddiq, a diferença entre o caso Zaheeruddin e o caso Reynolds consiste no fato de que "as leis banindo a poligamia antecediam as práticas religiosas em questão em Reynolds. As leis eram de aplicação geral e não se dirigiam a qualquer grupo específico" (SIDDIQ, 1995, p. 303, tradução livre).

A Suprema Corte do Paquistão refere-se também ao precedente dos Estados Unidos no caso Cox v. New Hampshire (1941), em que cinco Testemunhas de Jeová foram condenados com base em uma lei que proibia uma "parada ou procissão" em uma via pública sem uma licença especial. Nesse caso, a Suprema Corte dos Estados Unidos observou que a lei local em questão previa condições atinentes ao tempo, ao lugar e ao modo de realização de paradas ou procissões, com o objetivo de conservação da conveniência pública, o que não viola direitos constitucionais, mas salvaguarda a ordem pública de que eles dependem. Destacou que a lei não estabelece qualquer restrição à publicação de fatos ou de opiniões, nem à distribuição de literatura ou à exibição de cartazes, sendo aplicável a quaisquer conjuntos de pessoas que usem as vias públicas. Desse modo, concluiu que não se pode negar a autoridade do município "para dar consideração, sem discriminação injusta, ao tempo, local e maneira em relação aos outros usos adequados das ruas" (ESTADOS UNIDOS, 1941, sem paginação, tradução livre).

Por fim, ainda no que diz respeito ao argumento de que restrições à liberdade religiosa são cabíveis quando necessárias à preservação da ordem pública ou à defesa da sociedade, a decisão de Zaheeruddin v. State vale-se do precedente em Hamilton et al. $v$. Regents of the University of California (1934). Neste caso, a Suprema Corte dos Estados Unidos discutiu a constitucionalidade de uma lei estadual que obrigava os alunos da Universidade da Califórnia a receberem treinamento militar. Os estudantes que recorreram a esse tribunal eram membros da Igreja Episcopal Metodista e da Liga Epworth que solicitaram dispensa dessa obrigação em função de sua objeção religiosa e de consciência à guerra e ao treinamento militar, que reputavam contrários ao ensinamento de Jesus Cristo e aos preceitos da religião cristã. A 
universidade negou o pedido e suspendeu-os, condicionando sua readmissão ao cumprimento das regulações. A Suprema Corte dos Estados Unidos não identificou qualquer razão para acreditar que a exigência de que estudantes do sexo masculino com a compleição física saudável participem de treinamento militar transgredisse os direitos constitucionais dos recorrentes e afirmou, num trecho transcrito por Justice Chaudhry, que o governo tem o dever de "preservar a si mesmo com força adequada para manter a paz e a ordem e para garantir o cumprimento da lei. E todo cidadão é obrigado ao dever recíproco, de acordo com sua capacidade, de apoiar e de defender o governo contra todos os inimigos" (ESTADOS UNIDOS, 1934, sem paginação, tradução livre). Justice Benjamin Cardozo, da Suprema Corte dos Estados Unidos, em voto concorrente, disse que não enxergava qualquer obstrução ao exercício livre da religião.

Considerando o modelo de análise dos argumentos de Stephen Toulmin (2006, p. 135-175), os precedentes estadunidenses cumprem a função de garantia da passagem de certos dados à conclusão da Suprema Corte do Paquistão de que a Ordenação XX não viola o direito constitucional à liberdade religiosa. $\mathrm{O}$ voto majoritário transcreve trechos das publicações de Mirza Ghulam Ahmad e relata algumas de suas falas que ofenderiam os sentimentos religiosos da maioria sunita, incitando uma situação de conflito social. Exemplificativamente, Justice Chaudhry alega que Mirza Ghulam Ahmad teria escrito que "O Profeta Sagrado comia queijo feito por cristãos ao qual eles adicionavam gordura de porco" (PAQUISTÃO, 1993, sem paginação, tradução livre), o que teria sido uma transgressão pelo profeta de uma regra prevista no Corão, que proíbe o consumo de carne suína. Entretanto, de acordo com Siddiq (1995, p. 317), não existe qualquer registro de que Ghulam Ahmad tenha escrito isso. Não obstante esse relato na decisão de atos supostamente ofensivos dê azo a questionamentos quanto à sua validade no mundo objetivo, ele forma o conjunto de dados que levam Justice Chaudhry a perguntar: "Pode então qualquer um culpar um muçulmano caso ele perca controle de si mesmo ao ouvir, ler ou ver materiais blasfemos tais como produzidos por Mirza Sahib?" (PAQUISTÃO, 1993, sem paginação, tradução livre). Trocando em miúdos, isso significa que as práticas religiosas dos Ahmadis, na medida em que seriam aviltantes para os muçulmanos (dos quais Justice Chaudhry exclui os Ahmadis), provocariam reações violentas e gerariam o tipo de risco à ordem social que legitima restrições legais ao exercício livre da religião.

Diz-se que os precedentes cumprem a função de garantia no argumento, porque Justice Chaudhry não os utiliza como fundamento para a pretensão de correção normativa de asserções sobre o direito paquistanês num plano reflexivo. Além disso, a decisão do caso Zaheeruddin v. State não explicita quaisquer motivos por que o programa normativo estrangeiro 
seria relevante ou teria força persuasiva para a ordem jurídica paquistanesa. Se houvesse essa discussão, ela serviria de apoio, contribuindo para estabelecer a autoridade da garantia.

Por fim, a Suprema Corte do Paquistão responde à alegação dos recorrentes de que a Ordenação XX seria nula em razão da vagueza do texto normativo, em especial da expressão "posar como muçulmano", que impediria as pessoas de anteciparem quais são as condutas proibidas e cujo sentido estaria sujeito a construções arbitrárias. A doutrina da nulidade em razão da vagueza ("void-for-vagueness doctrine" ou simplesmente "vagueness doctrine") deriva do direito estadunidense, sobretudo da construção jurisprudencial em torno da cláusula do devido processo legal. No que tange à aplicação dessa doutrina aos recursos de Zaheeruddin et al., a Suprema Corte do Paquistão partiu da definição do dicionário das palavras "vago" e "posar" para afirmar que os recorrentes não haviam apontado em que ponto a lei seria vaga e que "será apenas uma questão de fato, a ser demonstrada por meio das provas, que os acusados tenham usado os epítetos etc. ou se sua atitude ou conduta corresponde ao que é previsto na lei" (PAQUISTÃO, 1993, sem paginação, tradução livre).

Além disso, mencionou os precedentes dos Estados Unidos em Lanzetta v. New Jersey (ESTADOS UNIDOS, 1939) e em Connally v. General Construction Company (ESTADOS UNIDOS, 1926) para traçar uma distinção conceitual entre "vagueza" e "amplitude" ("overbreadth") e para sustentar que só se pode considerar uma lei "vaga" quando pessoas de inteligência normal tiverem de adivinhar seu sentido ou divergirem quanto à sua aplicação. No primeiro desses precedentes, a Suprema Corte dos Estados Unidos declarou a inconstitucionalidade em razão da vagueza de um dispositivo da legislação do estado de Nova Jersey que dispunha:

\footnotetext{
"Qualquer pessoa não envolvida em qualquer ocupação lícita, conhecida por ser um membro de qualquer gangue constituída por duas ou mais pessoas, que tenha sido condenada pelo menos três vezes por ser uma pessoa desordeira, ou que tenha sido condenada por qualquer crime neste ou em qualquer outro estado, é declarada um gangster" (ESTADOS UNIDOS, 1939, sem paginação, tradução livre).
}

De acordo com a Suprema Corte dos Estados Unidos, “os termos que [o dispositivo] emprega para indicar o que ele pretende denunciar são tão vagos, indefinidos e incertos que ele deve ser rejeitado como contrário à cláusula do devido processo legal da Décima Quarta Emenda" (ESTADOS UNIDOS, 1939, sem paginação, tradução livre). Porém, o tribunal não desenvolve a distinção conceitual a que a Suprema Corte do Paquistão fez referência. 
Em Connally v. General Construction Company (1926), colocou-se em questão a constitucionalidade de uma lei estadual que determinava que "não menos do que a taxa salarial atual por dia na localidade onde o trabalho é desempenhado deve ser pago aos trabalhadores, mecânicos, carcereiros e zeladores nas instituições públicas [...] ou a outras pessoas empregadas por empreiteiros ou subempreiteiros na execução de qualquer contrato com o Estado" (ESTADOS UNIDOS, 1926, sem paginação, tradução livre). A Suprema Corte dos Estados Unidos considerou que as expressões "taxa salarial atual" ("current rate of wages") e "localidade" ("locality") são vagas, pois não denotam qualquer montante específico nem definem quais áreas constituem uma "localidade", dificultando que o empreiteiro cumpra a determinação; por isso, declarou a inconstitucionalidade da lei estadual.

Em resumo, a Suprema Corte do Paquistão considerou que a Ordenação XX não viola direitos fundamentais, por quatro razões: Ahmadis não são muçulmanos; a proteção jurídica ao comércio e às marcas abrange a proibição ao uso de sinais exclusivos do Islã por não muçulmanos; restrições à liberdade religiosa são admissíveis quando necessárias à garantia da ordem pública; e, por fim, o texto legislativo não é vago, tratando-se de um problema relacionado à prova saber se determinada pessoa fingiu ou não ser muçulmana. Partindo-se da premissa de que as referências a precedentes estrangeiros caracterizam-se como argumentos por analogia, identificam-se inconsistências argumentativas graves, em especial quanto ao nexo entre o âmbito do caso e as escolhas analógicas do Justice Chaudhry (KHAN, 2010, passim). Comentários à decisão do caso Zaheeruddin v. State destacam esse aspecto e de modo geral sustentam que aplicação correta da norma ou "holding" dos precedentes mencionados conduziria ao resultado oposto àquele que o tribunal paquistanês proclamou (MAHMUD, 1995; SIDDIQ, 1995; KHAN, 2010). Porém, não se dedicam a responder em que medida o uso de precedentes estrangeiros é exemplificativo de um diálogo transconstitucional ou, ao contrário, de uma indisposição da ordem jurídica para o aprendizado. No próximo capítulo, esboçar-se-á uma resposta a essa pergunta.

Não obstante o decurso de mais de duas décadas entre o anúncio da decisão e a confecção deste trabalho acadêmico, as questões que o caso Zaheeruddin v. State suscitam permanecem atuais, seja porque os artigos do Código Penal que a Ordenação XX introduziu permanecem em vigência, seja porque estudos mais recentes apontam a continuidade da perseguição religiosa aos Ahmadis no Paquistão (GRIM; FINKE, 2011, p. 191).

\subsection{Pluralismo religioso: Mahmud Sami Muhammad 'Ali Wasil v. o Ministro da Educação (Egito)}


Conforme visto anteriormente, o texto do artigo $2^{\circ}$ da constituição egípcia de 1971 dispunha que "O Islã é a religião do Estado, o árabe sua língua oficial e os princípios da sharīa islâmica uma fonte principal da legislação no Egito". Em 1980, uma emenda modificou o texto constitucional, substituindo o artigo indefinido "uma" pelo artigo definido "a", de modo que os princípios da sharī'a islâmica passaram a ser "a fonte principal da legislação no Egito".

Nessa época, enquanto o partido governante, liderado pelo Presidente Anwar alSādāt, supunha que caberia aos ramos políticos do governo determinar se a legislação conformava-se aos "princípios da sharī'a islâmica", os islamitas sustentavam que os tribunais teriam a obrigação de avaliar se a legislação era consistente com esses princípios e de declarar sua nulidade caso não fossem (LOMBARDI; BROWN, 2006, p. 391). Desde a instituição do controle de constitucionalidade na ordem jurídica egípcia, a Suprema Corte Constitucional tem sido convocada a decidir sobre a constitucionalidade de atos legislativos com base no artigo $2^{\circ}$ da constituição. De acordo com Kristen Stilt, "A relativa autonomia da corte tornava-a um fórum atraente para islamitas que estavam descontentes com vários aspectos do direito egípcio" (STILT, 2013, p. 80-81, tradução livre).

Há dois caminhos por meio dos quais a Suprema Corte Constitucional pode exercer o controle de constitucionalidade, que lhe cabe com exclusividade. Em primeiro lugar, quando um tribunal observa que a lei ou o regulamento administrativo com base no qual deve decidir certo caso é inconstitucional, ele suspende o processo e determina sua remessa à Suprema Corte para a apreciação das questões constitucionais. Em segundo, se a parte questiona a constitucionalidade de determinada previsão legal perante um tribunal e este considera o argumento plausível, suspende-se o processo por um prazo máximo de três meses, durante o qual a questão deve ser apresentada à Suprema Corte Constitucional (STILT, 2013, p. 80-81).

$\mathrm{O}$ primeiro caso que chegou à Suprema Corte Constitucional do Egito sobre as implicações do artigo $2^{\circ}$ da constituição discutia constitucionalidade de um dispositivo do Código Civil que previa o acréscimo de juros às dívidas em atraso. A faculdade de medicina da al-Azhar havia deixado de pagar um fornecedor de suprimentos médicos no termo acordado, o qual lhe exigiu o pagamento com juros. A instituição alegou que a cobrança era incompatível com a proibição do direito islâmico a ribā (usura ou juros), isto é, ao recebimento de vantagem monetária sem a oferta de qualquer contrapartida em determinada transação comercial (SCHACHT, 1964, p. 145), ${ }^{84}$ e, por conseguinte, seria também inconstitucional. A Suprema

\footnotetext{
${ }^{84}$ Essa proibição deriva de versos do Corão, tais como: 2:275 (“Os que praticam a usura serão ressuscitados como
} aquele que foi perturbado por Satanás; isso, porque disseram que a usura é o mesmo que o comércio; no entanto, 
Corte Constitucional rejeitou a alegação de al-Azhar, estabelecendo o que veio a ficar conhecido como "doutrina da não-retroatividade": de acordo com o tribunal, o artigo $2^{\circ}$ da constituição aplica-se apenas à legislação aprovada após 22 de maio de 1980, quando o texto desse dispositivo passou a prever que os princípios da sharī' $a$ são a fonte principal da legislação no Egito. Como a adoção do Código Civil deu-se em 1949, as regras previstas nele não estão sujeitas à avaliação de constitucionalidade com base no artigo $2^{\circ}$ (HIRSCHL, 2004, p. 18241825; STILT, 2013, p. 97-98). Segundo Ran Hirschl, "Enquanto a decisão da corte foi aclamada como uma vitória pelo governo e pelos setores financeiros e empresariais do Egito, foi um golpe devastador para islamitas revivalistas que descreviam a aplicação não-retroativa do artigo $2^{\circ}$ como uma decisão orientada politicamente" (HIRSCHL, 2004, p. 1825, tradução livre) ${ }^{85}$ Em contrapartida, Clark B. Lombardi e Nathan J. Brown afirmam que "essa doutrina deu a cada lado uma vitória parcial. Ela permitiu à SCC retratar-se como um árbitro neutro. Ao mesmo tempo, a decisão teve o efeito positivo de dar à corte tempo para desenvolver um método de interpretação dos princípios da sharī’a islâmica" (LOMBARDI; BROWN, 2006, p. 393, tradução livre).

O caso em que se desenvolveu esse "método" - para usar o termo de Lombardi e Brown (2006) ou Arafa (2016), embora, sob a perspectiva teórica que este trabalho assume como ponto de partida, talvez se pudesse falar mais precisamente em "processo de concretização" (NEVES, 2012, p. 200-203) - foi Mahmud Sami Muhammad 'Ali Wasil v. o Ministro da Educação (Caso n. 8 do Ano Judicial 17, de 18 de maio de 1996). Nele, o pai de duas meninas questiona a constitucionalidade de uma decisão do Ministro da Educação ${ }^{86}$ que regulamenta a vestimenta das crianças em idade escolar, proibindo estudantes do sexo feminino de utilizarem um véu que cubra o rosto. Assim, a decisão permite o uso do hijab, tipo de véu que oculta o cabelo e o pescoço, nos níveis preparatório e secundário, mediante autorização do guardião, mas não o uso do niqab, que cobre quase toda a face, deixando apenas os olhos

\footnotetext{
Allah consente o comércio e veda a usura. Mas, quem tiver recebido uma exortação do seu Senhor e se abstiver, será absolvido quanto ao passado, e seu julgamento só caberá a Allah. Por outro lado, aqueles que reincidirem, serão condenados ao inferno, onde permanecerão eternamente"); 3:130 ("Ó crentes, não exerçais a usura, dobrando e multiplicando (o emprestado) e temei a Allah para que prospereis"); 4:161 ("E por praticarem a usura, sendo que isso lhes estava proibido, e por usurparem os bens alheios com falsas pretensões. E preparamos para os incrédulos, dentre eles, um doloroso castigo"); e 30:39 ("Quando emprestardes algo com usura, para que vos aumente (em bens), às expensas dos bens alheios, estes não vos aumentarão perante Allah; contudo, o que derdes na forma de zakat, anelando contemplar o Rosto de Allah (ser-vos-á aumentado). A eles será duplicada a recompensa").

${ }^{85}$ No mesmo sentido, isto é, afirmando o caráter preponderantemente político da decisão, o Professor Mohamed A. Arafa manifestou-se durante a aula proferida em 25 de maio de 2016 na disciplina Islamic Law and Comparative Middle Eastern Legal and Political Studies, ofertada pelo Programa de Pós-Graduação em Direito da Universidade de Brasília no primeiro semestre de 2016.

86 "Decisão", na ordem jurídica egípcia, corresponde a um tipo de regulamento administrativo (BROWN; LOMBARDI, 2006, p. 442, nota de rodapé n. ${ }^{\circ} 8$ ).
} 
expostos. ${ }^{87}$ Em uma decisão posterior, o Ministro da Educação esclareceu que "O guardião deve estar ciente da escolha da aluna de vestir uma cobertura para o cabelo e [deve estar ciente de que a escolha] vem de seu próprio desejo sem pressão ou imposição de uma pessoa ou parte outra além do guardião" (BROWN; LOMBARDI, 2006, p. 445, tradução livre). No caso específico, as filhas do requerente foram expulsas da escola em razão da decisão que veda o uso do niqab, a qual - ele sustentou - contradiz o artigo $2^{\circ}$ e o artigo 41 da constituição egípcia, segundo o qual "Liberdade pessoal é um direito natural não sujeito a violação exceto em casos de flagrante delito" (BROWN; LOMBARDI, 2006, p. 442, tradução livre). ${ }^{88}$ Além disso, exercendo sua jurisdição ex officio, a Suprema Corte Constitucional observa que o caso também diz respeito à liberdade religiosa, protegida pelo artigo 46 da constituição, nos seguintes termos: "O Estado deve garantir a liberdade de crença e a liberdade de praticar ritos religiosos" (BROWN; LOMBARDI, 2006, p. 443, tradução livre). ${ }^{89}$

Em sua decisão, a Suprema Corte Constitucional do Egito afirma que "Não é permitido para um texto legislativo contradizer aquelas regras ["rulings"] da sharì'a que são absolutamente certas a respeito de sua autenticidade e sentido [...], considerando que apenas essas regras são aquelas para as quais ijtihad é proibida" (BROWN; LOMBARDI, 2006, p. 446, tradução livre). E prossegue:

\begin{abstract}
"Em matérias em que não existam textos [escriturais claros quanto ao ponto], ijtihad é restringida apenas pelos controles universais [da sharī'a]. [E em tais matérias,] contanto que os objetivos [da sharī'a] não sejam obstruídos, não é permitido obrigar o wali al-amr [governante] a [seguir meras] opiniões em matérias de regras jurídicas islâmicas práticas [...]. Tampouco [é permitido] repousar sobre ijtihad pertencente a um momento [anterior] específico no tempo, como se [por meio dessa ijtihad antiga] os interesses jurídicos apropriados já tenham sido estabelecidos. [...] estabelece-se - à luz do que precede - que se deixa ao wali al-amr legislar sobre uma questão disputada [...]." (BROWN; LOMBARDI, 2006, p 449-450, tradução livre) ${ }^{90}$
\end{abstract}

\footnotetext{
${ }^{87}$ Faz-se necessário ter em linha de conta que o uso do niqab no Egito tende a ser associado com a fidelidade ao islamismo radical e à luta por vezes violenta contra o governo secular.

${ }^{88}$ Vale lembrar que o caso foi julgado sob a ótica da constituição de 1971. Com a redação ligeiramente diferente, o direito à liberdade pessoal está previsto no art. 54 da constituição de 2014.

${ }^{89}$ Equivalente ao artigo 64 da constituição de 2014: "Liberdade de crença é absoluta. A liberdade de praticar rituais religiosos e de estabelecer locais de culto para os seguidores das religiões reveladas é um direito organizado pela lei" (tradução livre).

${ }^{90} \mathrm{Na}$ tradução do texto da decisão para a língua inglesa, Nathan J. Brown e Clark B. Lombardi mantiveram, entre parênteses, as expressões árabes que indicam ideias ou conceitos sem correspondência óbvia ou necessária no inglês. Na transcrição desse trecho e em sua tradução para o português, algumas delas foram removidas, a fim de facilitar a leitura.
} 
Em outras palavras, de acordo com a Suprema Corte Constitucional, a legislação deve conformar-se àquelas regras do direito islâmico que sejam certas quanto à autenticidade e quanto ao sentido e aos objetivos da sharī'a. O tribunal considera os versos do Corão autênticos por si sós, mas não esclarece qual o critério para definir se determinado hadīth é autêntico. Quanto à certeza sobre o sentido, excluem-se quaisquer previsões que sejam vagas, ambíguas ou a respeito das quais exista divergência. A Suprema Corte Constitucional não adota a doutrina clássica do ijmā; por conseguinte, não aceita como vinculativa a regra que os juristas de determinada geração tenham extraído por consenso das fontes sagradas, embora percorra o trabalho desses estudiosos para saber se existe ou não desacordo acerca do sentido de determinado excerto do Corão ou da sunna. Sempre que se constatar a existência desse tipo de divergência, a lei ou regulamento em questão não pode ser considerado inconstitucional com base no artigo $2^{\circ}$, pois compete ao wali al-amr (governante) editar textos normativos que elejam uma entre as disposições plausíveis, à luz das circunstâncias atuais da sociedade.

Perfilhando essa linha de raciocínio, a Suprema Corte Constitucional passa a investigar se existem versos no Corão que definam com precisão regras sobre a vestimenta das mulheres. Embora afirme que elas não têm liberdade de escolher suas roupas, na medida em que o Islã impõe-lhes que se protejam da vergonha e da degradação (BROWN; LOMBARDI, 2006, p. 452), o tribunal consigna que "A forma de suas roupas e a aparência não são [contudo] fixadas por textos escriturais que tenham sido considerados certos seja quanto à sua autenticidade ou quanto a seu sentido [...] Isso [i.e. a forma de roupas e a aparência] são matérias sobre as quais ijtihad nunca para" (BROWN; LOMBARDI, 2006, p. 452, tradução livre). Nesse sentido, a Suprema Corte Constitucional menciona os seguintes versos corânicos:

\footnotetext{
"Dize às crentes que recatem os seus olhares, conservem os seus pudores e não mostrem os seus atrativos, além dos que (normalmente) aparecem; que cubram o colo com seus véus e não mostrem os seus atrativos, a não ser aos seus esposos, seus pais, seus sogros, seus filhos, seus enteados, seus irmãos, seus sobrinhos, às mulheres suas servas, seus criados isentos das necessidades sexuais, ou às crianças que não discernem a nudez das mulheres; que não agitem os seus pés, para que não chamem a atenção sobre seus atrativos ocultos." (Corão, 24:31)

"Ó Profeta, dize às tuas esposas, tuas filhas e às mulheres dos crentes que (quando saírem) se cubram com as suas mantas; isso é mais conveniente, para que se distingam das demais e não sejam molestadas; sabei que Allah é Indulgente, Misericordiosíssimo." (Corão, 33:59)
}

Esses excertos, de acordo com o tribunal, não autorizam a conclusão de que a vestimenta de uma mulher esteja entre as matérias de devoção que não podem ser alteradas. 
Pelo contrário, "o wali al-amr tem autoridade absoluta de legislar regras práticas dentro dessa moldura, limitando a forma do vestuário ou da roupa à luz do que prevalece em sua sociedade entre as pessoas de modo que seja apropriado com suas tradições e costumes" (BROWN; LOMBARDI, 2006, p. 453, tradução livre). A sharī’a islâmica - diz a Suprema Corte Constitucional - exige a regulamentação da vestimenta feminina, a fim de que a posição da mulher na sociedade seja elevada e de que ela não seja definida por sua animalidade. Essa regulamentação não deve submetê-la a situações constrangedoras, "como seria o caso se todo o seu corpo fosse considerado 'awra" (BROWN; LOMBARDI, 2006, p. 454, tradução livre). ${ }^{91}$ Em vez disso, deve equilibrar a necessidade de exibir sua piedade com a ausência de restrições a seus movimentos nem a suas atividades em sociedade.

Então, "Não há indicação (dalil) nos textos corânicos ou em nossa honrada sunna de que a vestimenta feminina juridicamente adequada, para ser aprovada pela $\operatorname{shar}_{\bar{l}} a$, deve cobri-la totalmente" (BROWN; LOMBARDI, 2006, p. 456, tradução livre). A autoridade governamental tem o direito de produzir a própria ijtihad sobre o assunto, desde que não contradiga os objetivos da sharì'a, os quais, no caso concreto, foram observados, na medida em que a decisão do Ministro da Educação atende à finalidade da modéstia. Logo, essa decisão não é contrária ao texto do artigo $2^{\circ}$ da constituição.

Em relação à liberdade religiosa, a Suprema Corte Constitucional do Egito distingue entre a liberdade de crença, que impede que se force uma pessoa a aceitar determinada fé religiosa ou a renunciar à sua religião e que não inclui a proteção a práticas que prejudiquem outras crenças, e a liberdade de prática dos rituais religiosos, que é uma manifestação da primeira, mas pode ser limitada por interesses superiores, "em particular, o que a conecta com a proteção da ordem pública e com valores éticos e com a defesa dos direitos de outros e de suas liberdades" (BROWN; LOMBARDI, 2006, p. 458, tradução livre). A semelhança em relação ao argumento da Suprema Corte do Paquistão no caso Zaheeruddin et al. v. State é notável e exemplifica um problema comum aos países do mundo islâmico no que tange à eficácia do direito fundamental à liberdade religiosa, que são as restrições infraconstitucionais a seu exercício pleno. De acordo com a corte egípcia, a decisão ministerial "não infringe a liberdade de crença, destrói suas fundações ou obstrui os ritos da prática [religiosa]. Ela não desafia a essência da religião ( $\operatorname{din})$ nas fontes universais sobre as quais a sharī’a é fundada"

\footnotetext{
${ }^{91}$ Brown e Lombardi explicam, em nota de rodapé, que o termo 'awra é quase impossível de traduzir, referindose às partes do corpo que são inerentemente sexuais.
} 
(BROWN; LOMBARDI, 2006, p. 458, tradução livre). Para Mohamed Arafa, ${ }^{92}$ ao afastar a alegação de violação ao artigo 46 da constituição, a Suprema Corte Constitucional proferiu uma decisão discriminatória em relação àquelas pessoas que compreendem o uso do niqab como uma obrigação religiosa. Conquanto o objeto principal deste trabalho não seja a discussão sobre a correção normativa dos processos de concretização do direito fundamental à liberdade religiosa, há de se concordar com essa opinião.

Por fim, em relação ao argumento do requerente de que a decisão do Ministro da Educação atingiria indevidamente a liberdade pessoal protegida pelo artigo 41 da constituição, a Suprema Corte Constitucional afirmou que o ato normativo não se localiza na esfera pessoal, mas no âmbito de bem-estar público em que se enquadram estudantes do sexo masculino e do sexo feminino nos estágios primário, secundário e intermediário de educação. A liberdade individual não impede o legislador de agir na esfera dos assuntos públicos, como é o caso da vestimenta de estudantes em idade escolar, que contribui para que não se misturem com outras pessoas e para que se lide melhor com eles. Além disso, a educação é supervisionada pelo Estado, conforme as necessidades da sociedade. A regulação justifica-se em função da conexão lógica entre seu conteúdo e seus objetivos: "a vestimenta [dos estudantes] torna-os conhecidos [como estudantes], indicando-os como tais, protegendo sua saúde psicológica e mental, não perturbando seus valores religiosos e não os dividindo" (BROWN; LOMBARDI, 2006, p. 460, tradução livre). Logo, a decisão ministerial não viola a liberdade pessoal.

Para Lombardi e Brown (2006, p. 429), o fato de o direito internacional dos direitos humanos incluir o direito de participação das mulheres na sociedade é um fator que pode ter contribuído para o resultado do julgamento. Porém, a ausência de elementos textuais que evidenciem a incorporação do direito internacional, tais como referências a tratados ou convenções internacionais sobre direitos humanos ou a precedentes das cortes internacionais e supranacionais, dificulta a corroboração dessa asserção. Isso pode causar dúvida sobre o motivo da inclusão do caso entre aqueles discutidos neste trabalho, tendo em conta que seu objetivo, exposto na introdução e ao longo do texto, consiste na discussão acerca da interação entre ordens jurídicas distintas. Diante disso, convém adiantar que se espera avaliar, no próximo capítulo, a possibilidade de compreender a decisão do caso Mahmud Sami Muhammad 'Ali Wasil v. o Ministro da Educação como um exemplo de transconstitucionalismo entre a ordem jurídica estatal egípcia e a tradição jurídica islâmica.

\footnotetext{
${ }^{92}$ Referência às aulas ministradas na disciplina "Islamic Law and Comparative Middle Eastern Legal and Political Studies", ofertada pelo Programa de Pós-Graduação em Direito da Universidade de Brasília no primeiro semestre letivo de 2016.
} 
Nos últimos anos, o Egito passou por momentos constitucionais tumultuados, conforme se discutirá adiante, no tópico sobre a Primavera Árabe. Desde 1996, quando a Suprema Corte Constitucional anunciou o resultado do caso, o país adotou dois textos constitucionais novos, em 2012 e em 2014. Em cada um desses momentos, o papel do Islã no Estado e, sobretudo, a relação entre a sharī'a islâmica e a ordem jurídica estatal destacou-se como um dos temas centrais para o povo e para as instituições egípcias. No texto constitucional de 2012, a disputa política entre não-islamitas, que apoiavam a abordagem modernizante da Suprema Corte Constitucional, e salafitas, que desejavam deslocar a definição dos princípios da sharī'a para as mãos de estudiosos religiosos em quem eles confiassem, provocou a introdução do artigo 219, que inclui entre esses princípios, por intermédio de uma linguagem neo-tradicionalista, aspectos do direito islâmico clássico, como as fontes, a ciência do direito (fiqh) e as proposições das escolas doutrinárias (madhahib) (LOMBARDI; BROWN, 2012, sem paginação). Entretanto, a constituição vigente, promulgada em 2014, suprimiu a tentativa de aproximar o sentido do artigo $2^{\circ}$ daquele que os islamitas pretendiam lhe atribuir, adotando, quanto a esse dispositivo, o mesmo texto da constituição de 1971, tal como este passou a dispor após a emenda de 1980. A pesquisa que subsidia este trabalho indica que a decisão da Suprema Corte Constitucional do Egito no caso Mahmud Sami Muhammad 'Ali Wasil v. o Ministro da Educação é aquela citada com mais frequência quando o estudo do direito constitucional comparado volta suas atenções ao Oriente Médio e ao Norte da África. A toda evidência, continua sendo um marco da jurisdição constitucional nos países do mundo islâmico, razão pela qual não se pode ignorá-la.

\subsection{Democracia e direito: Refah Partisi et al. v. Turquia (Corte Europeia de Direitos Humanos)}

Mustafa Kemal foi o comandante militar que liderou a defesa do Império Otomano na península de Galípoli durante a Primeira Guerra Mundial. Ele ganhou proeminência depois de impedir a invasão dos Aliados nessa região. Encabeçou o movimento nacionalista após o colapso do Império Otomano e obteve êxito na Guerra de Liberação (1919-1922), tornando-se o fundador da República da Turquia, conforme se depreende do preâmbulo do texto constitucional atual: “[...] em linha com o conceito de nacionalismo introduzido pelo fundador da República da Turquia, Atatürk, o líder imortal e o herói sem rival, e suas reformas e princípios" (TURQUIA, 1982, p. 1, tradução livre). 
Desde 1921 até sua morte, em 1938, Mustafa Kemal Atatürk governou a Turquia, promovendo uma agenda de modernização da ordem jurídica estatal. O nacionalismo baseado na língua e na história turcas, o republicanismo e o secularismo são características da ideologia política que orientou as reformas de Atatük e que mais tarde recebeu o nome de "kemalismo". Destaca-se, entre essas reformas, a abolição do califado, em 1924, "um passo significativo no caminho do secularismo" (KOÇAK, 2010, p. 242, tradução livre), que expressava o propósito de substituir o sentimento de pertencimento à comunidade muçulmana por uma identidade nacional turca. O Partido Republicano Popular (tradução livre a partir do inglês Republican People's Party), que Atatürk presidiu, governou de maneira totalitária até 1945, quando se introduziu um sistema pluripartidário na Turquia (KOÇAK, 2010, p. 245).

Entretanto, o banimento de partidos políticos é um acontecimento comum na história política turca: “de 1923 a 1996, os tribunais turcos dissolveram ou baniram trinta e oito partidos políticos" (SCHILLING; SPADA, 2003, p. 503, tradução livre). Em 1952, as autoridades judiciárias dissolveram o Partido Islâmico Democrático e submeteram seus fundadores a uma investigação criminal, tendo em conta que o Código Penal de 1926 previa o crime de "estabelecer, organizar ou administrar associações com o objetivo de adaptar os fundamentos da ordem estatal a regras e crenças religiosas, contrárias ao secularismo, ou encorajar outros a filiarem-se a esse tipo de associação" (KOÇAK, 2010, p. 245, tradução livre). Dois anos depois, uma ordem judicial dissolveu o Partido da Nação, sob o fundamento de que ele estaria envolvido em atividades subversivas. Em 1960, houve um golpe militar. As forças armadas assumiram o poder e promulgaram uma constituição nova. O Partido da Justiça venceu as eleições de 1965, explorando o fator religioso em sua campanha. Em 1969, criou-se o Partido da Ordem Nacional (Milli Nizam Partisi ou National Order Party, em inglês), sob a liderança de Necmettin Erbakan, como a face institucional do movimento que se baseava no Islã como ideologia política. A Corte Constitucional da Turquia extinguiu-o pouco depois, por valer-se da religião para obter ganhos políticos; porém, no ano seguinte, ele ressurgiu como o Partido Islâmico da Salvação Nacional (Milli Selamet Partisi ou Islamic National Salvation Party, em inglês) (GULALP, 1999, p. 22; KOÇAK, 2010, p. 245-247).

Em 1980, mais um golpe militar aconteceu. Fecharam-se todos os partidos políticos. O Conselho Constitutivo, formado por militares do Conselho de Segurança Nacional e por civis, esboçou o texto constitucional que a Turquia veio a adotar por meio de um referendo em 1982 e que permanece em vigência até os dias de hoje. Seguindo o kemalismo, o preâmbulo da constituição diz: "Nenhuma proteção será concedida a uma atividade contrária [...] [a]o nacionalismo, princípios, reformas e civilizacionismo de Atatürk e sentimentos religiosos 
sagrados não devem absolutamente ser envolvidos em questões e políticas estatais, como exigido pelo princípio do secularismo" (TURQUIA, 1982, p. 1-2, tradução livre). O artigo $2^{\circ}$ dita que "A República da Turquia é um Estado democrático, secular e social governado pelo Estado de Direito, dentro das noções de paz pública, solidariedade nacional e justiça, respeitando direitos humanos, leal ao nacionalismo de Atatürk, e baseada nos princípios fundamentais estabelecidos no preâmbulo" (TURQUIA, 1982, p. 3, tradução livre).

Em 19 de julho de 1983, ex-integrantes do Partido Islâmico da Salvação Nacional fundaram o Refah Partisi ou Partido do Bem-Estar Social (em tradução livre a partir do inglês Welfare Party). ${ }^{93}$ Nas eleições de 1995 , ele obteve $22 \%$ dos votos, tornando-se o maior partido político da Turquia, com 158 assentos na Grande Assembleia Nacional (que é o órgão legislativo em nível nacional da Turquia), mas não atingiu uma quantidade suficiente de votos para formar um governo majoritário. No ano seguinte, chegou ao poder por meio de uma coalizão com um partido de centro-direita (Doğru Yol Partisi ou True Path Party, em inglês), ${ }^{94}$ alçando Necmettin Erbakan à posição de Primeiro Ministro. Além disso, uma pesquisa de opinião de 1997 indicava que o Refah Partisi poderia obter até 67\% dos votos nas eleições gerais previstas para quatro anos depois (CORTE EUROPEIA DE DIREITOS HUMANOS, 2003, p. 4).

Todavia, em 21 de maio de 1997, o Principal State Council ${ }^{95}$ requereu a dissolução do partido à Corte Constitucional da Turquia, argumentando de que ele constituiria um "centro" de atividades contrárias ao princípio do secularismo. Como evidências da verdade dessa

\footnotetext{
${ }^{93}$ Há uma linha de continuidade entre o Partido Islâmico da Salvação Nacional e o Refah Partisi ou Partido do Bem-Estar Social, que se manifesta, segundo Gulalp (1999, p. 26), nos trechos dos respectivos programas em que se estabelece o objetivo de alcançar uma "ordem moral" ou uma "ordem econômica justa", que se distinguiria tanto do capitalismo como do comunismo, que se baseariam na busca do interesse próprio. Mesmo assim, verificam-se também diferenças, como, por exemplo, na ênfase que o Partido Islâmico da Salvação Nacional concedia à necessidade de industrialização.

94 “A coalizão Refah-TPP foi à primeira vista uma dupla verdadeiramente estranha, porque o TPP vinha construindo sua campanha, por muitos anos antes disso, sobre a promessa de ser o principal bastião pró-Ocidente e secular anti-Refah. A justificativa para essa aliança sob o ponto de vista do TPP foi melhor articulada por Çiller em uma entrevista em um canal de televisão pró-islamita alguns meses depois da criação da coalizão. Ela declarou que embora ainda fosse a favor do princípio do secularismo e não muitíssimo afeiçoada ao Refah, ela acreditava que levar o Refah ao centro da política turca era o único modo de manter a paz social e de preservar a democracia" (GULALP, 1999, p. 36, tradução livre).

95 "Principal State Council" é a expressão com a qual a Corte Europeia de Direitos Humanos refere-se à autoridade estatal com competência para atuação judicial em favor do Estado na Turquia. Do relato sobre o caso que a CEDH faz em sua decisão, depreende-se que as funções do Principal State Council parecem com aquelas do Ministério Público no direito constitucional brasileiro. Nesse sentido, Schilling (2003, p. 503) refere-se a essa autoridade como "Attorney General” ou Procurador-Geral, em tradução livre. Cabe assinalar que o texto da constituição turca disponível em inglês no site da Grande Assembleia Nacional da Turquia não contém essa expressão, de modo que o paralelo entre o Principal State Council e o Ministério Público brasileiro, conquanto útil para fins didáticos, carece de um exame mais profundo à luz de sua regulamentação. Tendo em conta a dificuldade inerente à tradução do nome de instituições estatais estrangeiras, utilizar-se-á a expressão da CEDH, sem traduzi-la.
} 
asserção, disse que o presidente do Refah Partisi, Necmettin Erbakan, além de outros líderes partidários, teriam defendido o uso do véu islâmico nas escolas e nas repartições públicas; que Erbakan teria apresentado propostas tendentes à supressão do secularismo em uma reunião sobre reforma constitucional, incluindo a de que as pessoas obedecessem às regras da religião que seguiam em vez das normas previstas na ordem jurídica estatal; que, no ano de 1991, Erbakan teria convidado fiéis muçulmanos para filiarem-se ao Refah, afirmando que somente esse partido poderia "estabelecer a supremacia do Corão por meio de uma guerra santa (jihad)" (CEDH, 2003, p. 4, tradução livre); que, durante o Ramadã, Erbakan teria recebido chefes de movimentos islamitas para um jantar na residência oficial do Primeiro Ministro; que membros do partido teriam clamado pela adoção de um sistema teocrático, sem que as instâncias partidárias tenham iniciado procedimentos disciplinares contra eles, o que revelaria o apoio institucional tácito a essa visão; que um parlamentar do Refah Partisi chamado Ibrahim Halil Çelik teria dito a jornalistas que lutaria até o fim pela introdução da sharī’a; que o Ministro da Justiça e vice-presidente do partido, Şevket Kazan, teria expressado seu apoio ao visitar um prefeito preso enquanto respondia a um processo penal por vindicar publicamente grupos terroristas islamitas internacionais (CEDH, 2003, p. 4-5).

A Corte Constitucional da Turquia acolheu o pedido do Principal State Council. Em janeiro de 1998, ela dissolveu o Refah Partisi, sob o fundamento de que o partido teria se tornado um "centro de atividades contrárias ao princípio do secularismo" (CEDH, 2003, p. 7). Além disso, cassou os mandatos de seis parlamentares e impediu-os de fundar ou de participar de qualquer organização partidária por cinco anos. O tribunal declarou a inconstitucionalidade do dispositivo legal que previa a necessidade de condenação criminal dos membros de um partido como condição para que se pudesse considerá-lo um "centro" de atividades contrárias aos princípios fundamentais da república e afastou o argumento de que os pronunciamentos dos líderes partidários estariam acobertados pela imunidade parlamentar, porque isso não teria relação com a pretensão de dissolução da agremiação (CEDH, 2003, p. 7). Construiu a norma de decisão com base na lei sobre a regulamentação dos partidos políticos, que dispõe:

\footnotetext{
"Seção 78

'Partidos políticos

...não devem ter por objetivo ou incitar terceiros a

- colocar em perigo a existência do Estado e da República da Turquia, abolir direitos e liberdades fundamentais, introduzir a discriminação com base na língua, raça, cor, religião ou pertencimento a uma religião, ou estabelecer, por quaisquer meios, um sistema de governo baseado em qualquer dessas noções ou conceitos.
} 
Seção 90(1)

'A constituição, o programa e as atividades de partidos políticos não podem infringir a Constituição ou esta Lei.’

Seção 101

'A Corte Constitucional dissolverá um partido político

(b) quando sua assembleia geral, escritório central ou comitê executivo ... tomar uma decisão, emitir uma circular ou fizer um pronunciamento ... contrário às previsões do Capítulo 4 desta Lei [Esse capítulo (da seção 78 à seção 97, que trata das restrições sobre as atividades de partidos políticos, prevê, inter alia, que tais atividades não podem ser praticadas em detrimento da ordem constitucional democrática (incluindo a soberania do povo e eleições livres), da natureza da nação e da natureza secular do Estado (incluindo observância das reformas levadas a cabo por Atatürk, a proibição à exploração dos sentimentos religiosos e a proibição de protestos religiosos organizados por partidos políticos)], ou quando o presidente, vice-presidente ou secretáriogeral faça qualquer pronunciamento escrito ou oral contrário a essas determinações. [...]'

Seção 103

'Quando se provar que um partido político tornou-se um centro de atividades contrárias às disposições das seções 78 a 88 ... da presente Lei, o partido será dissolvido pela Corte Constitucional'” (CEDH, p. 17-18, tradução livre)

Os dados que a Corte Constitucional mencionou em suporte à constatação de que o Refah Partisi teria se tornado um centro de atividades contrárias ao princípio do secularismo incluem uma fala de Erbakan na assembleia partidária de 10 de dezembro de 1993 em que ele teria exortado ao uso do véu islâmico em escolas e repartições públicas - uma manifestação religiosa que representaria uma forma de pressão sobre pessoas que não seguem essa prática. Além disso, segundo o tribunal turco, a pluralidade de sistemas jurídicos que Erbakan propunha não tinha relação com a liberdade contratual, como ele sustentava, mas, em vez disso, expressaria o objetivo de instalar um regime teocrático. A pluralidade de sistemas jurídicos dividiria o país em comunidades religiosas e cada indivíduo teria de escolher a qual delas pertenceria e de submeter-se às determinações desta, o que importaria em discriminação entre cidadãos turcos com base na religião e em risco para a unidade dos poderes legislativo e judicial. De mais a mais, o tribunal citou um discurso público de Şevki Yilmaz em que ele teria conclamado as pessoas à jihad e apoiado a adoção do direito islâmico, o que não impediu que o partido lançasse sua candidatura em eleições locais. Outros líderes partidários teriam se manifestado publicamente de modo semelhante, propondo um regime baseado na sharí'a ou incitando as pessoas ao ódio religioso. Por fim, a Corte Constitucional reportou-se a um decreto de 13 de janeiro de 1997 que reorganizou os horários de trabalho nos estabelecimentos públicos 
para permitir o jejum no período do Ramadã, o qual a Suprema Corte Administrativa anulou com base no princípio do secularismo (CEDH, 2003, p. 8-13).

Sob o ângulo jurídico-normativo, a Corte Constitucional declarou que a “Democracia é a antítese da sharī'a. [O] princípio [do secularismo], que é um sinal de responsabilidade cívica, foi o ímpeto que possibilitou à República da Turquia mover-se da umma [...] em direção à nação" (TURQUIA, 1998, apud CEDH, 2003, p. 13, tradução livre). Em conclusão, o tribunal considerou que a constituição e os instrumentos supranacionais de direitos humanos autorizavam a dissolução do partido político que perseguisse o objetivo de pôr fim à ordem democrática e que se valesse da liberdade de expressão para conclamar a ações destinadas a alcançar esses fins (CEDH, 2003, p. 14).

Em reação a esse julgamento, o Refah Partisi e três de seus integrantes (Necmettin Erbakan, Şevket Kazan e Ahmet Tekdal) apresentaram requerimentos contra a República da Turquia perante a Comissão Europeia de Direitos Humanos, alegando que a dissolução do partido pela Corte Constitucional teria violado o direito à liberdade de associação previsto no artigo 11 da Convenção Europeia de Direitos Humanos. ${ }^{96}$ Em 13 de fevereiro de 2003, o Tribunal Pleno da Corte Europeia de Direitos Humanos anunciou sua decisão de que não houve qualquer afronta à norma convencional.

Depreende-se do texto decisório que tanto as partes quanto a CEDH concordavam que a dissolução do partido configurou uma interferência no exercício do direito à liberdade de associação, de modo que a controvérsia consistia em saber se essa interferência justificar-se-ia, isto é, se encontraria previsão legal na ordem jurídica doméstica, se atenderia a um objetivo legítimo e se revelar-se-ia necessária em uma sociedade democrática.

No que tange ao primeiro critério, a Corte Europeia de Direitos Humanos afirma que o texto constitucional da Turquia e a lei sobre partidos políticos preveem claramente o poder da Corte Constitucional de dissolver partidos políticos que tenham se tornado centros de atividades contrárias ao secularismo. Destaca também que o Refah Partisi era um partido político grande, que contava com assessoria jurídica, e que Erbakan, Kazan e Tekdal eram políticos experientes, que participaram dos debates parlamentares sobre propostas de emenda à

\footnotetext{
${ }^{96}$ Convenção Europeia dos Direitos Humanos: "Artigo 11. Liberdade de reunião e de associação. 1. Qualquer pessoa tem direito à liberdade de reunião pacífica e à liberdade de associação, incluindo o direito de, com outrem, fundar e filiar-se em sindicatos para a defesa dos seus interesses. 2 . O exercício deste direito só pode ser objeto de restrições que, sendo previstas na lei, constituírem disposições necessárias, numa sociedade democrática, para a segurança nacional, a segurança pública, a defesa da ordem e a prevenção do crime, a proteção da saúde ou da moral, ou a proteção dos direitos e das liberdades de terceiros. O presente artigo não proíbe que sejam impostas restrições legítimas ao exercício destes direitos aos membros das forças armadas, da polícia ou da administração do Estado."
} 
constituição atinentes ao tema ao poder da Corte Constitucional de declarar que um partido teria se convertido em um centro de atividades anticonstitucionais, de modo que teriam a capacidade e o conhecimento necessários para prever o risco de dissolução do partido. Portanto, a medida era "prevista pelo direito" (CEDH, 2003, p. 23-24).

Além disso, a validade dessa interferência sobre o exercício do direito de associação dependia de que ela visasse a um propósito legítimo. O governo da Turquia afirmou que a medida pretendeu proteger a segurança nacional, a segurança pública, os direitos e liberdades fundamentais, assim como prevenir crimes. Os requerentes, por sua vez, alegaram que a razão subjacente à dissolução do Refah Partisi foi a ameaça que a política econômica do partido impunha aos interesses de grandes empresas e dos militares. ${ }^{97}$ Em relação isso, a Corte Europeia de Direitos Humanos considera que os requerentes não teriam conseguido demonstrar que a Corte Constitucional da Turquia teria dissolvido o partido por motivos diferentes daqueles que ela anunciou. Então, a decisão deste tribunal estaria em conformidade com os objetivos legítimos que o artigo 11 da Convenção Europeia enumera: "a proteção da segurança nacional e da segurança pública, a prevenção da desordem ou do crime e a proteção dos direitos e liberdades de outros" (CEDH, 2003, p. 24, tradução livre).

Em comparação a essas questões, a Corte Europeia de Direitos Humanos dedica-se mais profundamente à avaliação sobre a necessidade da medida em uma sociedade democrática. Ela reitera a jurisprudência de que a democracia é o único modelo que as normas convencionais contemplam e de que o papel do Estado em uma sociedade democrática é o de organizador neutro e imparcial das práticas religiosas, o que impõe a ele o dever de garantir a tolerância mútua entre grupos opositores. Para ela, "o Estado pode limitar a liberdade de manifestar uma religião, por exemplo vestindo um véu islâmico, se o exercício dessa liberdade colide com os objetivos de proteger os direitos e liberdades de outros, a ordem pública e a segurança pública" (CEDH, 2003, p. 29, tradução livre). Igualmente, pode impor a servidores públicos “o dever de abster-se de participar do movimento fundamentalista islâmico, cujo objetivo e plano de ação é causar a proeminência de regras religiosas" (CEDH, 2003, p. 30). Sustenta que um partido

\footnotetext{
${ }^{97}$ Historicamente, os militares são os guardiões do kemalismo e do projeto de modernização da sociedade na Turquia, o que explica os golpes de Estado que aconteceram nos momentos em que as reformas de Atatürk pareceram-lhes sob ameaça. Em fevereiro de 1997, o exército emitiu um ultimato ao governo, mencionando incidentes que configurariam atos contrários ao secularismo. No período subsequente, comandantes militares expuseram publicamente um conceito de defesa nacional que apontava o "anti-secularismo reacionário" como um inimigo interno mais perigoso do que adversários externos. Nesse contexto, em junho de 1997, Necmettin Erbakan e o governo do Refah Partisi tiveram de renunciar (GULALP, 1999) - um acontecimento que se tornou conhecido como "golpe pós-moderno" (AYDINLI, 2009, p. 585). Portanto, a alegação dos peticionantes em seu requerimento à Comissão Europeia de Direitos Humanos não é totalmente desprovida de suporte fático. A Corte, no entanto, entendeu por bem não discutir o contexto político na Turquia anterior à dissolução do partido.
} 
político pode propor mudanças nas estruturas constitucionais e legais, desde que o faça por meios legais e democráticos e de que as mudanças sejam elas próprias compatíveis com os princípios democráticos. Mesmo assim, assinala que medidas drásticas, tais como a dissolução de um partido político inteiro e a restrição dos direitos políticos por certo tempo, são admissíveis apenas em casos extremamente graves (CEDH, 2003, p. 31-32), em que se constate uma "necessidade social premente" (CEDH, 2003, p. 33).

Nesse quadro de referências, a Corte Europeia de Direitos Humanos afirma que o Refah Partisi representaria uma ameaça iminente para o regime democrático na Turquia. Pesquisas de opinião revelariam a perspectiva de que ele venceria pleitos futuros e indicariam que o partido tinha o potencial de assumir o poder sem as limitações inerentes a uma coalização: "Enquanto se pode considerar, no presente caso, que as políticas do Refah eram perigosas para os direitos e liberdades garantidos pela Convenção, as chances reais de que o Refah implementaria seu programa depois que conquistasse o poder tornaram esse perigo mais tangível e imediato" (CEDH, 2003, p. 35, tradução livre). Vê-se, assim, que a probabilidade de êxito eleitoral é uma premissa necessária para a constatação de que haveria uma necessidade social premente; porém, segundo Schilling (2003, p. 513), a CEDH não estende essa linha de raciocínio a outros casos sobre dissolução de partidos políticos.

De mais a mais, a Corte Europeia de Direitos Humanos considera que os atos e as declarações dos membros são imputáveis ao partido quando revelam seus objetivos e intenções. Os pronunciamentos de Necmettin Erbakan, em particular, são atribuíveis ao Refah Partisi, tendo em conta sua condição de presidente do partido. Os atos e os comentários dos integrantes, quando observados em conjunto, desvelariam o modelo de sociedade que o partido gostaria de implementar. O Refah Partisi não se distanciou das ideias que esses membros expressaram; pelo contrário, apresentou-os como candidatos a cargos importantes e absteve-se de iniciar procedimentos disciplinares contra eles antes do processo de dissolução (CEDH, 2003, p. 36). De acordo com Schilling, a Corte rompeu com seus precedentes ao desconsiderar a constituição partidária e as ações do Refah Partisi enquanto controlava o parlamento turco, enfatizando excessivamente posições de "extremistas" (SCHILLING; SPADA, 2003, p. 511). Para o autor, se a Corte Europeia tivesse examinado a constituição do partido, teria constatado que ele não defendia a imposição da sharì' $a$, mas o direito de cidadãos turcos matricularem seus filhos em escolas secundárias islâmicas, a permissão a mulheres de usarem o véu nas escolas e universidades públicas e a manutenção de fiéis muçulmanos nos quadros militares. Além disso, no período em que exerceu o governo, o Refah Partisi não apresentou projetos de lei tendentes à implementação do direito islâmico (SCHILLING; SPADA, 2003, p. 511-512). 
Em seguida, a Corte Europeia de Direitos Humanos passa a examinar se os fatos que a Corte Constitucional da Turquia assentou justificariam a decisão de dissolver o partido. No que tange à proposta que Necmettin Erbakan teria feito em duas ocasiões, no ano de $1993,{ }^{98}$ de instituir uma pluralidade de sistemas jurídicos no país, o Tribunal Pleno afirma que essa ideia contrariaria as normas convencionais e alude ao julgamento do órgão fracionário, conforme o qual a existência de uma pluralidade de sistemas jurídicos impediria que o Estado pudesse cumprir o papel de organizador neutro e imparcial das práticas de religiões diversas (na medida em que as pessoas teriam de obedecer às regras estáticas da comunidade religiosa, não àquelas que o Estado introduz na ordem jurídica visando ao cumprimento desse papel), como também infringiria o princípio da não-discriminação (CEDH, 2003, p. 37-38).

De igual modo, o Tribunal Pleno alinha-se ao entendimento do órgão fracionário de que a sharì'a seria incompatível com os princípios fundamentais da democracia. Considerando que o objetivo principal deste trabalho é avaliar os limites e as possibilidades do transconstitucionalismo entre o direito islâmico e outras ordens jurídicas da sociedade mundial, convém destacar o trecho em que a Corte Europeia de Direitos Humanos apresenta as razões por que a sharī'a não se coadunaria com a democracia:

"Como a Corte Constitucional, a Corte considera que a sharī'a, a qual reflete fielmente os dogmas e as regras divinas estipuladas pela religião, é estável e invariável. Princípios como o pluralismo na esfera política ou a evolução constante das liberdades públicas não têm lugar nela. A Corte nota que, quando lidas em conjunto, as declarações ofensivas, que contêm referências explícitas à introdução da sharī'a, são difíceis de reconciliar com os princípios fundamentais da democracia, tal como concebidos na Convenção como um todo. É difícil declarar o respeito pela democracia e pelos direitos humanos e ao mesmo tempo apoiar um regime baseado na sharì'a, que diverge claramente dos valores da Convenção, particularmente no que diz respeito ao direito penal e ao processo penal, a suas regras sobre o status jurídico das mulheres e ao modo como interfere em todas as esferas da vida privada e pública de acordo com preceitos religiosos. ... Na opinião da Corte, um partido político cujas ações parecem estar direcionadas a introduzir a sharī'a em um Estado-parte da Convenção dificilmente pode ser considerado uma associação obedecendo o ideal democrático que subjaz a toda a Convenção." (CEDH, 2003, p. 39-40, tradução livre)

Em seguida, o Tribunal Pleno enfrenta a alegação dos requerentes de que o órgão fracionário da Corte Europeia de Direitos Humanos teria se contradito ao afirmar

\footnotetext{
${ }^{98}$ Em sua petição à Comissão Europeia de Direitos Humanos, os requerentes apontaram que essas declarações teriam sido isoladas e desatualizadas. A proposta, segundo afirmaram, seria de introdução do sistema da civil law, no qual as pessoas tivessem a liberdade de aderir a contratos, o que não influenciaria o campo do direito público (CEDH, 2003, p. 25).
} 
simultaneamente que o Refah Partisi pretendia introduzir tanto uma pluralidade de sistemas jurídicos como também a sharī'a. ${ }^{99}$ Em resposta a essa alegação, o tribunal diz:

\begin{abstract}
"A Corte não é obrigada a expressar uma opinião em abstrato sobre as vantagens e desvantagens de uma pluralidade de sistemas jurídicos. Ela nota, para os propósitos deste caso, que - como a Corte Constitucional observou a política do Refah era a de aplicar algumas das regras de direito privado da sharī'a a uma parte grande da população na Turquia (a saber, muçulmanos), dentro da estrutura de uma pluralidade de sistemas jurídicos. Essa política vai além da liberdade de indivíduos de observarem os preceitos de sua religião, por exemplo organizando cerimônias de casamento religiosas antes ou depois de um casamento civil (uma prática comum na Turquia) e concedendo ao casamento religioso o efeito de um casamento civil [...]. Essa política do Refah está fora da esfera privada à qual o direito turco confina a religião e padece das mesmas contradições em relação ao sistema da Convenção que a introdução da sharía [...]. Seguindo essa linha de raciocínio, a Corte rejeita o argumento dos requerentes de que proibir uma pluralidade de sistemas de direito privado em nome do papel especial do secularismo na Turquia importaria em estabelecer discriminação contra muçulmanos que desejem viver suas vidas privadas de acordo com os preceitos de sua religião." (CEDH, 2003, p. 40-41, tradução livre).
\end{abstract}

A Corte Europeia de Direitos Humanos traça uma distinção entre a consciência individual e o campo do direito privado. Aquela constituiria a esfera da liberdade religiosa, enquanto este se ocuparia da organização e do funcionamento da sociedade como um todo. Portanto, a Turquia, como todos os Estados-parte, pode impedir a aplicação de regras de direito privado inspiradas na religião e prejudiciais à ordem pública e aos valores da Convenção (CEDH, 2003, p. 41).

Via de consequência, a Corte Europeia conclui que razões convincentes justificariam a dissolução do Refah Partisi e a perda temporária de direitos políticos de alguns de seus integrantes. Em face do contexto, a interferência estatal teria atendido a uma necessidade social premente e seria proporcional aos objetivos perseguidos. Por conseguinte, não teria havido violação ao artigo 11 da Convenção Europeia de Direitos Humanos. Finalmente, declara que a avaliação em separado das alegações de violação aos artigos $9^{\circ}, 10$, 14,17 e 18 seria desnecessária, ${ }^{100}$ porque elas diriam respeito aos mesmos fatos.

\footnotetext{
${ }^{99}$ No contexto do caso Refah Partisi et al. vs. Turquia, as ideias de instituir uma pluralidade de sistemas jurídicos e de adotar a sharī' $a$ articulam-se na proposta de reconhecimento da validade de atos jurídicos segundo prescrições do direito islâmico nas relações privadas de pessoas muçulmanas. Essa é uma possibilidade de interpretação do sentido que Erbakan queria dar à "liberdade contratual". Apesar disso, não é uma possibilidade de que Corte Europeia de Direitos Humanos tenha levado em consideração explicitamente.

${ }^{100}$ Esses dispositivos abordam a liberdade de pensamento, de consciência e de religião; a liberdade de expressão; a proibição à discriminação; a proibição ao abuso de direito; e, por fim, a limitação da aplicação de restrições aos direitos, respectivamente.
} 
Tendo em conta o interesse específico deste trabalho, cabe chamar a atenção para o voto concorrente do Juiz Kovler. Conquanto manifeste sua concordância com o resultado do julgamento, ele lamenta a superficialidade com que a Corte Europeia de Direitos Humanos abordou o conceito de pluralidade de sistemas jurídicos e a sharì'a:

\begin{abstract}
"Eu também lamento que a Corte, ao reproduzir as conclusões da Câmara, tenha perdido a oportunidade de analisar com mais detalhe o conceito de pluralidade de sistemas jurídicos, que está ligado àquele de pluralismo jurídico e está bem estabelecido na teoria e na prática jurídica antiga e moderna [...]. Não só a antropologia jurídica como também o direito constitucional moderno aceita que sob determinadas condições membros de minorias de todos os tipos podem ter mais de um tipo de status pessoal [...]. Certamente, esse pluralismo, que incide principalmente sobre a vida privada e familiar de um indivíduo, é limitado pelas exigências do interesse geral. Mas é obviamente mais difícil na prática encontrar um equilíbrio entre os interesses das comunidades em questão e os da sociedade civil como um todo do que rejeitar a própria ideia desse equilíbrio de antemão.

Esse comentário geral aplica-se também à avaliação a ser feita sobre a sharì 'a, a expressão jurídica de uma religião cujas tradições remontam a mais de mil anos e que tem seus pontos fixos de referência e seus excessos, como qualquer outro sistema complexo. De todo modo, a análise jurídica não deve caricaturar a poligamia (uma forma de organização familiar que existe em sociedades outras além dos povos muçulmanos) reduzindo-a a ... 'discriminação baseada no gênero das partes envolvidas"” (CEDH, 2003, p. 48-49, tradução livre).
\end{abstract}

No mês seguinte à dissolução do Refah Partisi, criou-se o Partido da Virtude (Fazilet Partisi ou Virtue Party, em inglês), ao qual se filiaram os prefeitos do partido extinto. Entre eles, Recep Tayyip Erdoğan, que era prefeito de Istanbul, condenado no ano seguinte a dez meses de prisão por incitação ao ódio religioso (KOÇAK, 2010, p. 251). A Corte Constitucional da Turquia dissolveu esse partido também, levando à criação do Partido da Justiça e Desenvolvimento (Adalet ve Kalkinma Partisi - AKP ou Justice and Development Party, em inglês) (KOÇAK, 2010, p. 252).

Erdoğan é o Presidente da Turquia, pelo AKP, atualmente. Em 15 de julho de 2016, ele sofreu uma tentativa de golpe militar, ${ }^{101}$ o que revela a permanência da tensão em torno do papel da religião na política e a relevância presente do caso Refah Partisi et al. vs. Turquia para a compreensão dos problemas constitucionais desse país.

101 Os meios de comunicação de massa divulgaram amplamente a tentativa malograda de golpe militar, praticamente ao mesmo tempo em que acontecia. Cf., por exemplo, ACKERMAN, Elliot. Atatürk versus Erdogan: Turkey's long struggle. In: The New Yorker. Disponível em: http://www.newyorker.com/news/newsdesk/ataturk-versus-erdogan-turkeys-long-struggle. Acesso em: 16 jul. 2016. 


\subsection{Pluralismo jurídico: os British Sharī’a Councils e o direito islâmico na jurisprudência norte-americana}

Neste tópico final do capítulo, pretende-se mostrar o lado oposto das interações entre direito islâmico e ordens jurídicas estrangeiras. Dois exemplos possibilitarão a avaliação sobre as possibilidades do transconstitucionalismo em países ocidentais quando eles se confrontam com a shari 'a no âmbito de sua jurisdição territorial. O primeiro exemplo refere-se a fóruns de solução de disputa na Inglaterra em que as normas de decisão baseiam-se na sharī'a. O segundo remete ao caso Awad v. Ziriax, em que a Corte de Apelações do Décimo Circuito dos Estados Unidos avaliou a constitucionalidade de uma proposta de emenda à constituição estadual que pretendia impedir que os juízes de Oklahoma levassem em consideração a sharī'a no julgamento dos casos que se apresentassem a eles.

A necessidade de reconstrução da Grã-Bretanha após a Segunda Guerra Mundial levou o governo a estimular a emigração nas ex-colônias, em especial do subcontinente indiano, em razão da demanda por mão-de-obra braçal disposta a trabalhar em troca de salários baixos. Houve uma onda de migração de muçulmanos. Entre 1948 e 1981, a legislação sobre migração, que anteriormente previa o trânsito mais ou menos livre de súditos britânicos entre os países que formavam o Império, começou a tornar-se cada vez mais restritiva, o que causou um influxo de migrantes de Bangladesh, do Quênia, de Marrocos e da Malásia que aproveitaram a política de unir cônjuges e familiares que já estivessem na Inglaterra. Nas décadas de 1970 e de 1980, cresceu a quantidade de mesquitas, de centros culturais islâmicos e de conselhos informais da sharī'a (BENSON, 2011, p. 22). Os British Sharī'a Councils cresceram a partir desses tribunais não-oficiais que emergiram nos bairros em que viviam grupos étnico-religiosos do Sul da Ásia.

Para Kristina Benson, "A tendência de muçulmanos autoidentificarem-se de acordo com a religião, ao invés da 'raça' ou da nacionalidade, não desaparece na diáspora, tampouco a inclinação a enxergar questões 'privadas' como fora do alcance do Estado e, por conseguinte, melhor enfrentadas por meio da sharī'a" (BENSON, 2011, p. 27, tradução livre). Por sua vez, Rebecca E. Maret sustenta que "Para muçulmanos vivendo no Reino Unido, a observância continuada dos princípios da sharī’a dá um senso de solidariedade, fortalecido pelas conexões com a cultura islâmica e com outros muçulmanos" (MARET, 2013, p. 258, tradução livre). Mesmo assim, a emergência de conselhos da sharī'a não se explica apenas a partir da necessidade de afirmação da identidade muçulmana: 
"Mulheres muçulmanas em particular têm razões para acreditar que sua propriedade é melhor protegida em conselhos da sharī'a do que em cortes inglesas ou galesas, visto que cortes inglesas e galesas só recentemente começaram a reconhecer acordos pré-nupciais, e, portanto, não eram obrigadas a reconhecer a eficácia de contratos matrimoniais muçulmanos na eventualidade de um divórcio. A falta de reconhecimento a esse contrato pode ser devastadora para mulheres, considerando que ele provê um veículo importante para a preservação da autonomia da mulher e para sua segurança financeira. Se um marido viola os termos do contrato, o casal pode ir à mediação para preservar o casamento, ou pode se divorciar. No caso em que o marido tenha de fato violado esses termos, ele deve pagar à mulher uma soma de dinheiro, chamada mehr [ou mahr, dependendo da transliteração]. O mehr é um presente dado pelo marido à sua noiva para simbolizar seu compromisso com ela, seu interesse em começar uma família, e sua capacidade de planejar para o futuro. Parte desse presente é dada ao tempo do casamento, e outra parte, ou mehr adiada, deve ser dada se o marido iniciar o divórcio, abandonar sua esposa ou morrer. [...] A falta de reconhecimento a esse contrato pode devastar mulheres muçulmanas financeiramente." (BENSON, 2011, p. 31, tradução livre)

Existem pelo menos oitenta e cinco conselhos ou tribunais de direito islâmico no Reino Unido atualmente (MARET, 2013, p. 255). Eles emitem fátuas, medeiam disputas familiares e decidem casos que envolvam casamento, divórcio, custódia de crianças ou herança segundo as previsões normativas da sharī'a (BENSON, 2011, p. 32).

Desde a promulgação da Lei de Arbitragem (Arbitration Act), que se deu em 1996, muçulmanos interpretaram que o texto legal permitiria que os conselhos da sharī'a atuassem como câmaras arbitrais, com autoridade para proferir decisões vinculantes para as partes e exequíveis nas cortes inglesas, desde que as partes consentissem voluntariamente com a jurisdição do conselho sobre o caso. Em 2007, um jurista muçulmano criou a Muslim Arbitration Court, afirmando que a Lei de Arbitragem garantir-lhe-ia o exercício da jurisdição.

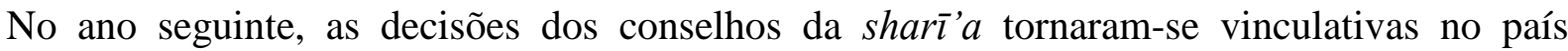
(BENSON, 2011, p. 32; MARET, 2013, p. 263). ${ }^{102}$

Esse reconhecimento causa controvérsia no Reino Unido, especialmente em função da preocupação com a discriminação de gênero nos British Sharia Councils. Recentemente, Theresa May, atual Primeira-Ministra da Inglaterra, anunciou que um painel de especialistas, liderado pela Professora Mona Siddiqui, da Universidade de Edimburgo, revisaria as práticas

\footnotetext{
${ }^{102}$ A pesquisa que subsidia este trabalho não logrou identificar com precisão o percurso procedimental ou jurídiconormativo que conduziu ao reconhecimento da validade e da eficácia das decisões dos British Sharì'a Councils. A hipótese mais provável, conforme se pode depreender dos artigos consultados, é a de que as cortes inglesas tenham adotado uma postura de deferência em relação às decisões dos conselhos da sharì’ $a$, destacando-se o julgamento do caso Halpern v. Halpern, em que a Corte de Apelação britânica afirmou que tribunais arbitrais podem decidir disputas conforme o direito que as partes escolherem (MARET, 2013, p. 264). Sob essa ótica, conselhos da sharì'a seriam uma espécie de fórum para resolução alternativa de disputas adequada às previsões da Lei da Arbitragem (Arbitration Act).
} 
dos conselhos da sharī'a para determinar se o direito islâmico é compatível com o direito inglês ou se estaria sendo utilizado para legitimar casamentos forçados e divórcios injustos para mulheres. May declarou que "Existe apenas um Estado de Direito [rule of law] em nosso país, o qual provê direitos e segurança para todos os cidadãos". ${ }^{103}$

Outro exemplo de como o problema da aplicabilidade do direito islâmico pode surgir para as ordens jurídicas estatais de países ocidentais é o caso Awad v. Ziriax, julgado pela Corte de Apelações para o Décimo Circuito dos Estados Unidos (United States Court of Appeals for the Tenth Circuit), ${ }^{104}$ em janeiro de 2012.

Os fatos relevantes desse caso remontam ao ano de 2010, quando o poder legislativo do estado de Oklahoma aprovou uma resolução conjunta para submeter a referendo a proposta de emenda à constituição estadual à qual se deu o nome de "Emenda Salve Nosso Estado" ("Save Our State Amendment"): 105 "Descrita como 'um ataque preventivo contra a chegada da sharī'a a Oklahoma' pelo deputado estadual Rex Duncan, seu autor originário" (GRUNERT, 2013, p. 701, tradução livre), a proposta de emenda constitucional visava a modificar um dispositivo para proibir juízes do estado de Oklahoma de levarem em consideração o direito internacional ou a sharí' a no julgamento de casos sob sua jurisdição:

"Os Tribunais instituídos na subseção A desta seção, quando em exercício de
sua autoridade judicial, devem defender e aderir ao direito tal como estipulado
na Constituição dos Estados Unidos, na Constituição de Oklahoma, no Código
dos Estados Unidos, nas regulações federais promulgadas de acordo com eles,
na common law consolidada, nas leis de Oklahoma e nas regras promulgadas
de acordo com elas e, se necessário, no direito de outro estado dos Estados
Unidos, contanto que o direito do outro estado não inclua a sharīa, na
elaboração de decisões judiciais. As cortes não devem olhar para preceitos
jurídicos de outras nações ou culturas. Especificamente, as cortes não devem

${ }^{103}$ Apud Sharia law review to focus on fairness to UK women - Theresa May. BBC, 26 maio 2016. Disponível em: $<$ http://www.bbc.com/news/uk-36388560>. Acesso: 31 jul. 2016.

${ }^{104}$ A Corte de Apelações para o Décimo Circuito dos EUA (United States Court of Appeals for the Tenth Circuit) exerce o segundo grau de jurisdição do poder judiciário federal nos Estados Unidos.

${ }^{105}$ Como a Corte de Apelações explica em sua decisão, um dos procedimentos de emenda previstos na constituição estadual de Oklahoma começa com a proposta de emenda em um dos ramos do poder legislativo. Se a maioria absoluta dos integrantes de cada uma das casas legislativas concordarem, o Secretário de Estado deve submetê-la à população para votação nas eleições gerais seguintes, exceto se dois terços dos membros de cada casa legislativa ordenarem uma eleição especial para essa finalidade. Além do texto da proposta, os legisladores elaboram o texto da cédula eleitoral que explica a proposta aos eleitores. A proposta de emenda e a cédula são submetidas ao Procurador-Geral (Attorney General), que deve avaliar a correção normativa e propor um texto para a cédula que atenda às normas jurídicas pertinentes (se necessário), antes do Secretário de Estado transmiti-las à Junta Eleitoral. Se a maioria dos eleitores votar a favor da adoção da emenda, ela se torna parte da constituição. A eficácia dessa votação depende da certificação do resultado da eleição pela Junta Eleitoral (Election Board), sem a qual não produz efeitos (ESTADOS UNIDOS, 2012, sem paginação).

Segundo a caracterização da Corde de Apelações para o Décimo Circuito, esse procedimento faz com que os legisladores sejam "framers" e os eleitores sejam "adopters" da emenda constitucional. 
considerar o direito internacional ou a sharī'a." (ESTADOS UNIDOS, 2012, sem paginação, itálico no original, tradução livre) ${ }^{106}$

A resolução previa que a cédula de voto explicaria a proposta de emenda ao eleitorado nos termos a seguir:

\begin{abstract}
"Essa medida emenda a Constituição Estadual. Ela modificaria uma seção que trata dos tribunais deste estado. Ela faria os tribunais fiarem-se ao direito federal e estadual ao decidirem casos. Ela proibiria tribunais de olharem para o direito internacional ou para a sharì'a quando decidirem casos.

A PROPOSTA DEVE SER APROVADA?" (ESTADOS UNIDOS, 2012, sem paginação, itálico no original, tradução livre) ${ }^{107}$
\end{abstract}

Para o Procurador-Geral de Oklahoma, a proposta para a cédula não atendia às leis aplicáveis, porque ela não conteria uma explicação adequada sobre os efeitos da emenda, considerando a ausência de um esclarecimento sobre o que é o direito internacional e a sharī'a. Ele preparou uma versão revisada, que dispôs:

\begin{abstract}
"Essa medida emenda a Constituição Estadual. Ela modifica uma seção que trata dos tribunais deste estado. Ela faz os tribunais fiarem-se ao direito federal e estadual ao decidirem casos. Ela proíbe tribunais de considerarem ou usarem o direito internacional. Ela proíbe tribunais de considerarem ou usarem a sharì'a.

Direito internacional também é conhecido como direito das nações. Ele trata da conduta de organizações internacionais e nações independentes, tais como países, estados e tribos. Ele trata de sua relação umas com as outras. Também trata de algumas de suas relações com pessoas.

O direito das nações é formado pelo consentimento geral de nações civilizadas. Fontes do direito internacional incluem também acordos internacionais, assim como tratados.

Sharì'a é o direito islâmico. Ela é baseada em duas fontes principais, o Corão e os ensinamentos de Maomé.

A PROPOSTA DEVE SER APROVADA?" (ESTADOS UNIDOS, 2012, sem paginação, itálico no original, tradução livre) ${ }^{108}$
\end{abstract}

\footnotetext{
106 Tendo em conta a importância da compreensão adequada do texto da proposta de emenda, convém transcrever a redação original, em inglês: "The Courts provided for in subsection A of this section, when exercising their judicial authority, shall uphold and adhere to the law as provided in the United States Constitution, the Oklahoma Constitution, the United States Code, federal regulations promulgated pursuant thereto, established common law, the Oklahoma Statutes and rules promulgated pursuant thereto, and if necessary the law of another state of the United States provided the law of the other state does not include Sharia Law, in making judicial decisions. The courts shall not look to the legal precepts of other nations or cultures. Specifically, the courts shall not consider international law or Sharia Law. The provisions of this subsection shall apply to all cases before the respective courts including, but not limited to, cases of first impression" (ESTADOS UNIDOS, 2012, sem paginação).

${ }^{107}$ Lê-se, no original: "This measure amends the State Constitution. It would change a section that deals with courts of this state. It would make courts rely on federal and state laws when deciding cases. It would forbid courts from looking at international law or Sharia Law when deciding cases. SHALL THE PROPOSAL BE APPROVED?" (ESTADOS UNIDOS, 2012, sem paginação).

${ }^{108}$ Lê-se, no original, em inglês: "This measure amends the State Constitution. It changes a section that deals with the courts of this state. It would amend Article 7, Section 1. It makes courts rely on federal and state law when
} 
Jeremy Grunert caracteriza essa definição de sharī'a como "simplista" e a tentativa de proibir o uso do direito internacional como "quase risível" (GRUNERT, 2013, p. 703). ${ }^{109}$ Apesar disso, cerca de setenta por cento dos eleitores aprovaram a proposta de emenda à constituição estadual nas eleições gerais de 02 de novembro de 2010. A modificação do texto constitucional efetivar-se-ia assim que a Junta Eleitoral certificasse o resultado das eleições (ESTADOS UNIDOS, 2012, sem paginação; GRUNERT, 2013, p. 703).

Dois dias após o pleito, Muneer Awad, um cidadão americano muçulmano residente em Oklahoma e diretor executivo da filial do Conselho sobre Relações Americanas-Islâmicas (Council on American-Islamic Relations) nesse estado, ajuizou uma ação contra os integrantes da Junta Eleitoral perante a Justiça Federal, a fim de impedir a certificação do resultado da votação popular. Awad pretendeu obter uma "preliminary injunction", ${ }^{110}$ alegando, em síntese, que a "Emenda Salve Nosso Estado" violaria seus direitos previstos na constituição federal dos Estados Unidos, em especial a separação entre Estado e religião e a liberdade religiosa, positivadas na Primeira Emenda. ${ }^{111}$ Aduziu que a implementação da emenda produziria um estigma negativo sobre ele e sobre todas as pessoas que praticam a religião muçulmana (inibindo a prática do Islã), obstaria que um tribunal homologasse seu testamento (que contém referências à $\operatorname{sharī’}^{\prime}$ ) e promoveria um envolvimento excessivo entre o governo e sua religião (ESTADOS UNIDOS, 2012, sem paginação).

Como diz Grunert (2013, p. 704, tradução livre), “As questões jurídicas em Awad v. Ziriax representam uma interseção curiosa de direitos constitucionais e regras religiosasculturais" - donde se extrai a relevância do caso para o objetivo geral declarado na introdução deste trabalho. Ele coloca a ordem jurídica estatal estadunidense em contato com o direito

\footnotetext{
deciding cases. It forbids courts from considering or using international law. It forbids courts from considering or using Sharia Law. International law is also known as the law of nations. It deals with the conduct of international organizations and independent nations, such as countries, states and tribes. It deals with their relationship with each other. It also deals with some of their relationships with persons. The law of nations is formed by the general assent of civilized nations. Sources of international law also include international agreements, as well as treaties. Sharia Law is Islamic law. It is based on two principal sources, the Koran and the teachings of Mohammed. SHALL THE PROPOSAL BE APPROVED?” (ESTADOS UNIDOS, 2012, sem paginação).

${ }^{109}$ Supõe-se que a exposição sobre a dogmática do direito islâmico no item 1.1 deste trabalho possibilite ao leitor ou à leitora alcançar a mesma conclusão que Grunert sobre a definição que o Procurador-Geral de Oklahoma apresentou para a sharì'a.

${ }^{110}$ Não há tradução óbvia para essa expressão. Em um exercício de comparação jurídica, o que mais se aproxima da preliminary injunction no direito brasileiro é a tutela inibitória, que é o provimento judicial destinado a impedir a prática, a continuação ou a repetição de atos ilícitos ou antijurídicos. Esse esclarecimento não deve conduzir à conclusão de que os conceitos seriam idênticos, porque a decisão do caso Awad v. Ziriax leva a crer que os pressupostos jurídico-normativos a que essas medidas devem atender são diferentes. Há também semelhanças notáveis entre a preliminary injunction e a tutela de urgência no Brasil.

${ }^{111}$ A esses dois componentes da Primeira Emenda à Constituição dos Estados Unidos, a doutrina estadunidense confere os nomes de Establishment Clause e Free Exercise Clause, respectivamente.
} 
islâmico e cria a oportunidade para o diálogo ou para a rejeição ao envolvimento. Por isso, passa-se a expor como os tribunais dos Estados Unidos decidiram-no.

A corte federal de primeira instância concedeu a preliminary injunction, sustentando que o requerente teria demonstrado a probabilidade de êxito quanto ao mérito de sua alegação sobre a Establishment Clause, pois a proposta de emenda inibe a religião e estimula o enredamento exacerbado entre o Estado e a religião. A juíza afirma que a sharī'a "não é direito", mas corresponde a tradições religiosas que variam entre muçulmanos, de modo que, para obedecerem à prescrição da emenda constitucional, os tribunais teriam de determinar o conteúdo da sharì'a e, por conseguinte, o conteúdo dos dogmas religiosos do requerente. Ademais, o texto da emenda singulariza especificamente a shar $\bar{\imath}$ ' $\mathrm{e}$ transmite uma mensagem de desaprovação à religião do requerente. A juíza diz também que os réus não apresentaram evidências de que a emenda atenderia a algum interesse relevante ou seria estritamente construída (“narrowly tailored") (ESTADOS UNIDOS, 2010, sem paginação).

Houve uma apelação para a Corte de Apelações para o Décimo Circuito dos Estados Unidos (United States Court of Appeals for the Tenth Circuit). Quanto a aspectos preliminares, o tribunal afirma que Muneer Awad tem legitimidade ativa ou standing para provocar a jurisdição com base na Establishment Clause, porque alega a ocorrência de prejuízos que vão além de um contato pessoal e indesejado com símbolos religiosos (o que, por si só, bastaria, segundo precedentes da corte). $\mathrm{O}$ autor sustenta que a emenda condena sua religião e expõe-no a tratamento desfavorável, impedindo que os tribunais considerem os preceitos jurídicos de sua religião, mas não os de outras. A existência dessa alegação de prejuízo efetivo mostra-se suficiente para atender a essa condição da ação.

A Corte de Apelações rejeita a alegação dos apelantes de que o caso não estaria "maduro" (ripe) para julgamento. ${ }^{112}$ Adverte que Awad questiona a validade da proposta de emenda em abstrato, o que não depende da apreciação de qualquer contexto fático específico. Enquanto os apelantes não sofreriam qualquer prejuízo com a apreciação imediata do caso, Awad amargaria um dano concreto e imediato correspondente à condenação de sua religião se a aprovação da emenda fosse certificada.

No mérito, a Corte de Apelações para o Décimo Circuito dedica-se primeiramente a definir qual o "teste" adequado para as circunstâncias do caso. Ela estabelece que o precedente

\footnotetext{
112 "A doutrina do amadurecimento impede a corte de decidir casos que são prematuros - demasiadamente especulativos ou remotos para autorizar a intervenção judicial. Um exemplo clássico seria o caso ajuizado para contestar uma lei criminal antes que uma persecução seja iniciada, em circunstâncias em que não se alega que a mera existência da lei produza danos efetivos" (STONE et al., 2009, p. 161, tradução livre).
} 
da Suprema Corte em Larson v. Valente proporciona o critério aplicável à avaliação do caso em comento: uma lei que discrimine entre religiões só é válida se for estritamente adequada para a promoção de um interesse premente. O "teste" previsto em Larson estende-se a Awad, porque este também aborda a existência de uma distinção explícita entre religiões: "a emenda de Oklahoma nomeia especificamente o alvo de sua discriminação. A única lei religiosa mencionada na emenda é a sharī' $a$, que é definida na SQ 755 em termos religiosos" (ESTADOS UNIDOS, 2012, sem paginação, tradução livre). ${ }^{113}$

Perfilhando essa linha de raciocínio, o tribunal tenta identificar algum interesse premente ou convincente (compelling interest) que pudesse justificar a emenda ao texto da constituição estadual. Embora reconheça que o interesse do estado de determinar o direito que se aplicará nas cortes estaduais reflete uma preocupação válida, assevera que essa declaração geral não é suficiente para estabelecer um interesse convincente, porque não identifica qualquer problema real que a emenda tentaria resolver. Tanto é assim que os apelantes "admitiram na audiência da preliminary injunction que não conheciam sequer um caso em que um tribunal de Oklahoma tenha aplicado a sharī'a ou usado os preceitos jurídicos de outras nações ou culturas, muito menos que tais aplicações ou usos teriam resultado em problemas concretos" (ESTADOS UNIDOS, 2012, sem paginação, tradução livre).

Adicionalmente, a Corte de Apelações registra que Awad demonstrou que sofreria danos irreparáveis caso lhe fosse negada a injunction e que essa ameaça prevalece sobre o prejuízo que os apelantes poderiam porventura sofrer em decorrência do provimento judicial. Finalmente, diz que a decisão não contraria o interesse público, pois, conquanto os tribunais devessem adotar uma postura de autocontenção frente à vontade que a população exprime por meio do processo eleitoral, existe um interesse público de mais longo prazo na prevenção de violações a direitos constitucionais.

Em conclusão, a Corte de Apelações para o Décimo Circuito dos Estados Unidos preservou o resultado do julgamento em primeira instância, concedendo a preliminary injunction e consequentemente barrando a certificação do resultado das eleições que tornaria eficaz a emenda à constituição estadual que pretendia excluir totalmente a possibilidade de um juiz considerar a sharī' $a$ ao proferir uma decisão. Embora essa não tenha sido a única iniciativa legislativa para bloquear qualquer função normativa do direito islâmico nos Estados Unidos (GRUNERT, 2013, p. 698-699), trata-se do único caso judicial de que se tem notícia por

113 “SQ 755" é a sigla de "State Question 755". Refere-se à pergunta que constou da cédula de voto e integra a proposta de emenda à constituição estadual. 
enquanto, com potencial para influenciar o debate público sobre a compatibilidade e o diálogo entre a ordem jurídica estatal nos EUA e a tradição jurídica islâmica. 


\section{TRANSCONSTITUCIONALISMO E DIREITO ISLÂMICO}

\subsection{Resistência e disposição ao envolvimento no aprendizado entre ordens jurídicas distintas}

No capítulo anterior, apresentaram-se casos em que o direito islâmico tenha entrado em contato com outras ordens jurídicas existentes na sociedade mundial. No primeiro, Zaheeruddin v. State, a Suprema Corte do Paquistão avaliou a constitucionalidade da Ordenação XX, a qual transformou o uso de símbolos religiosos islâmicos por integrantes da minoria Ahmadi em um tipo penal punível com prisão. Conforme visto, a Suprema Corte paquistanesa baseou-se em precedentes da Suprema Corte dos Estados Unidos para declarar a validade do texto normativo. No segundo caso, Mahmud Sami Muhammad 'Ali Wasil v. o Ministro da Educação (Caso n. 8 do Ano Judicial 17, de 18 de maio de 1996), a Suprema Corte Constitucional do Egito examinou a compatibilidade entre decisão do Ministro da Educação que vedou o uso do niqab pelas estudantes e o dispositivo constitucional que institui a sharì'a como a fonte principal da legislação no Egito. No terceiro, Refah Partisi et al. v. Turquia, a Corte Europeia de Direitos Humanos julgou se a dissolução de um partido político que supostamente pretendia a incorporação da sharī’a à ordem jurídica turca violaria a previsão normativa da liberdade de associação na Convenção Europeia de Direitos Humanos. Por fim, expuseram-se dois casos que mostram a face da discussão sobre a aplicabilidade do direito islâmico nos países do mundo ocidental: o caso dos British Sharī'a Councils, que são conselhos ou tribunais informais que concretizam o direito islâmico no Reino Unido; e o caso Awad v. Ziriax, em que a Corte de Apelações para o Décimo Circuito dos Estados Unidos discutiu a constitucionalidade de uma proposta de emenda à constituição estadual de Oklahoma que pretendia impedir que juízes desse estado levassem em consideração a sharī’a no exercício da jurisdição à luz das normas previstas na constituição federal desse país.

Esses casos refletem um problema relacionado à liberdade religiosa que se coloca para duas ordens jurídicas distintas ao mesmo tempo. ${ }^{114}$ Essa constatação permite discuti-los sob a ótica do transconstitucionalismo, porque compartilham seu elemento caracterizador principal: “O que caracteriza o transconstitucionalismo entre ordens jurídicas é, portanto, ser um constitucionalismo relativo a (soluções de) problemas jurídico-constitucionais que se apresentam simultaneamente a diversas ordens" (NEVES, 2009, p. 129).

\footnotetext{
114 Isso significa que ambas as ordens jurídicas pretendem submeter o âmbito do caso a seus processos comunicativos internos orientados de acordo com o código lícito/ilícito.
} 
Sob o ponto de vista descritivo, as operações transconstitucionais caracterizam-se pela reconstrução de sentido - "a incorporação recíproca de conteúdos implica uma releitura de sentido à luz da ordem receptora" (NEVES, 2009, p. 118). O caso-problema cria a oportunidade para a abertura normativa: os critérios internos de validade normativa não são abandonados, mas transformados por meio da inclusão de conteúdos no âmbito da norma jurídica durante o processo de concretização. Para Marcelo Neves, "a abertura normativa não quebra a consistência interna da cadeia de validação, antes serve a uma concretização jurídica normativamente adequada à pluralidade de ordens envolvidas" (NEVES, 2009, p. 127). Assim, "O transconstitucionalismo, como modelo de entrelaçamento que serve à racionalidade transversal entre ordens jurídicas diversas, abre-se a uma pluralidade de perspectivas para a solução de problemas constitucionais" (NEVES, 2009, p. 131), mas também reconhece a existência de ordens jurídicas sem disposição para o diálogo transconstitucional.

Segundo a tese do transconstitucionalismo, a fragmentação do problema constitucional que atravessa ordens jurídicas distintas requer a "conversação" - "a única forma capaz de dar e estruturar respostas adequadas aos problemas constitucionais que emergem fragmentariamente no contexto da sociedade mundial hodierna" (NEVES, 2009, p. 122). ${ }^{115}$ Então, sob o ângulo normativo, o transconstitucionalismo requer a reconstrução contínua da identidade constitucional. Faz-se necessária "a construção de mecanismos que sirvam à rearticulação da identidade mediante a observação da solução oferecida pela outra ordem para um determinado problema" (NEVES, 2009, p. 274), ou seja, a construção de "pontes de transição". O método do transconstitucionalismo baseia-se na contenção da ordem receptora, não como um fim em si mesmo, mas como postura que reflita a "capacidade de surpreender-se com os outros, na admissão de um futuro aberto, que não pode ser predefinido por nenhuma das ordens entrelaçadas no caso" (NEVES, 2009, p. 275). Em síntese:

\footnotetext{
"Em face da fragmentação, o método transconstitucional precisa desenvolverse na busca de 'pontes de transição' que possibilitem um relacionamento mais construtivo (ou menos destrutivo) entre ordens jurídicas, mediante a articulação pluridimensional de seus princípios e regras em face de problemas jurídico-constitucionais comuns, dependentes de soluções suportáveis para todas as ordens envolvidas" (NEVES, 2009, p. 277).
}

\footnotetext{
${ }^{115}$ No sentido preconizado pela tese do transconstitucionalismo, adequação significa "capacidade de possibilitar a convivência não destrutiva de diversos projetos e perspectivas, levando à legitimação dos procedimentos constitucionalmente estabelecidos, na medida em que esses servem para reorientar as expectativas em face do direito" (NEVES, 2009, p. 64).
} 
Nesse quadro de referências, a avaliação dos casos à luz do transconstitucionalismo incita duas perguntas diferentes. Em primeiro lugar, cabe discutir se a solução que a ordem receptora confere ao problema é exemplificativa de uma conversação transconstitucional ou, contrariamente, de uma rejeição ao envolvimento. Em segundo, nos casos em que se constate essa recusa, deve-se proceder à tentativa de identificar os mecanismos que inviabilizam o diálogo transconstitucional e que levam ao bloqueio recíproco.

Começando pelo caso Zaheeruddin v. State, observa-se que a Suprema Corte do Paquistão adotou precedentes da Suprema Corte dos Estados Unidos sobre a validade normativa de restrições legais a práticas religiosas para fundamentar sua asserção de que as atividades dos Ahmadis criariam riscos à segurança pública que justificariam a declaração de validade da Ordenação XX. Tendo em conta o modo como o argumento organiza-se no texto da decisão, expôs-se anteriormente que a jurisprudência estadunidense cumpre a função de garantia da passagem dos dados (existência de riscos à ordem pública) à conclusão (validade da lei que proíbe criminalmente que Ahmadis utilizem símbolos religiosos que seriam exclusivos do Islã).

De modo geral, os comentários à decisão da Suprema Corte do Paquistão destacam o uso incorreto dos precedentes dos Estados Unidos. M. Nadeem Ahmad Siddiq, por exemplo, sustenta que "O tribunal paquistanês tirou pronunciamentos judiciais do contexto e interpretou incorretamente o direito dos Estados Unidos. Um exame mais acurado desses casos em seu contexto completo mostra que as decisões estadunidenses contradizem as premissas básicas de Zaheeruddin" (SIDDIQ, 1995, p. 302, tradução livre). Diz, ainda, que a Suprema Corte do Paquistão deveria ter buscado precedentes mais recentes (SIDDIQ, 1995, p. 309).

Amjad M. Khan, por sua vez, trata as referências a precedentes estrangeiros como argumentos por analogia e dedica-se à identificação de problemas de consistência lógica na decisão do caso Zaheeruddin v. State. Segundo o autor, "Os argumentos por analogia do Justice Chaudhry demonstram a desatenção impressionante da corte à distinguibilidade relevante do direito constitucional e de marcas estadunidense" (KHAN, 2010, p. 509, tradução livre). Exemplificativamente, na referência que fez ao caso Cantwell v. Connecticut, Justice Chaudhry teria usado uma "regra garantidora da analogia" (analogy-warranting rule) problemática, porque teria desconsiderado a proteção ampla à liberdade religiosa que se afirmou nesse caso. A proibição à bigamia, que a Suprema Corte dos Estados Unidos considerou constitucional no julgamento de Reynolds $v$. United States, precedeu historicamente o surgimento dos mórmons, de modo que sua aplicação seria geral, não dirigida a um grupo específico, como acontece no 
caso dos Ahmadis (KHAN, 2010, p. 512-515). Falhas semelhantes atingiriam todos os argumentos por analogia que Justice Chaudhry usou na construção da norma de decisão. ${ }^{116}$

Essas abordagens observam quais padrões formais de argumentação a Suprema Corte do Paquistão utilizou no processo de concretização da norma jurídica e criticam a decisão de Zaheeruddin em função da qualidade técnica precária e da falta de uma linha argumentativa consistente com os precedentes que ela própria anuncia. Porém, as explicações que oferecem para o uso de conteúdos de ordens jurídicas estrangeiras são ambíguas. Siddiq lembra:

"Tribunais paquistaneses citam frequentemente as leis de outras jurisdições da common law, particularmente Estados Unidos, Grã-Bretanha, Canadá e Austrália. Considerando a herança 'anglo-islâmica' e pós-colonial da common law, o respeito da Suprema Corte do Paquistão pelo direito anglo-americano não é surpreendente." (SIDDIQ, 1995, p. 295, tradução livre)

No mesmo sentido, Tayyab Mahmud diz que o Poder Judiciário paquistanês trata precedentes e textos normativos das ordens jurídicas ligadas à tradição da common law como “autoridade persuasiva" (MAHMUD, 1995, p. 47), referindo-se ao artigo de H. Patrick que constrói esse conceito a partir da contraposição com o "direito vinculativo" (binding law) (GLENN, 1987, passim). Nesse contexto, a prática de citar precedentes e textos normativos estrangeiros seria consistente com características de Estados com história de colonialismo, ${ }^{117}$ em que a distinção entre o "doméstico" e o "estrangeiro" tornar-se-ia imprecisa - o que, entretanto, não se confunde com o transconstitucionalismo.

Não obstante a afirmação de que a Suprema Corte do Paquistão respeitaria o direito anglo-americano, Siddiq aduz em um trecho posterior de seu artigo sobre o caso Zaheeruddin que "o tribunal paquistanês aplicou de modo insincero jurisprudência dos Estados Unidos que tem mais de meio século. A confiança da corte em casos antigos como precedente foi apressada e autointeressada" (SIDDIQ, 1995, p. 301, tradução livre). Khan sustenta que Justice Chaudhry "empregou a comunicação transjudicial para insular a Suprema Corte do Paquistão de possíveis críticas estrangeiras à sua decisão" (KHAN, 2010, p. 522-523, tradução livre).

\footnotetext{
${ }^{116}$ Khan discute modelos diferentes de argumentação por analogia e avalia cada uma das referências a casos da jurisprudência estadunidense a partir daquele que lhe parece mais adequado. Não convém expor todas as falhas argumentativas que esse autor identifica ao fazer essa análise, pois, aqui, pretende-se apenas mostrar como estudos prévios abordaram o contato entre ordens jurídicas diferentes.

${ }^{117}$ Trata-se de uma hipótese plausível sob a ótica da tese do transconstitucionalismo: "Portanto, embora se possa admitir que, 'em Estados plurinacionais, com uma história de ocupação, colonialismo e/ou influência de outros, assim como em crescente interconexão com outros países, a fronteira entre 'estrangeiro' e 'doméstico', para conceitos considerados intangíveis como 'princípios jurídicos', sempre foi e está se tornando cada vez mais imprecisa', não se deve confundir o transconstitucionalismo com o simples 'transplante' de instituições jurídicas, nem vinculá-los a Estados mais frágeis na constelação internacional” (NEVES, 2009, p. 173).
} 
Há trechos do texto decisório que dariam suporte à asserção de que as referências a precedentes de ordens jurídicas estrangeiras são retóricas - no sentido pejorativo desta palavra. Em vez de promoverem um entrelaçamento das ordens jurídicas envolvidas, elas teriam por objetivo evitar críticas, visto que os critérios que o tribunal adota seriam idênticos àqueles dos países, como diz, "que alegam serem seculares e liberais, e não religiosos ou fundamentalistas" (PAQUISTÃO, 1993, sem paginação, tradução livre). Tayyab Mahmud chama a atenção para “o tom polêmico e o uso repetido pela Corte de perguntas retóricas" (MAHMUD, 1995, p. 50, tradução livre). ${ }^{118}$ Para Siddiq, os trechos em que Justice Chaudhry cita falas de Mirza Ghulam Ahmad sobre Maomé destinar-se-iam a despertar a antipatia de leitores ou de leitoras ocidentais em relação aos Ahmadis:

“A Corte paquistanesa também atribuiu as seguintes palavras a Mirza Ghulam
Ahmad: 'O Profeta Sagrado comia queijo feito por cristãos ao qual eles
adicionavam gordura de porco [que é proibida para muçulmanos].' [...] A
Corte paquistanesa não proveu uma referência para dar suporte a essa citação.
Com efeito, essa citação não existe nos escritos de Ahmad. Ela parece ser uma
tentativa de inflamar o mundo ocidental e cristão contra Ahmadis. A Corte
colocou em um voto judicial pronunciamentos não corroborados e fabricados
sem conceder aos Ahmadis uma oportunidade de defenderem-se contra eles.
Fazer citações não corroboradas não é próprio de uma corte suprema”
(SIDDIQ, 1995, p. 319 , tradução livre)

A ambiguidade a que se aludiu anteriormente consiste em assinalar a frequência com que os tribunais paquistaneses incorporam conteúdos advindos do direito estrangeiro às soluções que conferem a casos concretos e, ao mesmo tempo, apontar a falta de sinceridade com que se teria empregado os precedentes estadunidenses no processo de concretização da norma do caso Zaheeruddin. Isso sugere que há algo de particular a esse caso que tenha impedido o enredamento e levado ao bloqueio dos conteúdos da ordem jurídica dos Estados Unidos na solução do problema constitucional da liberdade religiosa: a sobreposição do código da religião (imanente/transcendente) ao código do direito (lícito/ilícito). ${ }^{119}$

\footnotetext{
${ }^{118} \mathrm{O}$ autor cita, como exemplo disso, a pergunta que já se transcreveu na exposição sobre o caso no item 2.1 deste trabalho: "Pode então qualquer um culpar um muçulmano caso ele perca controle de si mesmo ao ouvir, ler ou ver materiais blasfemos tais como produzidos por Mirza Sahib?” (PAQUISTÃO, 1993, sem paginação, tradução livre).

${ }^{119}$ Cabe mencionar o seguinte excerto da decisão como evidência disso: "É então claro que a constituição adotou as injunções do Islã tais como contidas no Corão e na sunna do Profeta Sagrado como o direito verdadeiro e efetivo. Nessa visão da matéria, as injunções do Islã tais como contidas no Corão e na sunna do Profeta Sagrado são agora direito positivo. O artigo 2-A tornou eficaz e operativa a soberania de Allah Todo-Poderoso e é em razão desse artigo que as determinações e princípios do direito, como incorporadas na Resolução de Objetivos, tornaramse eficazes e operativas. Portanto, toda lei humana deve agora conformar-se às injunções do Islã tais como contidas no Corão e na sunna do Profeta Sagrado. Portanto, até os direitos fundamentais previstos na constituição não podem violar as normas do Islã” (PAQUISTÃO, 1993, sem paginação, tradução livre).
} 
O transconstitucionalismo depende da disposição para ceder diante das perspectivas de outras ordens jurídicas (NEVES, 2009, p. 265). A decisão do caso Zaheeruddin v. State confirma a hipótese inicial de que a falta dessa disposição em casos sobre liberdade religiosa pode configurar, em situações extremas, uma espécie de alopoiese do direito, na medida em que o sistema jurídico perde capacidade de reprodução frente à religião. Apesar da roupagem aparente de transconstitucionalismo, a ausência de reflexão sobre a identidade constitucional revela que a Suprema Corte do Paquistão não se dispõe a uma autodesconstrução seguida pela reconstrução de sentidos normativos. O que explica essa rejeição ao envolvimento é o desprezo pelo outro - não existe uma esfera pública pluralista nem acesso generalizado aos processos constitucionais. A Suprema Corte do Paquistão encara o Islã como algo rígido e imutável, que, por conseguinte, não admite desvios que ameacem o dogma da religião. Ahmadis são o errado jurídico - desprezíveis, portanto ilegais.

Nesse quadro de referências, não se pode dizer que a referência a precedentes estrangeiros no texto da decisão corresponderia seja só retórica. ${ }^{120} \mathrm{O}$ fato de que a incorporação de conteúdos seja uma prática recorrente nas instituições do sistema jurídico no Paquistão impede que se afirme que a Suprema Corte adota uma postura nacionalista ou de isolamento absoluto em relação a ordens jurídicas diversas. Porém, o caso Zaheeruddin v. State mostra que, mesmo que possa ter havido disposição do Poder Judiciário paquistanês ao envolvimento com outras ordens jurídicas da sociedade mundial para a solução de questões jurídicas diferentes, quando o problema da liberdade religiosa apresenta-se de modo relevante para o direito islâmico, o mesmo comportamento não se verifica.

Situação diversa é aquela que se constata na decisão do caso Mahmud Sami Muhammad 'Ali Wasil v. o Ministro da Educação (Caso n. 8 do Ano Judicial 17, de 18 de maio de 1996), que, para Mohamed A. Arafa, “é uma decisão histórica da Suprema Corte Constitucional do Egito e representa uma das determinações judiciais mais relevantes de um remédio estrutural para a interpretação do artigo $2^{\circ}$ da constituição do Egito de 2014" (ARAFA, 2016, p. 1, tradução livre). ${ }^{121}$

Para Kilian Bälz, a decisão da Suprema Corte Constitucional do Egito sobre o uso do véu nas escolas públicas ilustra "a luta para defender a autonomia da ordem jurídica secular"

\footnotetext{
${ }^{120}$ Vale repetir que a palavra "retórica", nesse contexto, assume o sentido depreciativo da linguagem cotidiana, distante da corrente filosófica que remonta a Aristóteles e que tenta desenvolvê-la sob a forma da razão prática. ${ }^{121}$ Comparando-se o artigo $2^{\circ}$ da constituição egípcia de 1971, com a redação que a emenda de 1980 conferiu-lhe, com o texto constitucional de 2014, constata-se uma diferença singela, cujas implicações jurídico-normativas, se existirem, não são claras. Enquanto aquele previa que a sharī’a é a fonte principal da legislação, este estabelece que "os princípios da sharì'a islâmica" são a fonte principal da legislação.
} 
(BÄLZ, 1999, p. 233, tradução livre). Esse autor sustenta que a abordagem do tribunal corresponde a uma reconstrução interna das regras do direito islâmico que viabiliza a autonomia da ordem jurídica secular em relação à sharī'a. Na medida em que reserva ao governante o poder de determinar o direito substantivo e que afirma a própria autoridade para interpretar o artigo $2^{\circ}$ da constituição, a Suprema Corte Constitucional do Egito garante o fechamento operativo da ordem jurídica estatal. Ao mesmo tempo, entrelaça a solução do problema ao direito islâmico, incorporando os conteúdos deste ao âmbito da norma de decisão. Bälz conclui:

\begin{abstract}
"O direito islâmico e a legislação estatal são duas ordens jurídicas que permanecem autônomas. Sempre que regras do direito islâmico são 'incorporadas' à ordem do direito secular, elas são uma construção interna da ordem do direito secular. Sob o artigo $2^{\circ}$ da constituição egípcia, referências ao direito islâmico por meio de tribunais seculares não são nada além de uma estratégia usada pela ordem do direito secular para manter sua autonomia. Referências ao direito islâmico servem como um meio para legitimar a legislação estatal. No entanto, o direito islâmico não constitui um corpo de "normas supralegais" pressupostas, que são inacessíveis à interpretação mundana, porque é o privilégio da legislatura codificar o direito islâmico de uma maneira que corresponda às exigências do 'tempo e região' . [...] a questão da validade normativa em geral e da constitucionalidade de leis em particular é decidida exclusivamente pela ordem do direito secular de acordo com seus próprios critérios. Essa autorreferência, e não o fenômeno da 'legislação', constitui a positividade do direito, isto é, que 'a validade normativa não pode ser trazida de fora; ela pode ser somente produzida no interior do direito"” (BÄLZ, 1999, p. 243, tradução livre).
\end{abstract}

Nessa ordem de ideias, a crítica de Lombardi e Brown a Killian Bälz é mal dirigida. Em nenhum momento este autor afirma que a Suprema Corte Constitucional do Egito teria realizado um exercício cínico de cobrir a falta de justificativa islâmica plausível para o resultado que proclama por meio do uso impróprio de termos técnicos da tradição jurídica islâmica (LOMBARDI; BROWN, 2006, p. 431). Quando diz que o tribunal faz referência ao direito islâmico como uma estratégia de preservação da autonomia da ordem jurídica estatal secular, Bälz não utiliza a palavra "estratégia" como um sinônimo de um agir orientado pelo êxito destituído de pretensão de validade normativa. ${ }^{122}$ Ele mostra como e por que a Suprema Corte Constitucional rearticulou internamente conteúdos de sentido do direito islâmico e da própria ordem jurídica egípcia a fim de alcançar uma solução para o caso-problema que fosse suportável tanto para o direito islâmico quanto para a ordem estatal do país.

\footnotetext{
${ }^{122}$ Em outras palavras, não se trata do agir estratégico descrito na teoria discursiva de Jürgen Habermas (2012a, p. 196 ss.) que se pudesse contrapor a um agir comunicativo orientado pelo consenso.
} 
Portanto, a conclusão de Bälz é compatível com a asserção de Lombardi e Brown no sentido de que a Suprema Corte Constitucional do Egito "usou a tradição de um modo criativo para criar uma abordagem nova do pensamento jurídico islâmico no contexto do pensamento constitucional" (LOMBARDI; BROWN, 2006, p. 432, tradução livre). A decisão do caso Muhammad 'Ali Wasil v. o Ministro da Educação é exemplificativa do transconstitucionalismo, na medida em que exibe um esforço de releitura da ordem receptora e promove o convívio entre ordens jurídicas que partem de experiências históricas diversas.

Isso não significa que a tese do transconstitucionalismo ou este trabalho recomendem a universalização do padrão argumentativo que a Suprema Corte Constitucional do Egito usou no processo de concretização da norma de decisão desse caso para todos os países do mundo islâmico ou para todos os casos que se apresentem de modo relevante para o direito islâmico e para determinada ordem jurídica estatal simultaneamente, mas ajudam a mostrar que a abertura normativa contribui para amenizar os riscos de inadequação social do direito e de anomia também no contexto dessas sociedades.

O caso Refah Partisi et al. v. Turquia talvez seja aquele que ilustre melhor esses riscos. De acordo com Lisbet Christoffersen, "Quando a CEDH no caso Refah Partisi decide contra o partido em razão de seu 'plano de instituir uma pluralidade de sistemas jurídicos', é o sistema millet que a corte considera incompatível com o sistema da Convenção" (CHRISTOFFERSEN, 2010, p. 66, tradução livre). ${ }^{123}$ Para a autora, “A corte estava realmente buscando rejeitar o sistema millet a fim de bloquear definitivamente qualquer tentativa de reintroduzir um sistema jurídico baseado na religião na Europa" (CHRISTOFFERSEN, 2010, p. 66, tradução livre). O direito europeu dos direitos humanos confina o exercício da liberdade religiosa à esfera de autonomia privada dos indivíduos e proíbe que a religião influencie a regulação da vida social: "Não há qualquer dúvida de que a Europa não está preparada para permitir que grupos religiosos decidam a respeito do direito de família para seus aderentes" (CHRISTOFFERSEN, 2010, p. 68, tradução livre).

Na decisão da Corte Europeia de Direitos Humanos, observa-se o unilateralismo e a incapacidade para a conversação constitucional. A atuação do tribunal no caso Refah Partisi revela a indisposição para o intercâmbio em encontros futuros e bloqueia o direito islâmico

\footnotetext{
${ }^{123}$ No Império Otomano, deixava-se a administração da justiça a cargo das comunidades religiosas, que cumpriam a função de normatizar matérias relacionadas ao direito de família ou das sucessões, por exemplo, bem como a de decidir problemas jurídicos. Desse modo, "O direito privado dos súditos do império dependia da comunidade à qual eles pertenciam. Judeus seguiam o direito hebraico, ortodoxos seguram o direito canônico ortodoxo, cristãos assírios seu sistema jurídico e muçulmanos, a sharì'a" (CHRISTOFFERSEN, 2010, p. 65, tradução livre). A esse sistema dá-se o nome de "millet".
} 
como ordem jurídica concorrente. Ela nega de antemão a possibilidade de que o direito islâmico possa contribuir para resolver problemas constitucionais comuns. Por isso, não oferece soluções complexamente adequadas à sociedade - como a refundação de partidos islamitas na Turquia após a dissolução do Refah Partisi permite afirmar. A desconfiança em relação à sharī’a constitui um empecilho à construção de "pontes de transição": "na negação do reconhecimento do outro, a desconfiança expande-se de tal maneira que impede a construção de interações fundadas na dupla contingência" (NEVES, 2009, p. 272).

Contrariamente ao transconstitucionalismo, para o qual "um caminho equivocado seria negar a abertura cognitiva das respectivas ordens para os sistemas sociais com o qual [sic] se encontram confrontadas, o que impediria o surgimento da transversalidade constitucional" (NEVES, 2009, p. 237), a decisão da Corte Europeia de Direitos Humanos no caso Refah Partisi exclui a religião completamente da esfera pública. Ela é incompatível com o modelo do Estado Democrático de Direito subjacente à tese do transconstitucionalismo, que depende da existência de uma esfera pública pluralista, ou seja, "um campo complexo de tensão entre direito e política como sistemas acoplados estruturalmente pela Constituição, de um lado, e mundo da vida e outros subsistemas funcionalmente diferenciados da sociedade (economia, ciência, religião etc.) de outro" (NEVES, 2012, p. 133), porque impede que interesses, valores e discursos ligados à religião possam pretender se generalizar politicamente por meio dos procedimentos constitucionais de intermediação dos conflitos.

Posto que este seja um passo argumentativo ambicioso (tendo em conta os limites do objeto deste trabalho), o âmbito do caso Refah Partisi e a avaliação da decisão à luz do transconstitucionalismo ajudam a entender a persistência de determinados problemas constitucionais na Turquia, sobretudo a quantidade de golpes militares desde a fundação da república e a tensão permanente entre o secularismo assertivo de Atatürk e a pretensão de um papel mais relevante para o Islã na organização social. Em vez de erigir procedimentos estáveis de absorção do dissenso, a Turquia tem reiteradamente tentado excluí-lo da arena política, notadamente por meio da dissolução de partidos políticos. A tentativa de insular o sistema jurídico das perspectivas religiosas que existem em seu ambiente prejudica "a capacidade de reprodução internamente consistente e externamente adequada" (NEVES, 2009, p. 46), ensejando crises constitucionais. Essas considerações não pretendem estabelecer um nexo causal absoluto entre o entendimento da Corte Constitucional turca e da Corte Europeia de Direitos Humanos sobre a incompatibilidade da sharī'a com a democracia constitucional e os desafios constitucionais desse país, mas apontar um dos fatores que podem contribuir para perpetuar problemas constitucionais graves. 
O reconhecimento dos British Sharī'a Councils no Reino Unido, a partir de uma interpretação inovadora da Lei de Arbitragem (Arbitration Act), de 1996, assim como a decisão da Corte de Apelações para o Décimo Circuito dos Estados Unidos no caso Awad v. Ziriax oferecem um contraponto para o julgamento de Refah Partisi et al. v. Turquia, porque, conquanto não se engajem em uma investigação profunda sobre a sharī'a e o direito islâmico, admitem um futuro aberto, "que não pode ser predefinido por nenhuma das ordens entrelaçadas no caso" (NEVES, 2009, p. 275). Esses dois exemplos alinham-se ao transconstitucionalismo, pois reconhecem o potencial de surgimento de casos-problema que exijam respostas adequadas tanto para a ordem jurídica estatal britânica ou estadunidense quanto para o direito islâmico. Nesse sentido, são diametralmente opostos à decisão do caso Refah Partisi: em vez de excluírem prima facie as regras da sharī’a de qualquer consideração, preservam a abertura normativa das ordens para o aprendizado recíproco.

Há resistência a esse envolvimento: o pronunciamento de Theresa May no Reino Unido e as propostas legislativas de proibição da sharī'a nos Estados Unidos mostram que o transconstitucionalismo com o direito islâmico está sob a ameaça constante da desconfiança em relação a essa ordem. Nos EUA, costuma-se citar um caso de Nova Jersey em que o juiz negou o pedido de medidas protetivas para uma mulher que vinha sendo agredida pelo marido muçulmano sob a justificativa de que ele não estaria agindo com intenção criminal ou dolo, dado que os preceitos religiosos do Islã permitiriam o estupro da própria esposa (GRUNERT, 2013, p. 726; KIM, 2014, p. 287-288), um exemplo que justificaria a postura de desconfiança em relação ao direito islâmico. Porém, a Corte de Apelação reformou essa decisão (GRUNERT, 2013, p. 726). Por isso, o exemplo não basta para refutar a pretensão normativa do transconstitucionalismo como modelo de entrelaçamento entre ordens jurídicas.

\subsection{A modernidade nos países do mundo islâmico e a proposta de um constitucionalismo especificamente islâmico}

No primeiro capítulo, viu-se que, durante a maior parte da história, o direito islâmico desenvolveu-se paralelamente ao exercício do governo das comunidades muçulmanas. A sharī'a reconhece a autoridade do governante ou detentor do poder coercitivo (wali al-amr), por meio da doutrina da siyāsa shar 'iyya. Este, em contrapartida, permite que a sharī'a funcione nos campos do conhecimento jurídico, da educação e da administração da justiça. Segundo Nathan J. Brown, “Esse esquema implicou limitações práticas na autoridade do governante, mas não em qualquer forma constitucional: ele se baseava não em princípios fundamentais 
explícitos e bem articulados, mas na deferência implícita entre governantes e instituições baseadas na sharī'a" (BROWN, 2002, p. 163, tradução livre).

No entanto, a partir do Século XIX, inicia-se um processo de modernização que desloca a autoridade de criação do direito dos fuqahā para os governantes. Esse processo está intimamente ligado ao declínio do Império Otomano: as derrotas militares sucessivas e a necessidade de obtenção de crédito externo levaram a uma série de reformas conhecidas conjuntamente como Tanzimat, entre 1839 e 1908, que incluíram a codificação da doutrina da escola hanifita em um Código Civil (Mecelle) e a outorga de um texto constitucional que seguia o modelo monárquico belga (BROWN, 2002, p. 21; FELDMAN, 2008, p. 60). ${ }^{124}$ Além disso, extinguiu-se o sistema de justiça privado e criaram-se instituições anteriormente desconhecidas, como cortes mistas para o julgamento de disputas em matéria comercial. "Tudo isso significou que boa parte da atividade jurídica e judicial nas províncias centrais do Império Otomano foi removida do escopo da sharì'a, e estava sendo exercida em cortes nas quais aqueles com treinamento jurídico tradicional não podiam atuar” (WATT, 2013, p. 36, tradução livre).

Assim, a recepção de instituições modernas deu-se no contexto de superioridade militar e econômica externa ou, no caso de países do mundo islâmico fora do Império Otomano, da dominação colonial estrangeira. Entretanto, a resistência doméstica à imposição de inovações institucionais fez com que essa uma recepção acontecesse de modo incompleto. "Essa adoção parcial de instituições ocidentais conduziu a estruturas estatais de modo geral altamente ineficientes e frequentemente repressivas na maior parte do mundo em desenvolvimento" (AFSAH, 2008, p. 275-276, tradução livre).

Ebrahim Afsah explica que esse processo acelerado e imposto de modernização da ordem jurídica rompeu a validade tradicional do direito islâmico e dos regulamentos administrativos baseados na siyāsa shar iyya e produziu anomia - ou seja, incapacidade de coordenação por meio de ordens legítimas (HABERMAS, 2012b, p. 257):

"A qualidade irruptiva do processo de modernização que inevitavelmente
destrói os mecanismos ordenadores sociais e sistemas sociais existentes
(Lebensordnungen) desafia não só os modos de vida tradicionais, mas,
principalmente, identidades e sistemas normativos. Ela implica perda
significativa da autonomia individual e coletiva sob o impacto de forças

${ }^{124}$ Para Wael B. Hallaq, o fator principal para o fim da sharì' $a$ foi a criação de Estado-nações: “A morte da sharì'a foi iniciada pela internalização material do conceito de nacionalismo nos países muçulmanos, principalmente pela criação de Estado-nações. Essa transformação no papel do Estado é talvez o fato mais crucial acerca das assim chamadas reformas jurídicas. Enquanto o governante tradicional considerava a si mesmo submetido ao direito e deixava a autoridade e as funções judicial e legislativa para os ulemás, o Estado moderno reverteu esse princípio, assumindo assim a autoridade que ditava o que é o direito e o que não é" (HALLAQ, 2004, sem paginação, tradução livre). 
externas incompreensíveis (Fremdbestimmtheit) e causa, portanto, forte ressentimento como uma ameaça às definições individuais e coletivas de si mesmo [definition of the self]. Durkheim usava o termo 'anomia' para descrever essa condição de alienação e falta de motivação caracterizada pelo enfraquecimento das normas estabelecidas em uma sociedade que esteja passando por mudanças econômicas e sociais consideráveis, especialmente quando valores tradicionais que continuam a ser amplamente professados estão cada vez mais em descompasso com a realidade socioeconômica alterada, apresentando um ideal inatingível na vida real.” (AFSAH, 2008, p. 263-264, tradução livre)

No Século XX, intelectuais que não tinham vínculos com os centros tradicionais de ensino islâmico iniciaram um movimento de crítica ao distanciamento acentuado das ordens nacionais em relação ao direito islâmico, ao mesmo tempo em que condenavam a rigidez excessiva do ensino jurídico islâmico tradicional. Eles tentaram desenvolver uma ordem jurídica mais autêntica, em dois sentidos: "Primeiro, ela não seria baseada simplesmente nos modelos ocidentais, mas também na herança islâmica da região. Segundo, ela removeria os acréscimos e a rigidez de séculos de estudo jurídico abstrato e buscaria a gama de pensamento jurídico enterrada há muito por ulemás obscurantistas” (BROWN, 2002, p. 165, tradução livre). Nesse contexto, surgem tentativas de recuperação de elementos da tradição jurídica islâmica para a constituição de um constitucionalismo propriamente islâmico. ${ }^{125}$ Para Ebrahim Afsah, "A necessidade psicológica de reafirmar o controle e a agência sobre a mudança social explica o apelo popular das demandas pela reintrodução do direito islâmico. Em parte esse apelo remonta ao papel histórico do direito religioso como uma linguagem de justiça vis-à-vis regimes autocráticos" (AFSAH, 2008, p. 294, tradução livre).

Entretanto, os escritos sobre o constitucionalismo desde uma perspectiva islâmica são ambivalentes: ao mesmo tempo em que afirmam a relevância atual do direito islâmico para a integração social nesses países, também contestam boa parte da tradição, expondo-se a críticas de ambos os lados. Nathan J. Brown descreve essa dicotomia com precisão:

\footnotetext{
${ }^{125}$ Entre os elementos mais destacados da tradição jurídica islâmica para a construção de um constitucionalismo autêntico está a shūrā ou consulta, a qual, como se viu anteriormente (cf. nota de rodapé n. ${ }^{\circ}$ 44), tem sede corânica. A shūrā, como ideal de governo representativo, para o constitucionalismo islâmico emergente deve vincular o governante (BROWN, 2002, p. 172; EL FADL, 2012, p. 49). Wael B. Hallaq, por sua vez, entende que a solução para países sunitas perpassa a incorporação dos estudiosos religiosos à burocracia estatal: "O Estado deve recriar as condições necessárias para uma versão moderna do direito islâmico a ser construída e a evoluir grandemente por si mesma. Ele deve sustentar financeiramente instituições religiosas, especialmente faculdades de sharī'a; ele deve instalar a hierarquia religiosa na respectiva hierarquia social e política de modo a possibilitar que a profissão jurídica sinta e reflita as preocupações sociais em todos os níveis; ele deve ser capaz de dar a essa profissão jurídica uma moldura livre para determinar o que o direito é; e finalmente deve respeitar seu veredito. Mas nada disso pode ser obtido sem uma organização política genuinamente islâmica" (HALLAQ, 2004, sem paginação, tradução livre). O Irã é o único país a ter implementado uma solução autêntica, baseada na teoria da autoridade do jurista (velāyat-e faqīh), do imã Khomeini.
} 
"Essa ambivalência não deve surpreender, porque emana de um impasse difícil para pretensos constitucionalistas. Afirmar a natureza constitucionalista do Islã requer o estabelecimento de regras firmes e bem definidas para o exercício do governo. Essas regras não podem ser facilmente identificadas no pensamento político islâmico tradicional. É possível - como os constitucionalistas fizeram - desenvolver tais regras, mas isso exige que eles se engajem em um empreendimento que não é parte do pensamento jurídico islâmico tradicional. Para os críticos tradicionalistas da direita, a aplicação da sharī'a envolve a adoção simples de regras conhecidas. Para os críticos com mentalidade mais liberal da esquerda, a aplicação da sharì' $a$ envolve apenas a aceitação de princípios gerais e declarações inquestionáveis. Os constitucionalistas islâmicos ficam presos no meio. Sua proposta inflexível de aplicação da sharì'a é acompanhada por uma exortação à redefinição abrangente dos princípios básicos da sharī' $a$; tanto para tradicionalistas como para liberais, isso é dar um passo em direção ao desconhecido. Enaltecer a sharì'a pelos limites firmes que ela coloca para governantes parece ser uma alegação estranha daqueles que enfatizam simultaneamente sua flexibilidade. Com efeito, ela deixa constitucionalistas abertos à denúncia de insinceridade por ambos os lados. Tradicionalistas podem denunciar que constitucionalistas usam o Islã mas não o entendem; para liberais, os constitucionalistas buscam disfarçar o clamor por um governo islâmico em uma aparência menos ameaçadora." (BROWN, 2002, p. 177, tradução livre)

Outra dificuldade para o desenvolvimento de um constitucionalismo islâmico consiste no fato de que que a tradição jurídica não oferece procedimentos capazes de intermediar o dissenso conteudístico em sociedades cada vez mais complexas. Tratando-se de uma ordem religiosa, a sharī'a contém previsões normativas de direito substancial, mas pouco consenso procedimental. Devido a uma especialização incompleta do direito islâmico clássico, a sharī'a assemelha-se a uma concepção jusnaturalista: "o mutável permanece ainda subordinado ao imutável: o direito positivo só é válido enquanto se conforma ao direito natural inalterável" (NEVES, 2012, p. 23). Isso se revela, por exemplo, na hierarquia entre fontes sagradas e humanas no usūl al-fiqh. Sob outra perspectiva, pode-se dizer que, na tradição islâmica - diferente, repita-se, dos países do mundo islâmico contemporâneo -, cultura e sociedade não eram suficientemente diferenciadas estruturalmente, tendo em conta que as instituições não se separam de uma cosmovisão. ${ }^{126}$

Portanto, de um lado, a imposição agressiva de instituições modernas a sociedades em que remanescem particularismos étnicos ou religiosos e em que os elementos estruturais do mundo da vida e as pretensões de validade não se diferenciam completa e inequivocamente tende a provocar anomia. ${ }^{127}$ De outro, o direito islâmico não atende às exigências funcionais da

\footnotetext{
${ }^{126}$ Sobre a diferenciação funcional entre cultura e sociedade, cf. HABERMAS (2012b, p. 264-265).

${ }^{127}$ Com essa afirmação, não se pretende reduzir a sociedade à religião nem menosprezar a importância da oposição secular às tendências islamitas nos países do mundo islâmico, incorrendo no erro do essencialismo para o qual se
} 
sociedade mundial, na medida em que se mostra incapaz de compreender e reduzir a complexidade por meio de um consenso procedimental que preserve uma esfera pública pluralista e ao mesmo tempo legitime os resultados procedimentais eventuais no interior dos sistemas jurídico e político. Tanto o transplante da ordem e das instituições jurídicas dos países da modernidade central quanto a recuperação do direito islâmico clássico não conseguem combinar a necessidade de consistência com a adequação social do direito.

Em razão disso, o transconstitucionalismo, como modelo de entrelaçamento de ordens jurídicas, oferece um método promissor para lidar com os problemas constitucionais nos países do mundo islâmico: "embora haja ordens jurídicas que estão à margem do transconstitucionalismo, esse não pode excluir o desenvolvimento de institutos que possam levar a uma relação construtiva de aprendizado e intercâmbio" (NEVES, 2009, p. 130).

Exemplificativamente, Kilian Bälz caracteriza a relação entre a ordem jurídica estatal egípcia e o direito islâmico como "um conflito inter-sistêmico entre dois sistemas operativamente fechados que são radicalmente autônomos" (BÄLZ, 1995, p. 39, tradução livre). ${ }^{128}$ A positivação do direito a partir da edição de textos legislativos no Século XIX teria dado lugar ao pluralismo jurídico, definido como "uma multiplicidade de processos comunicativos diversos que observam a ação social sob o código binário lícito/ilícito" (TEUBNER, 1992, p. 1451, tradução livre). Nesse contexto, “O desenvolvimento do direito tradicional sob o impacto do direito moderno e vice-versa é o resultado de dois sistemas jurídicos operacionalmente fechados desenvolvendo-se simultaneamente" (BÄLZ, 1995, p. 42, tradução livre). Em outras palavras, cada ordem jurídica mantém-se no ambiente da outra e aberta cognitivamente (para Bälz) ou normativamente (segundo a tese do transconstitucionalismo) para o aprendizado recíproco. O caso Muhammad 'Ali Wasil v. o Ministro da Educação, avaliado no tópico anterior deste trabalho, ilustra a reconstrução, no interior da ordem estatal, dos princípios do direito islâmico. Em contrapartida, a teoria geral

alertou na nota de rodapé n. ${ }^{\circ} 12$. Espera-se tão-somente oferecer um diagnóstico sobre a evolução social e sobre os desafios da modernidade nessa região. A pesquisa que subsidia este trabalho sugere que a modernidade e a tradição convivem em relação de tensão e o desafio constitucional principal consiste em mediar essa complexidade. Ao mesmo tempo em que instituições religiosas antigas como a Universidade al-Azhar mantém alguns privilégios (cf. artigo $7^{\circ}$ da constituição egípcia, que garante independência e suporte financeiro a essa entidade), manifestações políticas de uma juventude cosmopolita em prol das liberdades civis, como as que se viram no Irã em 2009 ou na Tunísia e no Egito em 2011, mostram o lado moderno que também se verifica na região. Por isso, mais do que uma descrição das sociedades existentes nos países do mundo islâmico contemporâneo, a afirmação consiste em uma chave-de-leitura para os problemas constitucionais associados ao papel da religião na construção de uma ordem jurídico-constitucional capaz de coordenar ações sociais legitimamente.

128 A premissa de que o direito islâmico é um sistema operativamente fechado e cognitivamente aberto não é inteiramente correta, visto que as expectativas normativas e cognitivas não se diferenciam completamente. 
dos contratos do jurista árabe al-Sanhuri, de acordo com Bälz (1995, p. 49-50), representa um aprendizado do direito islâmico a partir das comunicações em seu ambiente.

Essas considerações no campo da teoria constitucional somam-se à avaliação anterior dos casos para mostrar que a possibilidade de conversações constitucionais entre o direito islâmico e outras ordens jurídicas existentes na sociedade mundial não é uma ilusão, mas talvez a estratégia mais promissora de fortificação das expectativas normativas nas sociedades dos países do mundo islâmico.

No último tópico deste trabalho, pretende-se discutir, ainda que sem a profundidade que o tema mereceria, em que medida os protestos que aconteceram no Oriente Médio e no Norte da África entre os anos de 2010 e 2012 apresentam o potencial de superação da tradição e um movimento em direção à constituição em sentido moderno, que reconheça direitos fundamentais e aceite a limitação e o controle jurídico dos detentores do poder.

\subsection{A construção contínua de programas culturais e as perspectivas a partir da chamada "Primavera Árabe"}

Entre dezembro de 2010 e meados do ano de 2011, uma onda de protestos chacoalhou os países do mundo islâmico e ficou conhecida como "Primavera Árabe". Manifestações começaram na Tunísia e espalharam-se rapidamente por outros países do Oriente Médio e do Norte da África, provocando a deposição de ditadores longevos em quatro países: na Tunísia, Zine El-Abidine Ben Ali caiu após quase vinte e quatro anos no poder; no Egito, Hosni Mubarak foi forçado a renunciar depois de trinta anos como presidente; na Líbia, Muammar Kadafi foi morto por rebeldes após ter governado o país por quarenta e dois anos; finalmente, no Iêmen, Ali Abdullah Saleh fugiu para a Arábia Saudita, deixando a presidência depois de aproximadamente trinta e três anos.

Manifestações de dissídio político com a dimensão que tiveram os protestos da

Primavera Árabe não se originam de um único episódio que gera comoção, mas de um período razoavelmente longo de acumulação de insatisfações compartilhadas, seja com a falta de liberdade no contexto de países submetidos a regimes políticos autoritários, seja com o desemprego, a pobreza e a ausência de padrões mínimos de bem-estar social.

De todo modo, a maior parte das agências de notícias e dos autores que estudaram esses acontecimentos identifica o momento de ignição dos protestos na autoimolação de Mohamed Bouazizi, um morador de Sidi Bouzid, uma cidade pequena da Tunísia (CASTELLS, 2013, sem paginação). Em 17 de dezembro de 2010, ele ateou fogo ao próprio corpo, como 
forma de protesto após ter sido agredido fisicamente e humilhado pela polícia e pelas autoridades governamentais enquanto se debatia contra uma propina que lhe era exigida por inspetores locais para não confiscarem sua banca de frutas. A autoimolação foi registrada em vídeo e difundida por meio da Internet. Quando Mohamed Bouazizi morreu, em 4 de janeiro de 2011, manifestações cada vez maiores já se espraiavam por várias cidades do país. Em 14 de janeiro de 2011, o ditador Zine El-Abidine Ben Ali fugiu para a Arábia Saudita.

No Egito, assim como na Tunísia, houve um incidente mencionado com certa frequência como fator de ignição dos protestos. Em 10 de junho de 2010, Wael Ghonim, um executivo local do Google, criou uma página no Facebook intitulada "We Are All Khaled Said" ("Nós Somos Todos Khaled Said”, em tradução livre), em referência a um jovem blogueiro que a polícia espancou até a morte por ter exposto sua corrupção e criticado o regime de Hosni Mubarak. Não obstante a importância que essa página no Facebook viria a adquirir para a organização dos protestos de rua, segundo Castells, "a verdadeira centelha que deflagrou a revolução egípcia, incitando protestos numa escala sem precedentes, inspirou-se na revolução tunisiana, que acrescentou essa esperança à indignação provocada pela insuportável brutalidade" (CASTELLS, 2013, sem paginação). No Egito, em 11 de fevereiro de 2011, Hosni Mubarak, acuado e sem o apoio das Forças Armadas, renunciou.

À queda desses regimes autoritários teve de se seguir um momento de construção ou de reforma institucional e de restabelecimento da legitimidade estatal. Por isso, tanto a Tunísia quanto o Egito adotaram textos constitucionais novos. Outros países, como o Marrocos, por exemplo, realizaram reformas que propiciaram maior abertura para a participação popular e instituíram políticas públicas de bem-estar social para atender a determinadas demandas dos manifestantes. Mesmo assim, a dúvida sobre as implicações da Primavera Árabe e sobre seu significado para o direito constitucional nesses países ainda perdura.

Para Bryan S. Turner, a eleição de islamitas, tanto na Tunísia quanto no Egito, frustrou a expectativa de estabilização de um movimento democrático genuinamente popular e essencialmente secular (TURNER, 2012, p. 8). No caso egípcio, depois do anúncio da renúncia de Mubarak, quem assumiu o poder não foi o Presidente da Assembleia do Povo, como o artigo 84 da constituição previa, mas o Conselho Supremo das Forças Armadas (CSFA), "um conclave de vinte oficiais militares seniores liderados pelo Ministro da Defesa" (BROWNLEE; MASOUD; REYNOLDS, 2015, p. 104, tradução livre).

Em 06 de fevereiro de 2011, o CSFA instituiu um comitê de oito membros para emendar a constituição egípcia, formado principalmente por membros do establishment jurídico: integrantes da Suprema Corte Constitucional, bem como professores de direito das 
Universidades do Cairo e de Alexandria. O CSFA entregou a direção do comitê a um intelectual islamita chamado Tariq al-Bishri, o que, somando-se ao fato de que o único representante formalmente vinculado a um partido pertencia aos quadros da Irmandade Muçulmana, sugere que os militares pretendiam um arranjo no qual dividissem o poder com os islamitas (BROWNLEE; MASOUD; REYNOLDS, 2015, p. 108), não para promover um modelo de transição pactuada, ${ }^{129}$ mas possivelmente visando a manter o equilíbrio de poder que desde a presidência de Anwar al-Sadat caracteriza a política egípcia, em que os militares governavam fazendo concessões pontuais a demandas dos grupos islamitas para apaziguar sua oposição.

O mandato conferido a esse comitê requeria a adoção das emendas que "reputasse necessárias para assegurar a democracia e a justiça das eleições para a presidência da república" (BROWNLEE; MASOUD; REYNOLDS, 2015, p. 108, tradução livre). Em duas semanas, nove emendas foram escritas, entre as quais se destaca aquela que alterou o artigo 189 da constituição para determinar que um novo texto constitucional fosse escrito por um comitê de cem membros escolhidos pelo parlamento eleito, posteriormente aprovadas em referendo popular realizado no dia 09 de março de 2011. Esse resultado foi interpretado como um sinal de força da Irmandade Muçulmana, dado que já se esperava a sua vitória nas eleições parlamentares que se seguiriam às emendas constitucionais.

Em junho de 2011, vinte e oito partidos políticos, liderados pela Irmandade Muçulmana, coligaram-se em uma "Aliança Democrática", com o objetivo de disputar as eleições de acordo com uma lista unificada. Entretanto, diferenças ideológicas começaram a emergir, levando os não-islamitas a pedirem que o Conselho Supremo das Forças Armadas estabelecesse "princípios supraconstitucionais" "que limitassem a capacidade dos islamitas de criarem uma constituição teocrática. [Por exemplo,] Muhammad ElBaradei propôs adotar uma Carta de Direitos [Bill of Rights] antes que a constituição fosse escrita" (BROWNLEE; MASOUD; REYNOLDS, 2015, p. 109, tradução livre). Tanto os islamitas quanto os grupos seculares, à medida que a competição eleitoral foi se exacerbando, passaram a reconhecer o CSFA como um árbitro neutro na sua disputa, "ao invés do último vestígio do regime que eles lutaram para arrancar pela raiz" (BROWNLEE; MASOUD; REYNOLDS, 2015, p. 110, tradução livre). Porém, os islamitas rejeitavam a ideia dos princípios supraconstitucionais, assim como as disposições do documento divulgado pelo CSFA em novembro de 2011 "que

\footnotetext{
${ }^{129}$ De acordo com Michel Rosenfeld (2005, p. 18, tradução livre), "O modelo de transição pactuada envolve a passagem de um regime autoritário pré-constitucional a uma democracia constitucional por meio da negociação entre membros do regime autoritário ou seus herdeiros e reformadores que busquem a transição para a democracia."
} 
tentavam atar as mãos do futuro parlamento especificando a composição precisa do conselho que iria escrever a constituição" (BROWNLEE; MASOUD; REYNOLDS, 2015, p. 111, tradução livre), determinando que apenas vinte membros seriam nomeados pelo parlamento.

Finalmente, as eleições foram realizadas entre 28 de novembro de 2011 e 11 de janeiro de 2012. Somando-se os votos recebidos e as vagas conquistadas pela coligação liderada pelo Partido da Liberdade e da Justiça (PLJ), vinculado à Irmandade Muçulmana, com aqueles alcançados pela Aliança Islâmica, liderada pelo Partido da Luz, estabelecido pela Sociedade de Pregação Salafita, os islamitas obtiveram aproximadamente $70 \%$ dos assentos no parlamento. O presidente eleito Mohamed Morsi reduziu os poderes políticos do Conselho Supremo das Forças Armadas, cancelando a declaração constitucional que lhes atribuía o exercício dos poderes executivo e legislativo e assumindo, ele próprio, essas competências.

A assembleia constituinte finalizou um projeto de constituição em 29 de novembro de 2012, depois que muitos de seus membros mais liberais abandonaram os trabalhos e foram substituídos por pessoas ligadas ao islamismo. O texto constitucional foi aprovado pela população por meio de referendo realizado em dezembro do mesmo ano, "permitindo à Irmandade Muçulmana reclamar uma maioria saudável” (BROWNLEE; MASOUD; REYNOLDS, 2015, p. 123, tradução livre). O artigo 219 do texto constitucional de 2012 buscava superar a abordagem modernizante da Suprema Corte Constitucional do Egito no caso Muhammad 'Ali Wasil v. o Ministro da Educação em favor de uma compreensão tradicionalista do direito islâmico (LOMBARDI; BROWN, 2012, sem paginação).

Entretanto, a nova constituição não foi suficiente para aplacar a disputa entre islamitas e seculares, nem para garantir legitimidade eleitoral a Mohamed Morsi. Protestos contra o governo democraticamente eleito aconteceram em 30 de junho de 2013, pedindo a renúncia imediata do presidente islamita. Segundo Arafa (2014, p. 866), a preocupação principal era a de que Morsi estivesse gradualmente promovendo uma agenda de islamização tendente ao totalitarismo, desconsiderando a oposição liberal e o Estado de Direito.

Em 03 de julho de 2013, o ministro da defesa Abdel Fattah Al-Sisi - "cercado por alguns dos líderes políticos e religiosos mais proeminentes do Egito - anunciou que o primeiro presidente democraticamente eleito do Egito 'falhara em atingir e conformar-se às demandas do povo,' e fora removido do cargo" (BROWNLEE; MASOUD; REYNOLDS, 2015, p. 125, tradução livre). Os militares colocaram o presidente da Suprema Corte Constitucional do Egito à frente do governo, até que eleições presidenciais pudessem ser realizadas. Mohamed A. Arafa chama esse evento de um "golpe popular" (ARAFA, 2014, p. 876-877), porque "a remoção de Morsi do cargo foi o resultado do livre arbítrio dos egípcios, não de um golpe de Estado militar" 
(ARAFA, 2014, p. 867, tradução livre). Houve a suspensão da constituição de 2012 e a elaboração de um texto constitucional novo, que um referendo aprovou em 2014 e que permanece em vigência no país atualmente.

De acordo com Martin Loughlin, a democracia orienta-se para o futuro, enquanto o direito orienta-se para o passado - e é nesta relação de tensão que o poder constituinte surge como conceito por meio do qual se realiza a mediação entre a inovação e a conservação (LOUGHLIN, 2003, p. 113). Perfilhando linha de raciocínio semelhante, Michel Rosenfeld aduz que "elaboração de constituição requer tanto a negação de identidades pré-constitucionais quanto a criação de uma nova identidade que requer a reincorporação de material do passado pré-constitucional" (ROSENFELD, 2005, p. 12, tradução livre).

Após os levantes árabes que se iniciaram em dezembro de 2010, o constitucionalismo recebeu um impulso (SATER, 2013, p. 2). O caso do Egito é exemplificativo do modo como os princípios do majoritarianismo e as ideias do direito islâmico entraram em conflito com aquilo que se denominou "princípios supraconstitucionais" de proteção dos direitos fundamentais por meio de leis seculares.

Bryan Turner explica a eleição de Mohamed Morsi, uma liderança da Irmandade Muçulmana, aludindo à força de que essa organização goza no interior no país. Para ele, os protestos na Praça Tahrir não eram representativos de toda a comunidade egípcia, "especialmente o interior onde o campesinato conservador forma a massa da população" (TURNER, 2012, p. 11, tradução livre). Contudo, o problema talvez seja melhor compreendido a partir da relação de convergência que se instalou entre a identidade constitucional e a identidade extraconsitucional prevalentemente muçulmana após a queda do regime autoritário de Hosni Mubarak no Egito: o Islã foi, historicamente, "uma limitação ao poder estatal secular e uma fonte de resistência contra o governo impopular ou injusto" (SATER, 2013, p. 3, tradução livre). Desse modo, após a deposição de um ditador, não foi constitucionalismo de matriz ocidental, caracterizado pela crença no Estado de Direito e na vinculação dos poderes constituídos à soberania da vontade popular expressa na lei (LOUGHLIN, 2003, p. 44-47), mas a tradição da lei islâmica que surgiu como alternativa àquela forma de autoritarismo, que antes se justificava perante a comunidade internacional valendo-se da suposta necessidade de controlar, por meio da força militar em última análise, o fundamentalismo islâmico.

Os protestos contra o governo democraticamente eleito de Mohamed Morsi são ilustrativos da falta de credibilidade nos procedimentos eleitorais constitucionalmente previstos como instituidores de legitimidade política. Apesar disso, não representaram uma rejeição ao pano de fundo ideológico do islamismo. Tanto é assim que o ministro da defesa Al-Sisi incluiu 
o Grande Imã da universidade Al Azhar, principal autoridade em matéria religiosa muçulmana, no anúncio da remoção de Morsi do cargo. É a conjunção da força militar com a legitimidade religiosa que se estabeleceu como fonte de confiança. Na opinião de James Sater (2013):

"[...] isso demonstra as dificuldades que a transição egípcia do governo autoritário está atualmente enfrentando; a referência abstrata ao constitucionalismo está sendo erodida por referências historicamente calcadas ao direito islâmico que impuseram padrões de proteção e de controle além do majoritarianismo e dos direitos constitucionais, i.e. leis humanas. Esses padrões coexistem com medos liberais sobre o majoritarianismo, especialmente aqueles com tendências autoritárias. Nesse caso, Exército, líderes religiosos e oposição secular formaram uma aliança profana, sustentada pelo grupo salafista mais radical al-Nour, contra a presidência do PLJ” (SATER, 2013, p. 5-6, tradução livre).

Nesse quadro de referências, a Primavera Árabe não provocou o poder constituinte como ruptura com o passado, nem desencadeou processos de integração social. Apesar disso, os protestos que levaram à queda de regimes autoritários e do governo de Mohamed Morsi revelam a resistência em relação às formas tradicionais de legitimação do poder político no Oriente Médio e no Norte da África. Por isso, ilustram a construção contínua de programas culturais que podem renovar o saber eficaz em termos de legitimação. 


\section{CONCLUSÃO}

O direito islâmico é uma ordem jurídica de matriz religiosa, que se desenvolve principalmente por meio da ciência do direito ou fiqh. O processo por meio do qual os juristas muçulmanos extraem regras a partir das fontes chama-se ijtihad e determinou a evolução do direito islâmico nos séculos iniciais do Islã. A teoria do direito (usūl al-fiqh) reconhece quatro fontes ou raízes: o Corão, a sunna do profeta Maomé, o ijmā (consenso) e o qiyās (analogia). Após o período formativo, houve a consolidação de quatro escolas doutrinárias do rito sunita e o suposto fechamento dos portões da ijtihad. Após a invasão dos mongóis a Bagdá, tem início um período de governo por líderes militares de comunidades locais. Estudiosos muçulmanos criam a teoria da siyāsa shar 'iyya, de acordo com a qual o poder do governante é limitado pelas regras e pelos objetivos da sharī'a, mas discricionário quanto ao mais.

Pode-se dividir a história constitucional dos países do mundo islâmico em cinco fases para fins analíticos. A primeira caracteriza-se pela expansão saudita com base ideológica no wahabismo, um movimento fundamentalista que visava a recuperar uma teoria tradicional do Estado islâmico. A segunda fase encontra seu marco inicial no colapso do Império Otomano. Nela, ocorre a imposição de modelos constitucionais ocidentais e o surgimento de nacionalismos locais. A terceira é caracterizada pelo projeto pan-arabista de Gamal Nasser. Com a derrota militar para Israel na guerra de 1967, esse projeto chega ao fim e a quarta fase tem início, com uma volta do nacionalismo local e do fundamentalismo islâmico. A quinta e última fase começa com a Revolução Iraniana e compreende as reações a ela no mundo sunita, inclusive a afirmação de regimes autoritários por meio do estado de emergência.

A codificação do direito a partir do Século XIX e o conceito de Estado-nação implicam disputas internas pela adoção da sharī’a pelas ordens jurídicas nacionais. Sob o ponto de vista religioso, o secularismo é inaceitável, porque configura uma forma de dominação cultural ocidental. Esses fatores confluem para limitar a possibilidade de eficácia do direito fundamental à liberdade religiosa nos países do mundo islâmico.

Entre os casos que este trabalho avalia, há exemplos de conversação constitucional e de recusa ao envolvimento. Eles permitem um diagnóstico sobre os limites e as possibilidades do constitucionalismo quando uma das ordens jurídicas envolvidas é a sharī'a ou o direito islâmico. Nos países em que a constituição estabelece um vínculo estrutural entre a ordem estatal e a sharì'a, o limite ao transconstitucionalismo é a falta de disposição para suportar um comportamento diferente daquele que ele próprio havia projetado, tendo em conta que no direito 
islâmico o mutável permanece subordinado ao imutável, e a ausência de procedimentos constitucionais de absorção do dissenso.

Em contrapartida, nos países ocidentais o limite do transconstitucionalismo em relação à sharī'a é a desconfiança, que dificulta interações fundadas na observação recíproca.

Mesmo assim, o transconstitucionalismo apresenta um método promissor para solução de problemas constitucionais nos países do mundo islâmico, porque possibilita desenvolvimento de institutos que possam levar a uma relação construtiva de aprendizado mesmo quando uma das ordens jurídicas não está inteiramente comprometida com a constituição em sentido moderno.

A Primavera Árabe não representou uma ruptura com o passado nem inaugurou um momento de transição constitucional, mas as revoltas revelaram a convivência entre a tradição islâmica e tendências modernizantes na sociedade dos países árabes. A construção contínua de programas culturais é necessária para a renovação do estoque de saber necessário à coordenação de ações de acordo com uma ordem legítima. 


\section{REFERÊNCIAS BIBLIOGRÁFICAS}

ACKERMAN, Elliot. Atatürk versus Erdogan: Turkey's long struggle. The New Yorker, 16 jul. 2016. Disponível em: <http://www.newyorker.com/news/news-desk/ataturk-versuserdogan-turkeys-long-struggle>. Acesso em: 16 jul. 2016.

AFSAH, Ebrahim. Contested Universalities of International Law: Islam's Struggle with Modernity. In: Journal of the History of International Law, v.10, p. 259-307, 2008. Disponível em: http://papers.ssrn.com/sol3/Delivery.cfm/SSRN_ID2373747_code2165049.pdf?abstractid=23 73747\&mirid=1. Acesso em: 05 mai. 2016.

AL-HIBRI, Azizah Y. Islamic and American Constitutional Law: Borrowing Possibilities or a History of Borrowing Contextuality \& Universality: Constitutional Borrowings on the Global Stage. In: University of Pennsylvania Journal of Constitutional Law, v.1, p. 492-527, 1998.

AN-NA'IM, Abdullahi A. Complementary, Not Competing, Claims of Law and Religion: An Islamic Perspective. In: Pepperdine Law Review, v.39, p. 1231-1256, 2011.

ARAFA, Mohamed A. Whither Egypt: Against Religious Fascism and Legal Authoritarianism: Pure Revolution, Popular Coup, Or a Military Coup d'Etat? In: Indiana International \& Comparative Law Review, v.24, n.4, p. 859-898, 2014.

Case No. 8 of Judicial Year 17, May 18, 1996 (Egypt). Max Planck Encyclopedia of Constitutional Law: Manuscrito cedido pelo autor. 2016 (No prelo).

ARJOMAND, Saïd Amir. The Kingdom of Juristis: Constitutionalism and the legal order in Iran. In: GROTE, Rainer; RÖDER; Tilmann J. (org.). Constitutionalism in Islamic countries. Oxford: Oxford University Press, 2012, p.147-169

AYDINLI, Ersel. A Paradigmatic Shift for the Turkish Generals and an End to the Coup Era in Turkey. In: The Middle East Journal, v.63, n.4, p. 581-596, 2009. Disponível em: http://ersel.bilkent.edu.tr/Makaleler/a_paradigmatic_shift_for_the_turkish_generals_and_an_e nd_to_the_coup_era_in_turkey.pdf. Acesso em: 29 jul. 2016.

BÄLZ, Kilian. Shari'a and Qanun in Egyptian Law: A System's Theory Approach to Legal Pluralism. In: Yearbook of Islamic and Middle Eastern Law, v.2, p. 37-53, 1995.

The secular reconstruction of Islamic law: The Egyptian Supreme Constitutional Court and the "battle over the veil" in state-run schools. In: DUPRET, Baudouin; BERGER, Maurits; AL-ZWAINI, Laila (org.). Legal pluralism in the Arab World. Hague: Kluwer Law International, 1999, p.229-243

BASSIOUNI, M. Cherif; BADR, Gamal Moursi. The Shari'ah: Sources, Interpretation, and Rule-Making. In: UCLA Journal of Islamic and Near Eastern Law, v.1, p. 135-178, 2002.

BENSON, Kristina. Shar'ia Law and the Accommodation of Difference: Explaining the Emergence and Continued Importance of the British Shar'ia Councils. In: UCLA Journal of Islamic and Near Eastern Law, v.11, p. 21-36, 2011. 
BROWN, Nathan J. Constitutions in a nonconstitutional world: Arab basic laws and the prospects for accountable government. Albany: State University of New York Press, 2002.

BROWN, Nathan J.; LOMBARDI, Clark B. The Supreme Constitutional Court of Egypt on Islamic Law, Veiling and Civil Rights: An Annotated Translation of Supreme Constitutional Court of Egypt Case No. 8 of Judicial Year 17 (May 18, 1996). In: American University International Law Review, v.21, n.3, p. 437-460, 2006. Disponível em: http://digitalcommons.wcl.american.edu/cgi/viewcontent.cgi?article=1055\&context=auilr. Acesso em: 01 mai. 2015.

BROWNLEE, Jason; MASOUD, Tarek; REYNOLDS, Andrew. The Arab Spring: Pathways of repression and reform. Oxford: Oxford University Press, 2015.

BURTON, John. The sources of Islamic law: Islamic theories of abrogation. Edinburgh: Edinburgh University Press, 1990.

An introduction to the Hadīth. Edinburgh: Edinburgh University Press, 1994.

CASSESE, Sabino. A crise do Estado. Trad. Ilse Paschoal Moreira e Fernanda Landucci Ortale. Campinas: Saberes, 2010.

CASTELLS, Manuel. Redes de indignação e esperança: movimentos sociais na era da internet. Rio de Janeiro: Zahar, 2013. Livro eletrônico não paginado.

CHRISTOFFERSEN, Lisbet. Is Shari'a Law, Religion or a Combination? European legal discourses on shari'a. In: NIELSEN; Jørgen S.; CHRISTOFFERSEN, Lisbet (org.). Shari'a as discourse: Legal traditions and the encounter with Europe. Farnham: Ashgate, 2010, p.5775

COOK, Michael. The Koran: A very short introduction. Oxford: Oxford University Press, 2000 .

CORTE EUROPEIA DE DIREITOS HUMANOS. Grand Chamber. Case of Refah Partisi (The Welfare Party) and others v. Turkey, julgado em 13 fev. 2003. Disponível em http://hudoc.echr.coe.int/eng?i=001-60936. Acesso em: 8 jul. 2016.

COULSON, Noel J. A history of islamic law. Edinburgh: Edinburgh University Press, 1964.

DAVID, René. Os grandes sistemas do direito contemporâneo. Trad. Hermínio A. Carvalho. 2. ed. São Paulo: Martins Fontes, 1993.

DORSEN, Norman et al. Comparative constitutionalism: cases and materials. 2. ed. St. Paul: Thomson/West, 2010.

EL FADL, Khaled Abou. The centrality of sharīah to government and constitutionalism in Islam. In: GROTE, Rainer; RÖDER; Tilmann J. (org.). Constitutionalism in islamic countries. Oxford: Oxford University Press, 2012, p.35-61 
EL SAWY, Maria Izabel Sales de França. A shari'ah al islamia: Contextualização histórica, política e atualidade. 2002. Tese (Doutorado em Direito). Centro de Ciências Jurídicas, Universidade Federal de Pernambuco, Recife.

EMON, Anver. Reflections on the Constitution of Medina: An Essay on Methodology and Ideology in Islamic Legal History. In: UCLA Journal of Islamic and Near Eastern Law, v.1, p. [i]-134, 2001.

ESTADOS UNIDOS. Suprema Corte. Reynolds v. United State, julgado em 06 jan. 1879. Disponível em: 〈https://www.law.cornell.edu/supremecourt/text/98/145>. Acesso em: 11 maio 2016.

Suprema Corte. Lanzetta v. New Jersey, julgado em 27 mar. 1939. Disponível em <http://www.lexisnexis.com/lnacui2api/api/version1/getDocCui?ni=3S4X-82D0-003B$745 \mathrm{~N} \& \mathrm{csi}=6496 \& \mathrm{hl}=\mathrm{t} \& \mathrm{hv}=\mathrm{t} \& \mathrm{hnsd}=\mathrm{f} \& \mathrm{hns}=\mathrm{t} \& \mathrm{hgn}=\mathrm{t} \& \mathrm{oc}=00240 \&$ perma $=$ true $>$. Acesso em: 18 maio 2016.

Suprema Corte. Cantwell v. Connecticut, julgado em 20 maio 1940. Disponível em: $\overline{<h t t p s: / / w w w . l a w . c o r n e l l . e d u / s u p r e m e c o u r t / t e x t / 310 / 296>. ~ A c e s s o ~ e m: ~} 07$ maio 2016.

Suprema Corte. Cox v. New Hampshire, julgado em 31 mar. 1941. Disponível em: http://www.lexisnexis.com/lnacui2api/api/version1/getDocCui?oc=00240\&hnsd=f\&hgn=t\&ln $\mathrm{i}=3 \mathrm{~S} 4 \mathrm{X}-67 \mathrm{R} 0-003 \mathrm{~B}-$

$70 \mathrm{YH} \& \mathrm{hns}=\mathrm{t} \&$ perma $=$ true $\& \mathrm{hv}=\mathrm{t} \& \mathrm{hl}=\mathrm{t} \& \mathrm{csi}=6496 \&$ secondRedirectIndicator $=$ true. $\quad$ Acesso em: 12 maio 2016.

Suprema Corte. Hamilton et al. v. Regents of the University of California, julgado em 03 dez. $1934 . \quad$ Disponível em: <http://www.lexisnexis.com/lnacui2api/api/version1/getDocCui?lni=3S4X-BJ50-003B$704 \mathrm{~V} \& \mathrm{csi}=6496 \& \mathrm{hl}=\mathrm{t} \& \mathrm{hv}=\mathrm{t} \& \mathrm{hnsd}=\mathrm{f} \& \mathrm{hns}=\mathrm{t} \& \mathrm{hgn}=\mathrm{t} \& \mathrm{oc}=00240 \&$ perma $=$ true $>$. Acesso em: 12 mai. 2016i=3S4X-67R0-003B$70 \mathrm{YH} \& \mathrm{hns}=\mathrm{t} \&$ perma $=$ true $\& \mathrm{hv}=\mathrm{t} \& \mathrm{hl}=\mathrm{t} \& \mathrm{csi}=6496 \&$ secondRedirectIndicator $=$ true $>$. Acesso em: 12 maio 2016.

1926.

Suprema Corte. Connally v. General Construction Company, julgado em 04 jan. <http://www.lexisnexis.com/lnacui2api/api/version1/getDocCui?lni=3S4X-GW30-003B$70 \mathrm{PN} \& \mathrm{csi}=6496 \& \mathrm{hl}=\mathrm{t} \& \mathrm{hv}=\mathrm{t} \& \mathrm{hnsd}=\mathrm{f} \& \mathrm{hns}=\mathrm{t} \& \mathrm{hgn}=\mathrm{t} \& \mathrm{oc}=00240 \&$ perma $=$ true $>$. Acesso em: 18 maio 2016.

District Court for the Western District of Oklahoma. Awad v. Ziriax, julgado em 9. nov. 2010. Disponível em: http://www.lexisnexis.com/lnacui2api/api/version1/getDocCui?lni=51KH-CK11-652J$\mathrm{G} 005 \& \mathrm{csi}=6496 \& \mathrm{hl}=\mathrm{t} \& \mathrm{hv}=\mathrm{t} \& \mathrm{hnsd}=\mathrm{f} \& \mathrm{hns}=\mathrm{t} \& \mathrm{hgn}=\mathrm{t} \& \mathrm{oc}=00240 \&$ perma=true. Acesso: 22 jul. 2016.

Disponível

Court of Appeals for the Tenth Circuit. Awad v. Ziriax, julgado em 10 jan. 2012. $<$ http//www lexisnexis.com/lnacui2api/delivery/DownloadDoc.do?delFmt=QDS_EF_PDF\&f ileSize $=5000 \&$ dnldFilePath $=\% 2$ Fl- 
n $\% 2$ Fshared $\% 2$ Fprod $\% 2$ Fdiscus $\% 2 F q d s \% 2 F r e p o s i t o r y \% 2 F d o c s \% 2 F 5 \% 2 F 83 \% 2 F 2827 \% 3 \mathrm{~A} 5$ 71462835\%2Fformatted_doc\&zipDelivery $=$ false \&dnldFileName=670_F.3d_1111\%2C_2012 _U.S._App._LEXIS_475\%2C_\&jobHandle=2827\%3A571462835>. Acesso em: 22 jul. 2016.

FELDMAN, Noah. The fall and rise of the Islamic State. Princeton: Princeton University Press, 2008.

GAMBARO, Antonio; SACCO, Rodolfo. Sistemi giuridici comparati. 3. ed. Torino: UTET Giuridica, 2013.

GILISSEN, John. Introdução histórica ao direito. Trad. Antonio Manuel Hespanha e L. M. Macaísta Malheiros. 5. ed. Lisboa: Fundação Calouste Gulbenkian, 2008 [1979].

GLENN, H. Patrick. Persuasive authority. In: McGill Law Journal, v.32, n.2, p. 261-298, 1987. Disponível em: http://lawjournal.mcgill.ca/userfiles/other/5408801-glenn.pdf. Acesso em: 19 jan. 2016.

Legal traditions of the world. 5. ed. Oxford: Oxford University Press, 2014.

GOOLAM, Nazeem MI. Ijtihad and Its Significance for Islamic Legal Interpretation. In: Mich. St. L. Rev., v.2006, p. 1443-1468, 2006.

GRIM, Brian J.; FINKE, Roger. The price of freedom denied: Religious persecution and conflict in the 21st century. New York: Cambridge University Press, 2011.

GRUNERT, Jeremy. How Do You Solve a Problem Like Sharia? Awad v. Ziriax and the Question of Sharia Law in America. In: Pepperdine Law Review, v.40, n.3, p. 695-734, 2013.

GULALP, Haldun. Political Islam in Turkey: The rise and fall of the Refah Party. In: The Muslim World, v.89, n.1, p. 22-41, Jan 1999 1999. Disponível em: http://search.proquest.com/docview/216360617? accountid=26646

http://link.periodicos.capes.gov.br/sfxlc141?url_ver=Z39.88-

2004\&rft_val_fmt=info:ofi/fmt:kev:mtx:journal\&genre=article\&sid=ProQ:ProQ\%3Apqrl\&ati tle $=$ Political+Islam+in+Turkey\%3A+The+rise+and+fall + of + the + Refah + Party \& title $=$ The $+\mathrm{Mu}$ slim+World \&issn=00274909\&date=1999-01-

$01 \&$ volume $=89 \&$ issue $=1 \&$ spage $=22 \&$ au $=$ Gulalp $\% 2 \mathrm{C}+$ Haldun $\&$ isbn $=\&$ jitle $=$ The + Muslim + World\&btitle=\&rft_id=info:eric/\&rft_id=info:doi/.

HABERMAS, Jürgen. Direito e democracia: entre facticidade e validade. Trad. Flávio Beno Siebeneichler. v.1. Rio de Janeiro: Tempo Brasileiro, 2003.

Teoria do agir comunicativo: Racionalidade damação e racionalização social. Trad. Paulo Astor Soethe. v.1. São Paulo: Martins Fontes, 2012a.

Teoria do agir comunicativo: Sobre a crítica da razão funcionalista. Trad. Flávio Beno Siebeneichler. v.2. São Paulo: Martins Fontes, 2012b.

HALLAQ, Wael B. Was the gate of ijtihad closed? In: International Journal of Middle East Studies, v.16, n.1, p. 3-41, 1984. 
A history of islamic legal theories: An introduction to sunni usul al-fiqh. Cambridge: Cambridge University Press, 1997.

. Can the shari'a be restored? In: HADDAD, Yvonne Yazbeck; STOWASSER, Barbara Freyer (org.). Islamic law and the challenges of modernity. Walnut Creek: Altamira Press, 2004. Livro eletrônico não paginado.

An introduction to islamic law. Cambridge: Cambridge University Press, 2009.

HARASANI, Hamid. The role of ijtihad in progressing islamic law in modern times. In: USChina Law Review, v.10, p. 361-371, 2013.

HERTEL, Christian. Sintesi dei sistemi giuridici. In: Notarius International, n.1-2, p. 171$185,2009$.

HIRSCHL, Ran. Constitutional Courts vs. Religious Fundamentalism: Three Middle Eastern Tales. In: Texas Law Review, v.82, p. 1819-1860, 2004.

HOURANI, Albert. O pensamento árabe na era liberal: 1798-1939. Trad. Rosaura Eichenberg. São Paulo: Companhia das Letras, 2005.

Letras, 2006.

Uma história dos povos árabes. Trad. Marcos Santarrita. São Paulo: Companhia das

INGLATERRA. High Court of Justice-Chancery Division. J. Bollinger and Others v. The Costa Brava Wine Company Limited. R.P.C. 1961 78: 116-127. Disponível em: <http://rpc.oxfordjournals.org/content/78/5/116.full.pdf+html>. Acesso em: 07 maio 2016.

JACKSON, Vicki C. Constitutional Comparisons: Convergence, Resistance, Engagement. In: Harvard Law Review, v.119, n.1, p. 109-128, 2005.

JUYNBOLL, Theodor Willem. Manuale di diritto musulmano secondo la dottrina della scuola sciafeita. Trad. Giovanni Baviera. Milano: Francesco Vallardi, 1916.

KAMALI, Mohammad Hashim. Shari'ah Law: An introduction. Oxford: Oneworld, 2008.

Constitutionalism in Islamic countries: A contemporary perspective of Islamic law. In: GROTE, Rainer; RÖDER; Tilmann J. (org.). Constitutionalism in Islamic countries: Between upheaval and continuity. Oxford; New York: Oxford University Press, 2012, p.1933

KHADDURI, Majid. Nature and sources of islamic law. In: George Washington Law Review, v.22, p. 3-23, 1953-1954.

KHAN, Amjad Mahmood. Misuse and Abuse of Legal Argument by Analogy in Transjudicial Communication: The Case of Zaheeruddin v. State. In: Richmond Journal of Global Law and Business, v.10, p. 497-524, 2010.

KIM, Eun-Jung Katherine. Islamic Law in American Courts: Good, Bad, and Unsustainable Uses. In: Notre Dame Journal of Law, Ethics \& Public Policy, v.28, p. 287-308, 2014. 
KOÇAK, Mustafa. Islam and national law in Turkey. In: OTTO, Jan Michel (org.). Sharia incorporated: A comparative overview of the legal systems of twelve muslim countries in past and present. Leiden: Leiden University Press, 2010, p.231-272

LAGE, Leonardo Almeida; OLIVIERO, Maurizio. Interpretação das fontes e pluralismo jurídico no direito islâmico. In: Novos Estudos Jurídicos, v.21, n.1, p. 65-88, 2016. Disponível em: http://siaiap32.univali.br/seer/index.php/nej/article/view/8749/4878. Acesso em: 01 jun. 2016.

LAU, Martin. Islam and the Constitutional Foundations of Pakistan. In: GROTE, Rainer; RÖDER; Tilmann J. (org.). Constitutionalism in islamic countries: Between upheaval and continuity. Oxford: Oxford University Press, 2012, p.171-199

LEWIS, Bernard. A crise do Islã: Guerra santa e terror profundo. Trad. Maria Lúcia de Oliveira. Rio de Janeiro: Jorge Zahar, 2004.

LOCCHI, Maria Chiara; OLIVIERO, Maurizio. La circolazione della dottrina straniera nella giurisprudenza delle corti costituzionali dei paesi arabi: il caso libanese. Manuscrito cedido pelo autor. 2015.

LOMBARDI, Clark B.; BROWN, Nathan J. Do Constitutions Requiring Adherence to Shari'a Threaten Human Rights? How Egypt's Constitutional Court Reconciles Islamic Law with the Liberal Rule of Law. In: American University International Law Review, v.21, n.3, p. 379435, 2006.2 Disponível em: http://digitalcommons.wcl.american.edu/cgi/viewcontent.cgi? article=1054\&context=auilr. Acesso em: 16 mai. 2015.

Islam in Egypt's new constitution. In: Foreign Policy, p., 2012. Disponível em: http://ssrn.com/abstract=2258252. Acesso em: 24 mai. 2016.

LOUGHLIN, Martin. The ideia of public law. Oxford: Oxford University Press, 2003.

LOWRY, Joseph E. Does Shāfi'ì have a Theory of Four Sources of Law? In: WEISS, Bernard (org.). Studies in Islamic legal theory. v.15. Leiden; Boston; Köl: Brill, 2002, p.23-50

LUHMANN, Niklas. El derecho de la sociedad. Trad. Javier Torres Nafarrate. 2. ed. México: Herder; Universidad Iberoamericana, 2005.

La sociedad mundial. In: Estudios Sociológicos, v.24, n.72, p. 547-568, 2006.

MACCORMICK, Neil. Retórica e o estado de direito. Trad. Conrado Hübner Mendes. Rio de Janeiro: Elsevier, 2008.

MAHMUD, Tayyah. Freedom of Religion \&(and) Religious Minorities in Pakistan: A Study of Judicial Practice. In: Fordham International Law Journal, v.19, p. 40-100, 1995.

MARET, Rebecca E. The Equality Bill and Sharia Arbitration in the United Kingdom. In: Boston College International and Comparative Law Review, v.36, n.1, p. 255-283, 2013. Disponível 
http://lawdigitalcommons.bc.edu/cgi/viewcontent.cgi?article=1696\&context=iclr. Acesso em: 31 jul. 2016.

MELCHERT, Christopher. The formation of the sunni schools of law, 9th-10th centuries C.E. Leiden; New York; Kölin: Brill, 1997.

NEVES, Marcelo. A constitucionalização simbólica. São Paulo: WMF Martins Fontes, 2007. Transconstitucionalismo. São Paulo: Martins Fontes, 2009.

Entre Têmis e Leviatã: Uma relação difícil. 3. ed. São Paulo: Martins Fontes, 2012.

OLIVIERO, Maurizio. Il costituzionalismo dei paesi arabi. v.1. Milano: Giuffrè, 2003.

I paesi del mondo islamico. In: CARROZZA, Paolo; DI GIOVINE, Alfonso; FERRARI, Giuseppe F. (org.). Diritto costituzionale comparato. 2. ed. ed. v.1. Roma: Laterza, 2014, p.593-624

Democrazia e diritti nelle società multiculturali: verso una "democrazia costituzionale multiculturale". Manuscrito cedido pelo autor. s.d.-a. Sem paginação.

I sistemi giuridici comparati. Manuscrito cedido pelo autor (apontamentos para a disciplina "Sistemas jurídicos comparados e direito transnacional", ofertada como Atualização e Prática do Direito 1 para o curso de graduação em Direito da Universidade de Brasília, no segundo semestre de 2014). s.d.-b. Sem paginação.

Il diritto musulmano. Manuscrito cedido pelo autor. s.d.-c. p. 67-126.

OTTO, Jan Michel. The compatibility of sharia with the rule of law. Fundamental conflict: between civilisations? Within civilisations? Or between scholars? In: GROEN, Adriaan in 't; JONGE, Henk Jan de; KLASEN, Eduard et al. (org.). Knowledge in Ferment: Dilemmas in Science, Scholarship and Society. Leiden: Leiden University Press, 2007, p.137-154

PAQUISTÃO. Suprema Corte. Zaheerudin v. The State, julgado em 3 jul. 1993. Disponível em: http://thepersecution.org/archive/judgement/index.html. Acesso em: 29 abr. 2016.

PLANTIN, Christian. A argumentação: História, teorias, perspectivas. Trad. Marcos Marcionlino. São Paulo: Parábola, 2008.

REGLA, Josep Aguiló. Positivismo y postpositivismo: Dos paradigmas jurídicos en pocas palabras. In: DOXA, Cuadernos de Filosofía del Derecho, v.30, p. 665-675, 2007.

ROESLER, Claudia Rosane. Theodor Viehweg e a ciência do direito: Tópica, discurso, racionalidade. 2. ed. Belo Horizonte: Arraes, 2013.

ROSENFELD, Michel. The problem of identity in constitution-making and consistutional reform. 2005. Disponível em: http://papers.ssrn.com/sol3/papers.cfm?abstract_id=870437. Acesso em: 20 jul. 2015. 
SACCO, Rodolfo. Introdução ao direito comparado. Trad. Véra Jacob de Fradera. São Paulo: Revista dos Tribunais, 2001.

SATER, James. Egypt: Problems of Constitutionalism and Secularism. In: Center for Mellemøststudier, Syddansk Universitet, p. 1-7, set. 2013.

SCHACHT, Joseph. An introduction to Islamic law. Oxford: Clarendon Press, 1964.

Law and Justice. In: HOLT, P. M.; LAMBTON, Ann K. S.; LEWIS, Bernard (org.).

The Cambridge History of Islam. v.2B. Cambridge: Cambridge University Press, 2008, p.539-568

SCHILLING, David; SPADA, Paola. European Islamaphobia and Turkey - Refah Partisi (The Welfare Party) v. Turkey. In: Loy. L.A. Int'l \& Comp. L. Rev., v.26, p. 501-516, 2003.

SIDDIQ, M. Nadeem Ahmad. Enforced Apostasy: Zaheeruddin v. State and the Official Persecution of the Ahmadiyya Community in Pakistan. In: Law and Inequality: A Journal of Theory and Practice, v.14, p. 275-338, 1995.

Sharia law review to focus on fairness to UK women - Theresa May. BBC, 26 maio 2016. Disponível em:< http://www.bbc.com/news/uk-36388560>. Acesso: 31 jul. 2016.

SLAUGHTER, Ann-Marie. Judicial Globalization. In: Virginia Journal of International Law, v.40, n.4, p. 1103-1124, 2000.

A global community of courts. In: Harvard International Law Journal, v.44, n.1, p. 191-220, 2003.

STILT, Kristen. "Islam is the Solution": Constitutional Visions Of the Egyptian Muslim Brotherhood. In: Texas International Law Journal, v.46, p. 73-108, 2013. Disponível em: http://ssrn.com/abstract=1612482. Acesso em: 21 mai. 2016.

STONE, Geoffrey R. et al. Constitutional law. 6. ed. New York: Aspen Publishers, 2009.

TEUBNER, Gunther. The Two Faces of Janus: Rethinking Legal Pluralism. In: Cardozo Law Review, v.13, n.5, p. 1443-1462, 1992.

TOULMIN, Stephen E. Os usos do argumento. Trad. Reinaldo Guarany. 2. ed. São Paulo: Martins Fontes, 2006.

TURNER, Bryan S. Arab Citizenship: the Arab Spring and its Unintended Consequences. In: Sociología Histórica, n. 1, p. 5-27, 2012.

TURQUIA. Constituição (1982). Constituição da República da Turquia: adotada pela Assembléia Constituinte em 18 de outubro de 1982, referendada em 07 de novembro de 1982. Disponível em <https://global.tbmm.gov.tr/docs/constitution_en.pdf>. Acesso: 28 jul. 2016.

TUSHNET, Mark. The inevitable globalization of constitutional law. In: Hague Institute for the Internationalization of Law; Harvard Public Law Working Paper No. 09-06, p., 2008. Disponível em: http://ssrn.com/abstract=1317766. Acesso em: 14 jan. 2016. 
WATT, William Montgomery. Islamic fundamentalism and modernity. Abington: Routledge, 2013.

WEISS, Bernard. Interpretation in Islamic law: The theory of ijtihad. In: American Journal of Comparative Law, v.26, p. 199-212, 1977-1978.

ZUBAIDA, Sami. Law and Power in the Islamic World. London; New York: I.B. Tauris, 2003.

ZWEIGERT, Konrad; KÖTZ, Hein. An introduction to comparative law. Trad. Tony Weir. 3. ed. Oxford; New York: Oxford University Press, 1998. 